Florida International University FIU Digital Commons

FIU Electronic Theses and Dissertations

University Graduate School

3-4-2015

\title{
Consumer Perceptions of Sustainability in the Cruise Industry
}

Lindsay Marie Ackerman

lacke007@fiu.edu

DOI: $10.25148 /$ etd.FI15032119

Follow this and additional works at: https://digitalcommons.fiu.edu/etd

Part of the Hospitality Administration and Management Commons, and the Tourism and Travel Commons

\section{Recommended Citation}

Ackerman, Lindsay Marie, "Consumer Perceptions of Sustainability in the Cruise Industry" (2015). FIU Electronic Theses and Dissertations. 1911.

https://digitalcommons.fiu.edu/etd/1911

This work is brought to you for free and open access by the University Graduate School at FIU Digital Commons. It has been accepted for inclusion in FIU Electronic Theses and Dissertations by an authorized administrator of FIU Digital Commons. For more information, please contact dcc@fiu.edu. 


\title{
FLORIDA INTERNATIONAL UNIVERSITY
}

Miami, Florida

CONSUMER PERCEPTIONS OF SUSTAINABILITY IN THE CRUISE INDUSTRY

\author{
A thesis submitted in partial fulfillment of \\ the requirements for the degree of \\ MASTER OF SCIENCE \\ in \\ HOSPITALITY MANAGEMENT \\ by \\ Lindsay Marie Ackerman
}

2015 
To: Dean Mike Hampton

School of Hospitality and Tourism Management

This thesis, written by Lindsay Marie Ackerman, and entitled Consumer Perceptions of Sustainability in the Cruise Industry, having been approved in respect to style and intellectual content, is referred to you for judgment.

We have read this thesis and recommend that it be approved.

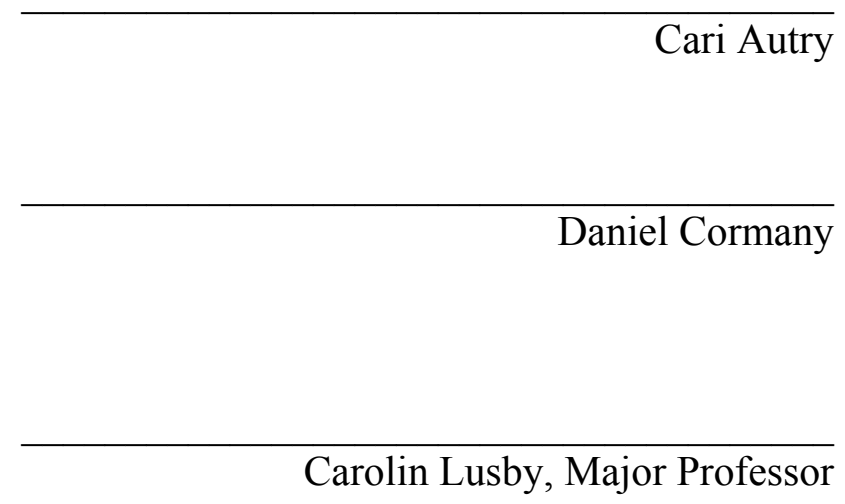

Date of Defense: March 4, 2015

The thesis of Lindsay Marie Ackerman is approved.

Dean Mike Hampton School of Hospitality and Tourism Management

Dean Lakshmi N. Reddi University Graduate School

Florida International University, 2015 


\section{DEDICATION}

To those who have inspired me 


\section{ACKNOWLEDGMENTS}

This thesis would not be possible without the guidance and encouragement of Dr. Carolin Lusby. Your confidence in my abilities helped push me to start and complete this process. If you had not encouraged me to study sustainability and to write about something important, this study would never have happened. Thank you for providing encouragement, support, and feedback. You have truly made going through this program worthwhile.

Besides my advisor, I would like to extend my sincere thanks to my thesis committee, Dr. Daniel Cormany and Dr. Cari Autry. I am grateful for the advice and feedback you provided to me. Your help and support for my thesis cannot be thanked enough.

I would also like to thank Seattle University for empowering me to become a better person. Your coursework helped guide me to the path I am following today. This was a time in my life that gave me new perspectives and further taught me about the injustices of the world.

Last but not least, I would like to express my profound gratitude to my parents Steven and Susan Ackerman. You have motivated me to continue my education and supported me during this roller coaster. You opened my eyes to the world and helped create my love of wanderlust. Thank you for giving me the tools to become the person I am today. 


\title{
ABSTRACT OF THE THESIS \\ CONSUMER PERCEPTIONS OF SUSTAINABILITY IN THE CRUISE INDUSTRY by
}

\author{
Lindsay Marie Ackerman
}

Florida International University, 2015

Miami, Florida

Professor Carolin Lusby, Major Professor

This thesis addresses the lack of available research regarding consumer perceptions of sustainability in the cruise industry. The study was conducted by administering an anonymous online survey with cruise message board participants and social media users. The survey was available to all consumers, including consumers who have not cruised. The survey focused on general reasons a consumer books a cruise, consumer travel behaviors, sustainability of the cruise industry, and sustainable factors that may impact a consumers' choice of a cruise line. The goal of this research was to determine any patterns and trends that may emerge regarding consumer perceptions. The findings of the study showed cruise history and demographics have influenced consumer views on sustainability in the cruise industry. 


\section{TABLE OF CONTENTS}

CHAPTER

PAGE

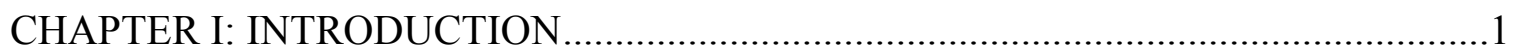

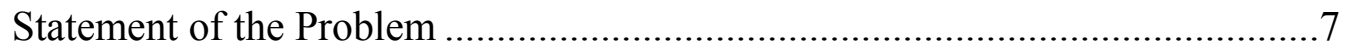

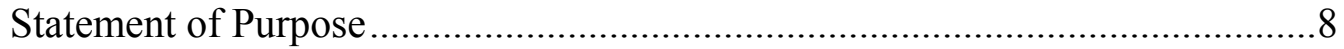

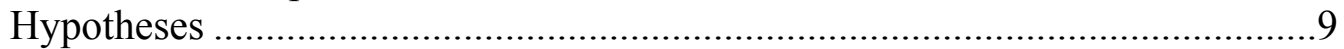

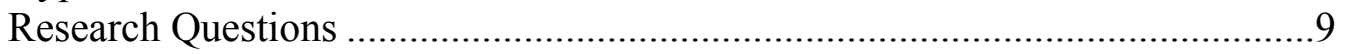

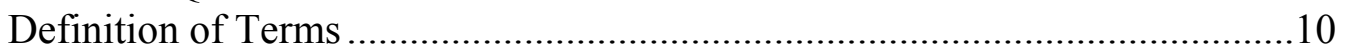

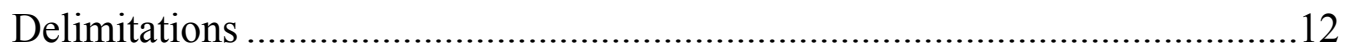

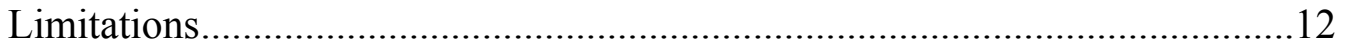

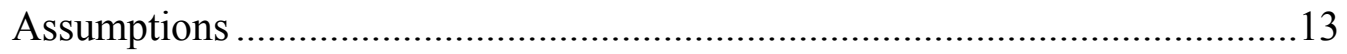

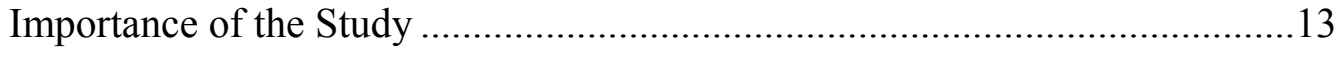

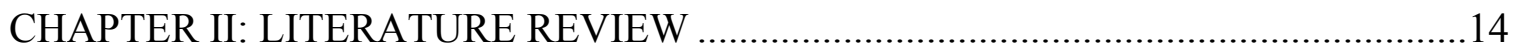

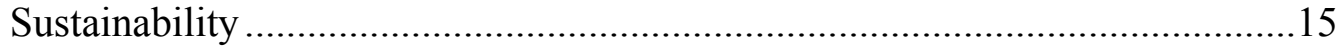

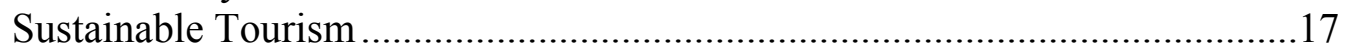

Environmental Tourism Impact....................................................................20

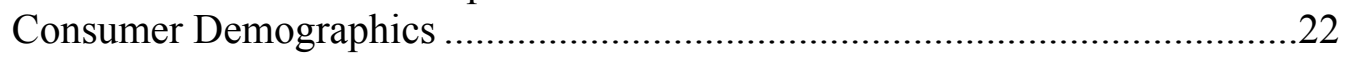

Consumer Perceptions of Sustainable Hotels..................................................25

Cruise Line Environmental Impact ...........................................................26

Cruise Line Economic Impact ........................................................................31

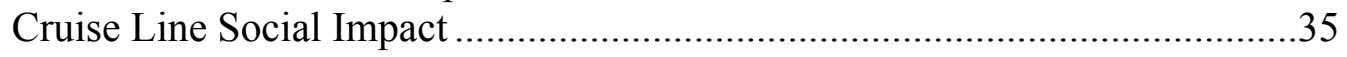

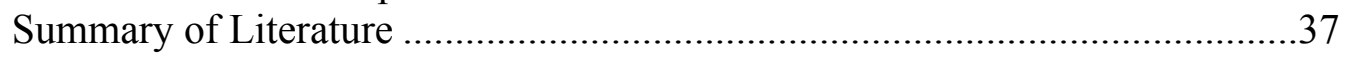

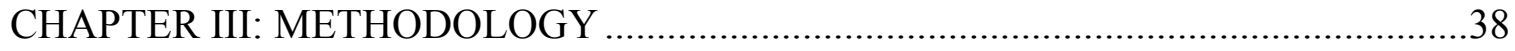

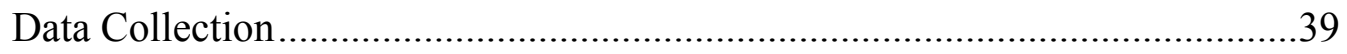

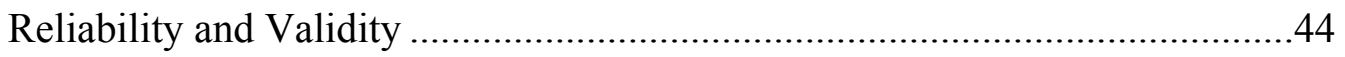

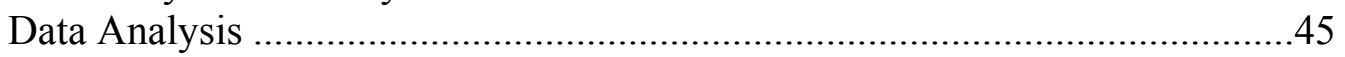

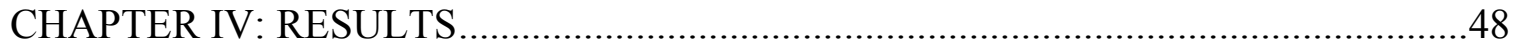

Data Collection and Participant Population ...................................................49

Demographics and Cruise Background .........................................................50

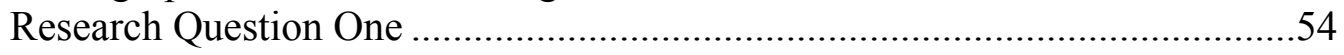

Research Question Two.............................................................................58

Research Question Three...........................................................................62

Research Question Four ..............................................................................65

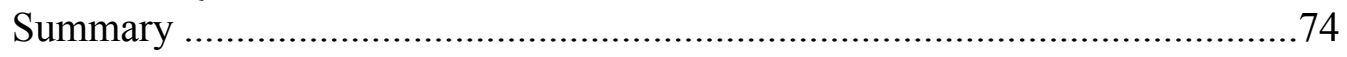




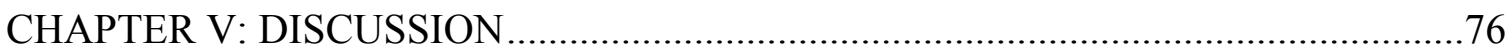

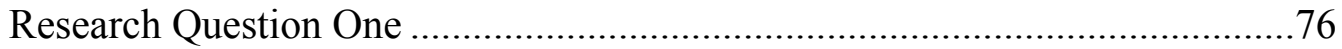

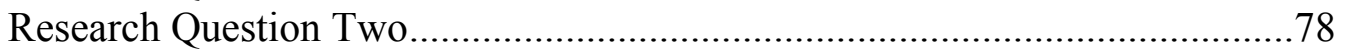

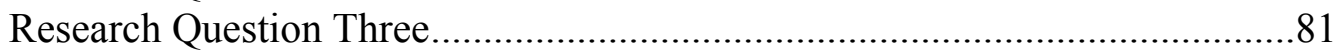

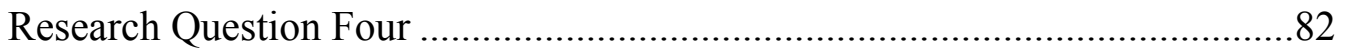

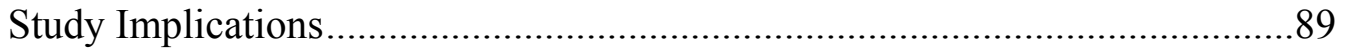

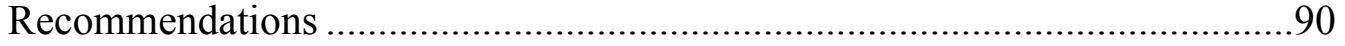

Suggestions for Further Research........................................................91

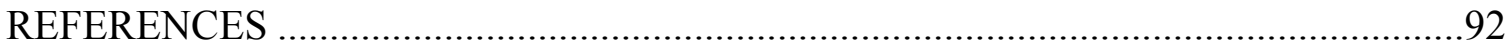

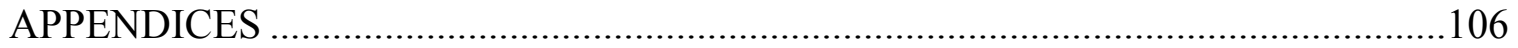




\section{LIST OF TABLES}

TABLE

PAGE

Table 1. Preferred cruise line for respondents who have previously sailed .....................54

Table 2. Importance of factors for survey respondents when booking a cruise .................55

Table 3. Percent of respondents scores for cruise industry sustainability .......................64

Table 4. Respondent scores for cruise lines sustainability ........................................65

Table 5. Respondent differences in gender for general sustainable factors when choosing a cruise

Table 6. Respondent differences in gender for environmental sustainable factors when choosing a cruise

Table 7. Respondent differences in gender for economic sustainable factors when choosing a cruise

Table 8. Respondent differences in gender for social sustainable factors when choosing a cruise. 


\section{CHAPTER I: INTRODUCTION}

The cruise industry is a multibillion-dollar industry that has evolved since its creation (Mak, Sheehey, \& Toriki, 2010). The origins of the cruise industry began in the 1800s with Arthur Anderson and Samuel Cunard. It is believed that Anderson established the idea of cruising in the Shetland Journal with a fake cruise advertisement (P\&O, n.d.). Anderson then went on to found Peninsular Steam Navigation Company in 1837 with Brodie McGhie Wilcox (P\&O, n.d.). By 1840, Peninsular Steam Navigation Company became Peninsular and Oriental Steam Navigation Company, more commonly known as P\&O (P\&O Cruises, n.d.). P\&O then expanded with shipping into the East and obtained additional contracts from the Royal Mail, which further grew the shipping company (P\&O, n.d.). The company later implemented Anderson's idea of cruising for leisure in the Mediterranean with the sale of round trip tickets (P\&O, n.d.). P\&O's leisure cruises had a large influence on the beginning of the cruise industry. The first cruise has often been touted to have taken place in 1840 on the RMS Britannia. In 1840, Cunard took 63 passengers on the RMS Britannia across the Atlantic (Gulliksen, 2008). The RMS Britannia was the first ship to have established voyages for passengers (Branchik, 2011; Butler, 2004). Anderson and Cunard had a large influence on the beginning of the leisure cruise industry and transportation of passengers.

Since the beginning of the passenger cruise industry, cruising has changed to the leisure market and no longer focuses solely on the transportation of passengers. Cruise travel can be defined as a "passenger ship used for pleasure voyages. The voyage itself and the ship's amenities [consisting] of transportation, accommodation, dining, ship- 
board entertainment, recreational activities, domestic and foreign ports of calls, and shore excursions, are considered the essential part of the experience" (Sun, Jiao, \& Tian, 2011, p. 747). The cruise industry caters towards a wide range of consumers with resort style cruising, expeditions, sailing yachts, tall sailing ships, and river cruising (Dowling, 2006; Showker, 2010). Cruise travel is a worldwide industry that covers every continent and allows passengers to sail anywhere that can be reached by sea or river (Showker, 2010). Passenger ships vary in size from small yachts to large vessels that can carry up to 5,000 passengers (Gulliksen, 2008). Passengers can rock climb, watch Broadway style shows, ice skate, zip line, etc. (Royal Caribbean International, n.d.). Cruise ships have varying amenities from each line, but many vessels are considered floating resorts that offer passengers a resort experience at sea. This has created competition between cruise lines to create larger and unique passenger vessels.

The cruise industry is the fastest growing sector in the travel industry and has experienced an increase in the growth of passengers since the 1970s (Clancy, 2008). As stated by Cruise Lines International Association (CLIA), approximately 500,000 passengers sailed on a cruise in 1970 and by 2009 the number has increased by over 2,100 percent ("Profile of the U.S. Cruise," n.d.). In 2014, the forecast for estimated number of passengers sailing on a cruise was 21.7 million worldwide (Cruise Lines International Association, 2014). Furthermore, there will be 24 new ships introduced by CLIA cruise line members in 2014 and 2015, which will add an additional passenger capacity of 37,546 to the market (Cruise Lines International Association, 2014). With the addition of new ships and more passengers, the cruise industry is expanding into new destinations. Major cruise lines add new itineraries in order to expand into regions that 
are less explored, and to market to new cruisers and repeat passengers (Cruise Lines International Association, 2013). The increase of passengers and cruise ship sizes has propelled major port cities to reconstruct ports in order to accommodate cruise ships and more cargo vessels. The act of dredging has happened in ports globally to accommodate larger vessels. Dredging removes debris and sediments in channels and harbors, which can increase the depth of channels and harbors for ships to navigate and dock at (National Ocean Service, n.d.). Increased channel and harbor depths are believed to help boost economic benefits in ports and surrounding areas by accommodating larger vessels. In Port Canaveral, government officials believe expanding the port, building new cruise terminals, and deepening waterways will help to generate up to 6,000 jobs and bring in more revenue for the region (Florida Seaport Transportation, 2014; Gibson, 2013; King, 2014). The cruise industry has a larger impact throughout the global community both economically and environmentally. As the industry continues to expand, this raises questions and concerns about sustainability and the effect of cruise ships on the environment due to the increasing size of the cruise industry.

Cruise line sustainability has been a concern for environmental groups and governmental agencies due to pollution, sewage, and harm to the oceans. Environmental advocacy groups and news agencies have reported on the failure of cruise lines to uphold safe environmental practices. A large issue that is examined by advocacy groups and governmental agencies is the dumping of garbage, graywater, black water, and bilge water. An article by the Associated Press noted the government in the Cayman Islands had been able to trace garbage on the local shore from passing cruise ships (Melia, 2009). The dumping of water is a concern due to the factors that may be present in graywater, 
black water, and bilage water. Graywater, also referred to as sullage, is different from black and bilge water because it can be recycled. The United States Environmental Protection Agency views graywater as "reusable wastewater from residential, commercial and industrial bathroom sinks, bath tub shower drains, and clothes washing equipment" (Environmental Protection Agency, n.d., c). Graywater is recyclable but needs to be treated in order to reuse the water (Environmental Protection Agency, n.d., c). Black water, also referred to as wastewater, is different from graywater because it is considered hazardous sewage waste. Black water is viewed as wastewater by the EPA, which comes from toilets, bidets, and kitchens (Environmental Protection Agency, 2012). Bilge water is found on the lowest part of a vessel and comes from a variety of different sources onboard the vessel that have either leaked or spilled, which then collect in the bilge. The EPA defines bilge waters as a "mixture of water, oily fluids, lubricants, cleaning fluids, and other similar wastes" (Environmental Protection Agency, 2008, p. 1). The dumping of graywater, black water, and bilge water is a concern in the maritime industry due to possible chemicals and contaminates that may be present in the water. In 2011, news agencies reported the United States EPA fined Princess Cruises $\$ 20,000$ when the Golden Princess dumped pool water into Glacier Bay National Park in Alaska (Sloan, 2013). Dumping has long been a concern for environmentalist groups due to possible chemicals and toxins that may be present in the materials.

Cruise line failure to follow international laws on environmental practices has led environmental groups to closely watch the industry. Friends of the Earth, an environmental advocacy group, has published yearly report cards on the environmental footprint of major cruise lines. The report cards examine sewage treatment, air pollution 
reduction, water quality compliance, and changes from the previous year. In 2014, CLIA North America had 26 cruise line members (Cruise Lines International Association, n.d., a) and worldwide CLIA had nearly 60 cruise line members (Cruise Lines International Association, n.d., b). The report by Friends of the Earth only examined 16 major cruise lines with a total of 162 cruise ships. The cruise lines examined are based in the United States, the United Kingdom, Italy and Japan. For 2013, only Disney Cruise Line received an overall grade of A and seven cruise lines received a D or lower grade (Friends of the Earth, 2013). Disney Cruise Line was the only line to receive an overall grade of A out of the 16 lines examined. Seven cruise lines received a grade of D or lower, these lines were Regent Seven Seas Cruises, Silversea Cruises, Oceania Cruises, MSC Cruises, P\&O Cruises, Costa Cruises, and Crystal Cruises (Friends of the Earth, 2013). Between the seven cruise lines, most sail to exotic destinations. Silversea Cruises has three expedition ships that sail to destinations in Antarctica, the Galapagos, and Asia (Silversea, n.d.). Reports and environmental studies can provide consumers information on cruise lines. This can inform consumers of cruise industry behavior towards the environment and how the industry is progressing on sustainable practices. Sustainable studies on the cruise industry examine one or more of the three pillars of sustainability. The three pillars of sustainability examine the environment, economy, and social equality (General Assembly of the United Nations, n.d.). The environmental pillar of sustainability focuses on the protection of the environment from damaging effects of waste and pollution (Environmental Protection Agency, n.d., b). Areas of air and water quality are important to the environmental pillar and protecting fragile eco-systems throughout the globe (Environmental Protection Agency, n.d., b). The economic pillar of sustainability 
examines the idea of economic stability for communities from jobs, small businesses, supply and demand, and natural resource accounting (Environmental Protection Agency, n.d., b). Economic sustainability focuses the importance of using local resources to their best advantage for the local community, while using these resources responsibly to protect the environment. The social pillar of sustainability emphasizes social equality of human health, environmental and social justice, education, and security of resources (Environmental Protection Agency, n.d., b). The three pillars of the environment, economy, and social equality create the idea of sustainability. All three pillars of sustainability are seen throughout the cruise industry and are also interlinked. As the cruise industry expands, the three pillars of sustainability have become more visible.

Sustainability of the cruise industry is a concern that has emerged in the travel industry due to expansion of cruise lines and increased number of passengers. Consumers may view the idea of sustainability differently throughout the world due to demographic differences. Characteristics of demographics include age, gender, income, education level, status of employment, family size, marital status, and other categories that can be used to describe the structure of a population (Laroche, Bergeron, \& Barbaro-Forleo, 2001). Various demographic backgrounds can influence how a consumer may view tourism and the environment. There is a correlation between specific demographic characteristics that are more likely to favor environmentalism (Laroche et al., 2001).

Gender, age, education, and income are considered important factors for examining an individuals attitudes and behavior towards the environment since these factors can influence a consumers purchasing behaviors (Im, Bayus, \& Mason, 2003; Laroche et al., 2001; Torgler, Garcia-Valiñas, \& Macintyre, 2008). McIntyre, Meloche, 
and Lewis (1993) noted women are more likely to favor environmentally friendly products compared to men. Furthermore, women are more likely to be concerned about the well being of others and are more socially conscious (Eagly, 1987). Some studies have found age to have an influence on environmental perceptions. Age differences have been shown to influence consumers' decisions and buying patterns (Im et al., 2003). Earlier studies on environmentally friendly consumers found age influenced social conscious intentions (Anderson \& Cunningham, 1972; Berkowitz \& Lutterman, 1968). The findings found younger customers are more likely to purchase environmentally friendly products (Evanschitzky \& Wunderlich, 2006). The impact of demographics plays an important role in the viewpoint of consumers. With concerns that emerge about sustainability, this leads to the question of how do consumers view the cruise industry and sustainability.

\section{Statement of the Problem}

Travel industry research has encompassed consumer perceptions regarding sustainability and environmental awareness, but primarily focus on the hotel industry. Most of the research has examined green hotels and how consumers perceive sustainability and eco-friendliness in hotels throughout the globe (Han, Hsu, \& Lee, 2009; Han, Hsu, Lee, \& Sheu, 2011; Millar \& Baloglu, 2011). Consumer research of green hotels also focused on understanding consumer decisions and behavior (Kim \& Han, 2010; Han, Hsu, \& Sheu, 2010; Kim, Palakurthi, \& Hancer, 2012). In the research presented on consumer perceptions, demographics have influenced the consumer choices and opinions on sustainability (Anderson \& Cunningham, 1972; Berkowitz \& Lutterman, 
1968; Im et al., 2003; Laroche et al., 2001; McIntyre et al., 1993; Torgler et al., 2008).

Research on consumer perceptions of sustainability in the tourism industry does not focus on ocean travel.

The research on sustainability in the cruise industry does not examine the perspective of the consumer. The research is from the perspective of environmentalists and activists. Most research on sustainability in the cruise industry has focused mainly on the environmental pillar of sustainability (Environmental Protection Agency, 2008; Johnson, 2002; Luck, Maher, \& Stewart, 2010). Research on the three pillars of sustainability does not examine how consumers perceive the industry. There has been a lack of research on consumer perceptions and the three pillars of sustainability. Therefore, this research provides information to the cruise and travel industry about consumer perceptions of cruise line sustainability. This research examined consumer perceptions and determined trends among demographics in cruise consumers. The research helped to determine how consumers would like to see the cruise industry become more sustainable.

\section{Statement of Purpose}

The purpose of the study examined consumer perceptions of the three pillars of sustainability in the cruise industry. The quantitative study surveyed consumers on cruise message boards and social media to analyze their views of sustainability and studied consumer trends on the cruise industry and sustainability. 


\section{Hypotheses}

- H1: The cost of a cruise is more important than environmental friendliness when choosing a cruise.

- H2: Environmental friendliness is not as important to consumers as the itinerary of a cruise.

- H3: Sustainable practices are more important to younger cruisers when choosing a cruise than older cruisers.

- H4: Sustainable practices are more important to women when choosing a cruise than men.

\section{Research Questions}

1. What factors influence a consumer to book a cruise?

2. What sustainable factors are important to consumers when choosing a future cruise?

3. How do consumers perceive environmental, social, and economic impacts of sustainability in the cruise industry?

4. Are there differences within demographics on consumer perceptions of cruise line sustainability? 


\section{Definition of Terms}

Consumer Perception. The term perception refers to the idea of how an individual accumulates and assigns significance to information through his or her five senses (Stanton, Etzel, \& Walker, 1994). Consumer perception expands on the idea of accumulating information. Consumer perception is defined as "the entire process by which an individual becomes aware of the environment and interprets it so that it will fit into his or her frame of reference" (Walters \& Bergill, 1989, p. 333). In this study the idea of consumer perception referred to how cruise consumers thought and interpreted sustainability in the cruise industry.

Sustainability. The United States Environmental Protection Agency has defined sustainability as, "everything that we need for our survival and well-being depends, either directly or indirectly, on our natural environment. Sustainability creates and maintains the conditions under which humans and nature can exist in productive harmony, that permit fulfilling the social, economic and other requirements of present and future generations" (Environmental Protection Agency, n.d., a). The concept of sustainability presented by the EPA connects into the ideas presented by E.F. Schumacher in Small is Beautiful: A Study of Economics as if People Mattered. Schumacher's ideas of sustainability with environmental awareness and social responsibility are the basis of sustainability. Schumacher examined the economy as unsustainable because natural resources have been treated as disposable and nature is not resistant to the pollution we release into the environment (Schumacher, 1973). Schumacher saw the need to "encourage other men and women to change society by 
offering them an example by being economically healthy and socially responsible" (Schumacher, 1973, p. 208).

Human needs are important in the idea of sustainability presented by Schumacher, with a need for helping those in the non-modern sector and in developing countries. Schumacher's work helped to inspire sustainability. The most commonly accepted definition of sustainability came from the Brundtland Report published by the United Nations. The two key concepts on sustainability from the Brundtland Report State: "the concept of 'needs', in particular the essential needs of the world's poor, to which overriding priority should be given; the idea of limitations imposed by the state of technology and social organization on the environment's ability to meet present and future needs" (World Commission on Environment and Development, 1987, p. 37). The Brundtland Report is an important document presented by the United Nations on sustainability. Furthermore, sustainability is broken into three pillars focusing on the environment, economy, and social equality. The pillar of environment focuses on the protection of ecosystems and the conservation of resources. In this pillar, there is a concern for the depletion of resources and global warming (World Commission on Environment and Development, 1987). The pillar of economy focuses on the stability of jobs for communities, supply and demand, and natural resource accounting. Natural resource accounting measures the resource available and the ability to conserve this resource for the environment and the future economy (Environmental Protection Agency, n.d., b) The social pillar of sustainability emphasizes the creation of social justice and public awareness. The pillar works to create security of resources, health care for the public, education, and family planning tools to help communities (World Commission on 
Environment and Development, 1987). The definition of sustainability for this research study included the ideas presented by the EPA; the ideas of environmental awareness and social responsibility presented by Schumacher; the commonly accepted definition of sustainability from the Brundtland Report; and the three pillars of sustainability.

\section{Delimitations}

This study was delimited by time and location for data collection. Data was collected during a one-month period, which started on June 1, 2014, and ended on June 30, 2014. The data collected for this study focused on consumers on cruise message boards and social media. The survey was only conducted in English. Facebook and two cruise message board websites were used for the collection of data. The two cruise message boards were Cruise Critic and Cruisemates.

\section{Limitations}

The study was limited by data collection location and sampling. This study was limited to surveys in an online environment. The data collection was restricted to cruise message boards and social media because the researcher could not access nearby cruise ports to survey consumers in person. Even though cruise message boards and social media reach a wide range of individuals, the responses for some age groups were limited. Cruisers 70-years and older may not partake in cruise message boards and social media due to lack of computer access and computer skills. Data collection was restricted to participants who choose to partake in the survey from cruise message boards and social media. 


\section{Assumptions}

The researcher made the following assumptions: (1) The instrument created to question cruise consumers had been designed appropriately to determinate consumer perceptions on cruise line sustainability. (2) All participants in the online survey answered the questions honestly and without any prejudice.

\section{Importance of the Study}

This study is important in understanding of consumer perceptions on sustainability in the cruise industry. Research in the cruise industry has mainly focused on the environmental impact of cruise ships, flags of convenience, and the impact of cruise ships on ports. Studies on consumer perceptions on sustainability in the travel industry have focused primarily on hotels. The role of this study was to bring attention to consumer perceptions and what sustainable practices may play a role in their booking a cruise. This is important because it will help in understanding where cruise lines can change future sustainable practices in order to follow consumer preferences. With this research, cruise lines will be able to gain knowledge on how consumers perceive sustainability in the cruise industry. 


\section{CHAPTER II: LITERATURE REVIEW}

The purpose and goal of this study was to gain insight into consumer perceptions of sustainability in the cruise industry. There was a lack of research on this topic in the tourism field and previous research alternatively focused on the consumer perception of sustainable tourism and hotels. Those studies were important to examine because they help the tourism community understand how consumers perceive sustainability and environmentalism in the hospitality industry. As the tourism industry expands, some tourism markets see degradation of resources and loss of respect for the local communities. While the tourism industry continues expansion, it is essential to understand how to protect tourism destinations throughout the globe.

The examination of the tourism industry outside the cruise industry helps to understand some of the issues sustainability experiences, but this does not give an entire picture of what the cruise industry encounters. The cruise industry creates a lasting impact on ports of call and ecosystems. Since cruise lines have ships stationed throughout the world and around every continent, the cruise industry creates substantial effects on the globally environment and economy. The examination of the cruise industry will help to bring focus to sustainable issues. Additionally, it was important to examine how consumers feel about the industry and if they understand the issues cruise lines may create globally. This may help in the education of consumers and cruise lines, and possibly bring change to the industry in the future. The first step to achieve future education was to examine the current research available on sustainability and environmental topics in the tourism industry. 


\section{Sustainability}

Sustainability has become more important to consumers and there has been an increase of how individual actions may affect the environment. E.F. Schumacher helped to bring attention to the idea of conserving resources in Small is Beautiful: A Study of Economics as if People Mattered. Schumacher saw and became concerned with the depletion of resources in society. In addition, Schumacher recognized the need for social responsibility towards others who do not have the ability to provide for themselves in the non-modern sector (Schumacher, 1973). Schumacher received international fame for Small is Beautiful, which influenced future environmentalists with the idea of sustainability (Mebratu, 1998).

In 1987, the United Nations World Commission on Environment and Development released the Brundtland Report. The report's purpose was to focus on "development that meets the needs of the present without compromising the ability of future generations to meet their own needs" (World Commission on Environment and Development, 1987, p. 41). The report presented one of the most routinely accepted definitions of sustainability (Edwards, 2005). In addition the Brundtland Report provided an understanding for society of the causes and effects for sustainability (Edwards, 2005). The causes and effects are commonly separated into three distinct categories of social equity, ecology, and economy (Vos, 2007). The standards presented in the report have influenced the standards of sustainability and are referred to in the debates of sustainable development (Lafferty \& Langhelle, 1999). The Bruntdland report also influenced the creation of three pillars of sustainability, which are commonly known as the three categories of causes and effects. 
There are three pillars to sustainability, which focus on three factors related to sustainable development. The pillars promote environmentalism, economic demands, and social equality (General Assembly of the United Nations, n.d.). The sustainable pillar of environment emphasized the reduction of pollution and harmful effects from waste; significance was also placed on the protection of eco-systems, air quality, and water quality (Environmental Protection Agency, n.d., b). One area of focus in the environmental pillar was water quality. Drinking water studies have examined the safety of water and the chemicals that may be found in the water (Khan et al., 2013; Li et al., 2014). A study conducted in China examined the frequency of flame-retardants in water to determine water quality drinkability (Li et al., 2014). A study in Pakistan examined the safety of water as a human right and the contamination found in local water throughout Pakistan (Khan et al., 2013). Studies in sustainability can cross pillars from environment to social equality, which was found in the case study in Pakistan (Khan et al., 2013).

The economic pillar of sustainability placed importance on jobs, incentives, supply and demand, natural resource accounting, costs, and prices (Environmental Protection Agency, n.d., b). The sustainable social pillar identified topics of environmental justice, human health, participation, education, resource security, and sustainable communities (Environmental Protection Agency, n.d., b). Human health is an area of social sustainability that can examine a wide range of health issues that stem from a variety of reasons. One study in Africa focused urban development that was unsustainable and created a negative impact on human health (Smit \& Parnell, 2012). The study by Smit and Parnell (2012) observed an increase in the link between human health and environmental sustainability. Increased population growth over a short time was 
noted to lead to poverty and strains on economic resources (Smit \& Parnell, 2012). The authors observed there was a connection between social and economic development. The three pillars of sustainability oftentimes are interlinked.

\section{Sustainable Tourism}

Tourism is one of the world's leading businesses and has a major role in commerce throughout the globe. The United Nations World Tourism Organization stated the volume of tourism "equals or even surpasses that of oil exports, food products or automobiles" (World Tourism Organization, n.d., d). Growth in the travel industry had increased dramatically from 1950 to 2000 . The World Tourism Organization states in 1950 there were 25 million travelers and in 2005 there were an estimated 806 million travelers (World Tourism Organization, n.d., b). In 2013, there were a record number of 1,087 million international tourists, which was an increase of five percent from the previous year (World Tourism Organization, 2014). Asia and the Pacific have seen a 13 percent increase of tourists yearly (World Tourism Organization, n.d., b). Tourism can create a large impact on the environment, which have led to the development of sustainable tourism.

Sustainable tourism has been recognized as a way to increase local development and to protect the environment and local heritage in tourism destinations (European Commission, 2006). The World Tourism Organization defined sustainable tourism as,

"Tourism that takes full account of its current and future economic, social and environmental impacts, addressing the needs of the visitors, the industry, the environment, and host communities" (World Tourism Organization, n.d., a). Even with a 
simple definition by the World Tourism Organization, there has been ambiguity in the idea of sustainable tourism (Torres-Delgado \& López Palomeque, 2012). There has been no agreed upon definition of sustainable tourism (Commission for Environmental Cooperation, 2000; Eurostat, 2006).

Previously the tourism industry had no criteria or standards to measure or create sustainable tourism $(\mathrm{Ko}, 2005)$. With no standards, this created the need for criteria to promote conservation and equality in tourism (Castellani \& Sala, 2010). Today, there are various standards that have been created by multiple organizations to promote sustainable tourism. The Global Sustainable Tourism Council and Green Globe are two examples of organizations that promote set standards (Global Sustainable Tourism Council, n.d., b; Green Globe, n.d., a). In 2008, over 50 organizations developed a set criterion that became known as the Global Sustainable Tourism Criteria (Global Sustainable Tourism Council, n.d., b). The standards focused on "effective sustainability planning; maximizing social and economic benefits to the local community; reduction of negative impacts to cultural heritage; and reduction of negative [impacts to the environment]" (Global Sustainable Tourism Council, n.d., b). The standards presented by Green Globe relate to the three sustainable pillars by examining four specific areas in a hospitality business: social economy, cultural heritage, environment, and sustainable management (Green Globe, n.d., a). These standards are not required for businesses to follow but do set the minimum criteria for tourism businesses wanting to become sustainable (Global Sustainable Tourism Council, n.d., b).

Sustainable tourism focuses on the protection of tourist destinations for future generations by the prevention of the "exploitation of natural, cultural and all other tourist 
resources from the current generation" (Angelevska-Najdeska \& Rakicevik, 2012, p. 210). The idea of preventing exploitation in sustainable tourism is faced with challenges. With the creation of suggested standards, there has been a lack of regulations in some countries on the protection of communities' deterioration from mass-tourism (Butler, 1999). Day sets out three issues that sustainable tourism faces. The first challenge Day examined is the vagueness of sustainability in tourism. Day believes the definition by the World Tourism Organization is "conceptually appealing, this definition is not prescriptive and does not provide a clear 'road map' for practitioners wishing to adopt the concept" (Day, 2012, p. 1). Day noted the challenge of the definition is due to the wide range of communities who would have to determine what works for them. Every community is different and Day stated there is "no single way to do "sustainable tourism" (2012, p. 1). The second challenge Day presented is the implementation of sustainable tourism, to a tourism system, that is complex with many different participants. Tourism experiences provide a range of services to tourists and Day notes there is "top down" approach to how travel is operated. Organizations, such as the National Tourism Authorities, can advocate for sustainable tourism but are unable to police the industry (Day, 2012). The industry lacks governance and official regulations (Hall, 2011). The third challenge of sustainable tourism has been the embracement of sustainable practices. As in challenge two, tourism is a complex system that includes many destinations and participants. Every participant in the system would need to learn a new set of standards in order to become sustainable (Day, 2012). There will need to be a "readiness to change" for a business to become sustainable (La Lopa \& Day, 2011). One of the issues is that 
researchers have the knowledge of sustainability, but tourism businesses may not know how to plan and move forward with sustainable practices (Ruhanen, 2008).

As tourism business sees continued growth, the environment will continue to change due to strain. Being the leading business of the world, the travel industry can create a large impact. Every year new destinations become popular and other destinations mature with an increased number of visitors. In 2020, the World Tourism Organization estimates the number of travelers as " 1.2 billion will be intraregional and 378 million will be long-haul travelers" (World Tourism Organization, n.d., c).

\section{Environmental Tourism Impact}

Negative environmental impacts from tourism are common. Studies conducted by the United Nations Environment Programme have found three main areas affected from tourism where the environment is unable to mange change: depletion of resources, sewage, and physical impacts (United Nations Environment Programme, n.d., b). Water resources are critical for the environment and tourism destinations because of the increased amounts of water used for activities such as golf, kitchens, guest rooms, pools, and gardens. Dry destinations that have a limited amount of water resources are greatly affected by consumption. A tourist will use more direct water on vacation versus being at home. On vacation a tourist uses on average 300 liters of water per day compared to 160 liters of water at home per day (Gössling et al., 2012). At hotels consumption of water is the highest due to daily upkeep of cleaning rooms, laundry, and filling pools (Eurostat, 2009). Water resources are not the only aspect of depletion of resources. The use of local 
resources such as food and raw materials are amplified in tourism destinations from demands such as heating, hot water, and local food products (Camarda \& Grassini, 2003).

One of the more popular tourist destinations in the Caribbean has demonstrated the consequences facing marine life from over exposure to tourism. In Grand Cayman, swimming with stingrays is a sought-after tourist activity. A sandbar known as Stingray City can see up to 40 tour vessels at one time with up to 2500 tourists (Shackley, 1998). The stingray experience for tourists includes holding, touching, and feeding the stingray. Everyday stingrays migrate to the site due to the feeding, which has been found to be a permanent habitat (Semeniuk, Speers-Roesch, \& Rothely, 2007). In 2009, a study conducted by Semeniuk, Bourgeon, Smith, and Rothley compared stingrays in tourist and non-tourist sites. The study found stingrays in tourist sites had "lowered hematocrit, lowered total serum proteins, differential leukocrit and leukocyte reactions, and exhibited oxidative stress" (Semeniuk et al., 2009, p. 1818). The outcome is believed to be from exposure to tourists, which caused a negative physiological effect during visitations to Stingray City. Stingrays exposed to tourists continually showed weakened selfmaintenance and protection systems due to "unnatural food, high injury rates and increased parasite loads" (Semeniuk et al., 2009, p. 1827). The comparison of stingrays in tourist environments and non-tourist environments had shown the impact of tourism on the environment.

Around the globe tourism has strained environments and caused physical changes in these environments. Coastal regions have experienced some of the most noticeable changes due to the demand for beaches, scenic views, and resorts. The disappearance in land due to building of resorts and car parking facilities has been highly noted. In Turkey, 
urbanization has increased from 18.5 percent to 62 percent from 1950 to 2000, with 51 percent of this total being developed in coastal regions (Burak, Doğan, \& Gazioğlu, 2004). The addition of structures can alter sand supply to coastal beaches. Fauna and flora in the Mediterranean have disappeared due to natural habitats being replaced with golf courses, marinas, and street lighting (Davenport \& Davenport, 2006). In Swansea, South Wales, United Kingdom, tourists and fisherman who search for crabs have destroyed much of the local fauna due to overturning rocks (Liddiard, Gladwin, Wege, \& Nelson-Smith, 1989). An estimated 3000 rocks were turned over in one site during low tide and 90 percent of the rocks were turned over multiple times within a two-week period (Bell et al., 1984). Fauna and flora were reduced due to rock movements and rocks not being replaced in the original spots. This reduced diversity and stability for the fauna and flora in the region. The disappearance and physical changes in land alters the environments and forever has changed ecosystems around the world.

\section{Consumer Demographics}

Evidence from research has found the impact of environmental concerns does have an impact on decision-making processes and purchasing behaviors for some consumers (Gilg, Barr, \& Ford, 2005; Hackett, 1993; Kilbourne \& Beckmann, 1998; Zimmer, Stafford, \& Stafford, 1994). Demographics can influence consumer perceptions and some specific demographic characteristics are more likely to influence a consumer to favor environmentalism (Larcohe et al., 2001). An individual's background and lifestyle choices can affect his or her choices when it comes to the environment. Environmental identity is connected to an individual's social and environmental views of the world, 
which is influenced by his or her cultural background (Kashima, Paladino, \& Margetts, 2014). Furthermore, individuals who are materialistic are less likely to be concerned about the environment (Brown \& Kasser, 2005; Good, 2007). Early studies on demographics on the environment found socially conscious individuals were more likely to be female, younger, have above average economic status, and have completed a higher level of education (Anderson \& Cunningham, 1972; Berkowitz \& Lutterman, 1968). Demographics have shown an influence on consumer behavior towards environmental consciousness (Laroche et al., 2001). Torgler et al. (2008) found age and gender to be important demographics when examining consumer environmental perceptions and behavior towards the environment.

Age of consumers can influence the environmental view of an individual. This can be influenced by an individual's generation he or she was born into (Vlosky \& Vlosky, 1999). The cohort effect is the difference in viewpoints and outlooks by various generations. This is established by the various life experiences a generation may face from the economy, political experiences, and social life (Vlosky \& Vlosky, 1999). The consumer decision-making process is influenced by the age of the consumer (Han et al., 2009). Information processing has seen younger individuals focused on new ways to search for information and alternative resources for information (Evanschitzky \& Wunderlich, 2006). Older individuals are more likely to go to information that already exists from sources he or she relies on (Evanschitzky \& Wunderlich, 2006). This thought process in information processing also influences a consumer's reaction to trying something new. Younger consumers are more likely to try new products or services, while older consumers are more likely to be conservative about new products when 
making a purchase decision (Im et al., 2003). Environmentally friendly individuals have been noted to come from many age groups (Roberts, 1996). Younger individuals demonstrate a higher level of knowledge on the environment (Arcury, Scollay, \& Johnson, 1987; Grunert \& Kristensen, 1992). Howell and Laska (1992) noted younger consumers are more likely to be concerned with the environment than older consumers.

Gender is one demographic that has been noted to show differences in environmentalism. Consumption patterns and decision-making processes for male and female consumers have been noted to differ (Han \& Ryu, 2006). Females have shown a difference in a social role compared to males. Females are also more likely to be concerned about the welfare of other individuals (Eagly, 1987). Bekkers' (2005) research noted females are more likely to volunteer than males. In a study conducted by Lehto, O'Leary, and Lee (2001), female consumers showed a higher preference towards communication and the attainment of information over male consumers. For environmental attitudes, females have been shown to be more ecologically aware than men (Banerjee \& McKeage, 1994; McIntyre et al., 1993). Female consumers have been found to show more concern for the environment at any age compared to male consumers (Zelezny, Chua, \& Aldrich, 2000). Laroche et al. (2001) noted women who were married with children were more likely to be concerned about the environment. In a study conducted by Diamantopoulos, Schlegelmilch, Sinkovics, and Bohlen (2003), it was stated females are more likely to recycle and exhibit "greener shopping habits" (p. 475). 


\section{Consumer Perceptions of Sustainable Hotels}

Hotels and tourism businesses are under pressure to become more environmentally friendly and sustainable (Foster, Sampson, \& Dunn, 2000). Concern from the public on environmental degradation has led hotel operators to focus on making their operations environmentally friendly (Han et al., 2009). American travelers have expressed their concerns over the impact of travel on the environment (Vora, 2007). Fifty-four percent of American travelers prefer to stay in hotels that are environmentally friendly (Kirk, 1995). The hotel industry has experienced an increase of customer preference for hotels that show concern for the environment (Han et al., 2010; Manaktola \& Jauhari, 2007). Manaktola and Jauhari conducted a study in India on consumer perspectives on green hotels. Twenty-two percent of survey respondents search for information on eco-friendly practices in hotels in India (Manaktola \& Jauhari, 2007).

Manaktola and Jauhari (2007) noticed there was a relationship between consumer outlook and behavior towards eco-friendly practices. Consumers who are concerned about the environment are more likely to stay at an environmentally friendly hotel (Kim \& Han, 2010). Han et al. (2010) noted 30.3 percent of the respondents were not sure if they had stayed at hotels that would be classified as green. The purpose for needing a hotel did not influence a consumer's choice for choosing to stay at an eco-friendly hotel (Kim et al., 2012). Millar and Baloglu (2011) noted not all consumers viewed green hotels favorably and the most noted unfavorable response from consumers was regarding expense.

The background of consumers influenced their choices. Consumers can perceive environmental practices differently and this can depend on factors such as culture, 
personal backgrounds, and motivations (Tyrväinen, Uusitalo, Silvennoinen, \& Hasu, 2014). The difference between females and males is noted in terms of environmental choices. Females are more likely to choose a green hotel and rate a green hotel favorably over males (Han et al., 2011; Kim et al., 2012). In the study by Han et al. (2011), age was found to not play a significant role for consumers in choosing green hotels. Age compared differently in the study by Millar and Baloglu (2011) where younger survey participants were more favorable of green hotels than participants 60 years and older. Income can have an impact for consumer choices and varies from study to study Kim et al. (2012) found consumers who made more than $\$ 50,000$ were more likely to choose green hotels. Han et al. (2011) noted there was no notable difference in income for choosing a green hotel.

\section{Cruise Line Environmental Impact}

The cruise industry has shown a wide-reaching impact on the environmental pillar of sustainability. Cruise lines have ships stationed in every ocean throughout the globe and some of these vessels are located in delicate ecosystems. Every five years new cruise ships released see an increased length of 90 -feet compared to previously released ships (Bell, 2007). The continued growth and expansion of the cruise industry has created concerns among environmental organizations and government agencies about the impact the industry has on marine life and the environment (Environmental Protection Agency, 2008). The United States Environmental Protection Agency received a petition in March 2000 from the Bluewater Network to request investigations and regulations to address pollution from cruise ships. The petition focused on cruise waste volumes and 
characteristics, analysis of cruise ship water quality, the impact on human health, and air pollution (Environmental Protection Agency, 2008). The response to this petition from the EPA was the Cruise Ship Discharge Assessment Report. The EPA surveyed 29 ships sailing in Alaska and found sewage generation rates ranged from 1,000 gallons to 74,000 gallons a day (United States Congress, 2013). If human sewage is discharged from a passenger vessel, this can contribute to dangerous algal blooms in the ocean that can have a negative impact on the environment (United States Congress, 2013).

The dumping of waste and sewage has been a concern in the cruise industry. The concern with waste from cruise ships is due to the volume and potential hazard they create, which is similar to the waste generated from hotels (Environmental Protection Agency, 2008). Cruise lines have attempted to cover up past incidents of dumping. In 2005, Celebrity Cruises' Mercury was fined for dumping untreated wastewater in Puget Sound. Five hundred thousand gallons of wastewater were dumped, but Celebrity Cruises claimed the ship did not dump into Puget Sound. Shipboard documents later contradicted the claim, which lead to a $\$ 100,000$ fine (Luck et al., 2010, p. 123). With cruise ship dumping, there is the concern of illegal discharge that can effect the environment. This includes "sewage, graywater, hazardous wastes, oily bilge water, ballast water, and solid waste" (Brida \& Aguirre, 2008, p. 2). In 1999, Royal Caribbean International was fined $\$ 18$ million for discharging bilge water in Alaska (Brida \& Aguirre, 2008). In response to the environmental impacts from the cruise industry, the State of Alaska created cruise regulations to protect the environment. In July 2001, the Commercial Passenger Vessel Environment Compliance Program was established in Alaska ("Laws and regulations," 2014). The program was established in Alaska Statues, AS 46.03 .460 through AS 
46.03.490. The Alaska Department of Environmental Conservation and the Negotiated Regulations Committee developed regulations, which then were addressed by the public before going into effect in 2002 ("Laws and regulations," 2014). The Commercial Passenger Vessel Environment Compliance Program has addressed environmental problems cruise ships create from waste, sewage, graywater, and discharge ("Commercial Passenger Vessel," 2013). Alaska also has in place an Ocean Rangers program that has focused on the environment. The Ocean Ranger is part of the United States Coast Guard and monitors cruise ships compliance with both federal and state laws that regard "marine discharge and pollution and sanitation while the vessels are in Alaska" ("Ocean ranger program," 2013). The rangers observe cruise ships and monitor treatment systems onboard (Klein, 2012).

The EPA also established vessel discharge laws in Alaska that focus on the Alexander Archipelago, Kachemak Bay National Estuarine Research Reserve, and navigable waters in Alaska. The laws are part of Title XIV Certain Alaskan Cruise Ship Operations. Title XIV requires cruise ships to follow all the protections placed by the title, Federal Water Pollution Control Act, and applicable environmental laws (Environmental Protection Agency, 2012). The title has focused on illegal discharge of graywater and sewage in Alaska and sets the penalties for violators of the act (Environmental Protection Agency, 2012). With regulations in place, cruise lines still discharge illegally in Alaska. Sixty percent of the cruise ships "permitted to discharge in Alaska State waters were cited for violating Alaska Water Quality Standards in 2008, logging 45 violations" (Klein, 2011, p. 109). In 2009, the number of violations increased to 66 and 72 percent cited (Klein, 2011). 
The impact on the environment is a major concern in vulnerable regions of the world. In particular are Polar Regions, like Antarctica, which are a concern for environmentalists due to the possible impact of visitors and cruise ships. The concerns range from disturbance of birds and marine life, introduction of foreign-organisms, pollution, and introduction of radioisotopes (Luck et al., 2010, p. 109). Furthermore, from 2007 to 2009 Polar Regions in Alaska, Antarctica, Greenland, Norway, and Spitsbergen saw ten cruise ship groundings, one collision with an iceberg, and one sinking (Luck et al., 2010, p. 110). The concern with groundings and collisions could lead to possible oil spills. In January 2007, Hurtigruten's Nordkapp grounded in Antarctica and the ship sustained damage. The damage caused a diesel oil spill of 227 to 757 liters (Luck et al., 2010, p. 123). Other regions of the world have also faced an environmental impact from cruise ships. Venice, Italy, is one city that has tried to ban cruise ships from entering the Venice lagoon due to concerns of environmental deterioration (Squires, 2014). The environmentalist group, Amici di Venezia, have created petitions on cruise ship pollution and damage to the canal from the ship wakes (Standish, 2012). The wakes from the ships have created sediment resuspension in the lagoon (Gelinas, Bokuniewicz, Rapaglia, \& Lwiza, 2012; Rapaglia, Zaggia, Ricklefs, Gelinas, \& Bokuniewicz, 2011). There is also concern that the wake from the ships have eroded the walls of the shallow Venice Lagoon (Rapaglia et al., 2011).

As the cruise industry continues to grow and face environmental problems, dredging concerns have also emerged. The growths of the cruise industry have lead cruise ports to expand to accommodate the size of larger passenger vessels and Post-Panamax cargo ships. Port expansion and dredging of shipping lanes have become important to 
many ports to harbor Post-Panamax ships due to the expansion of the Panama Canal (Ramos, 2014). Seaports in the eastern United States have been competing to attract larger vessels by the expansion of their channel depths and ports to increase trade. Norfolk, Virginia was the only eastern seaport in the United States to accommodate PostPanamax ships, which have lead ports from Miami to New York to expand ports and channel depths to accommodate ships with fifty-foot drafts (Ramos, 2014). Dredging has impacted a large part of the environment. In Tampa Bay, Florida, 81 percent of the seagrass was lost due to dredging operations, which either removed or buried the seagrass (Lewis, 1976; Lewis, Durako, Moffler, \& Phillips, 1985). Dredging has further affected the environment by changing current speeds and wave conditions, which has affected seagrass and created erosion (Jensen \& Mogensen, 2000: MacInnis-Ng, 2003). Coral reef habitats have been destroyed during dredging due to burial, removal, or indirect consequences from stress caused by dredging from sedimentation or turbidity (Erftemeijer, Riegl, Hoeksema, \& Todd, 2012). Port dredging has been found to have an affect on wildlife. A study conducted in Aberdeen, Scotland in 2008, 2009, and 2012, found port dredging to impact bottlenose dolphin behavior (Pirotta et al., 2014). Aberdeen is one of the busiest ports in Northern Europe and it was noted vessel traffic did not affect dolphin behavior, most likely due to the readily available food. The study found dredging had a high impact on dolphin behavior. When there were high levels of dredging, dolphin activity and behavior changed, and "dolphins spent proportionally less time in the harbors as the intensity of dredging activity increased" (Pirotta et al., 2014, p. 399). The study found when dredging activity was present dolphin behavior was consistent throughout the study and dolphins spent less time in the harbor. The change in 
dolphin behavior is believed to be due to the added noise from dredging and the impact on sediment, which could effect communication and sight for the dolphins (Pirotta et al., 2014).

\section{Cruise Line Economic Impact}

The sustainability of cruise lines have shown a large effect on ports of call, the local population of ports, and the crew members on board a ship. The cruise lines have a large impact on the economic pillar of sustainability. Some cruise destinations benefit from the cruise industry and see a positive economic impact. In Central America and the Caribbean, cruise ships are supported by some businesses and the public (Espinal, 2005). Cruise passengers have contributed 21 million dollars to the economy (Brida \& Aguirre, 2008). One complaint for some ports of call is the lack of spending from tourists to help support the community (Johnson, 2002). Even though a large number of passengers will go to shore, everything a passenger wants such as food and transportation is all contained on a ship. When passengers visit a port, they are not likely to spend their money on "food, accommodation and transport" (Orams, 1999) since the items are available to them back on the ship. Cruise ships may not always create an economic benefit for some ports. Jamaican officials are unhappy because cruise passengers spend less than tourists at hotels. Tourists spent on average $\$ 115.74$ per day while a cruise passenger only spent $\$ 71.27$ (Myers, 2012). Jamaica's goal is for cruise passengers to spend $\$ 120$ a day (Myers, 2012). In Norway a study observed cruise passengers on average spent NOK 493 a day while other tourists spent on average NOK 630 (Larsen, Wolff, Marnburg, \& Øgaard, 2013). Cruise passengers spent less money compared to other tourists throughout 
Norway, though cruise passengers did spend less time in each port per day compared to other tourists (Larsen et al., 2013). Some destinations have become concerned with the number of cruise ship passengers and have now introduced passenger head taxes.

Bermuda has one of the highest tax rates at $\$ 63$ per person (Johnson, 2002).

Leakage in the economy is a concern for cruise destinations. Many small islands need to import goods and food in order to keep up with tourism (Murray, 2005). Even with tourism spending being high, leakage has needed to be taken into account due to businesses importation of goods to keep up with tourism demand. Even destinations with a high number of tourists who purchase accommodations, tours, food, and other items, may not see economic growth due to import expenses (Webster \& Ivanov, 2014). Tourism demands have also created a labor demand, which creates a transfer of laborers from other industries to the tourism industry. If there is not enough labor, this can create an import labor demand. Labor imports have created higher leakages due to employees sending their wages back to their own home country (Vanhove, 2011). Once leakage is deducted from the overall gross spending of tourists, the spending number will decrease and there are less economic benefits (Murray, 2005). Studies on leakage suggest leakage figures range from 40 percent to 80 percent in developing countries (Diaz-Benevides, 2001; Frueh, 1988; Meyer, 2006; Pattullo, 1996). Leakage is especially high in developing island nations where tourism is the main industry (Meyer, 2006). One example of leakage involves cruise passengers purchasing liquor in port. The liquor is primarily imported into a cruise port where passengers will purchase bottles, which will then lead to an increase in leakage due to the import costs (Dwyer \& Forsyth, 1998). When items outside of a region are the preferred purchases for tourists, this will lead to a 
reduction in locally made items (Dwyer \& Forsyth, 1998). Webster and Ivanov (2014, p. 139) believe the best way to avoid leakage in a countries economy is to "be competitive and attract tourists, but also to capture high shares of visitors' expenditures by offering locally produced products." When there is a demand for local products, this will increase products made locally and can provide more hours for locals to work and more jobs to those who previously were unemployed (Dwyer \& Forsyth, 1998). Leakage is a problem for destinations worldwide due to the travel industry from cruise ships to all-inclusive resorts (United Nations Environment, n.d., a).

The cruise industry has been able to gain power with lobbying groups in ports. It is believed cruise lines have used their lobbying influence in order to change and prevent certain laws being passed that may affect the industry negatively. In 2012, the Cruise Vessel Security and Safety Act had been changed before it was passed in Congress (Anglen, 2012). The change in the bill favored the cruise industry by requiring them to report all serious crimes on ships to the FBI. The original bill required cruise lines to report to the United States Coast Guard who maintains a database of serious crimes (Anglen, 2012). Reporting to the FBI would prevent any current investigations to be published in a public database. A spokesperson for CLIA announced after the bills change, the industry supported the change in the bill (Anglen, 2012). Cruise lines have influenced state taxes imposed on passengers. In 2006, a cruise ballot initiative in Alaska added a new head tax on cruise passengers. The tax added a 46-dollar head tax and a four-dollar ocean ranger tax (Resource Development Council, n.d.). This would require each passenger on a ship that docked in Alaska to pay an extra 50 dollars in taxes. A cruise-lobbying group in Alaska, the Alaska Cruise Association, filed a lawsuit in federal 
courts against the head tax (Jainchill, 2009). Pressure from the cruise industry and lobbyists lead to the reduction of the head tax (Resource Development Council, n.d.). Another example of lobbying is Carnival Corporation, who owns Carnival Cruise Lines, Holland America, Princess Cruises, and other major cruise lines. Carnival Corporation partnered with a Mexican firm, Puerta Cancun-Xcaret, SA de CV. The firm bid for a construction contract for building cruise terminals, which the Mexican government gave the contracts to (Brida \& Aguirre, 2008). Professor Ross Klein from Memorial University of Newfoundland has tracked information on the cruise industry and cruise lobbying groups. Klein (2013) reported the cruise industry spent a total of $\$ 48,440,955$ on lobbying the United States Congress. This also includes CLIA and the Arison Family Trust. The Arison Family Trust was created by the Arison family, who founded Carnival Corporation. Mickey Arison has been the Chairman of Carnival Corporation since 1990 (Carnival Corporation, n.d.).

Flags of convenience have become an issue in the cruise industry. A flag country is responsible for a ship and to certify the ship is complying will all international regulations, including those on pollution (Johnson, 2002). A ship that is flagged under convenience will have a different country of registration than the owner's nationality (Miller, 2002). In both the cruise and cargo industry flags of convenience are common. One example of a flag of convenience outside the cruise industry is in the Marshall Islands. The Deepwater Horizon oil rig was registered in the Marshall Islands even though the owner was Swiss and the operator of the rig was British Petroleum (Sharife, 2010). The Marshall Islands also does not have any oil reserves, however there are "221 registered oil tankers, four times as many as the United States" (Sharife, 2010, p. 111). 
The maximization of profitability has been one of the most important factors in the maritime industry for cargo, oil, and cruise companies (Bergantino \& Marlow, 1998). The three main countries for cruise ship registrations are the Bahamas, Panama, and Bermuda. In 2011, the Bahamas had 59 cruise ships registered, Panama had 30 cruise ships registered, and Bermuda had 23 cruise ships registered (Tre, 2011). Often ships under a flag of convenience will have underpaid staff and avoid strict labor laws (Toh \& Sock-Yong Phang, 1993).

\section{Cruise Line Social Impact}

Cruise lines have a large impact on the social pillar of sustainability. Flags of convenience have created shipboard environments where crews receive low wages, lack of power to strike, and poor working conditions (Wood, 2004). Flags of convenience have allowed ships to avoid disclosing ownership. In an investigation by The New York Times, some countries were found to not require the owner of a vessel to disclose who they are or require more than a signature to register (George, 2011; Sharife, 2010). The most important item for ship owners is operation costs. Many owners have looked to save costs instead of focusing on labor and safety conditions (Gregory, 2012; Wood, 2004). Flags of convenience have played a large role in the cruise industry and industry watchdogs believe cruise corporations want to avoid United States consumer protection and safety laws (McGee, 2013). The only major cruise line with a flag of registry in the United States is NCL America with the Pride of America (Lovitt, 2013). Additionally, some cruise lines have changed flags from the United Kingdom to avoid labor laws. In 2011, Cunard announced their vessels would change registration from the United 
Kingdom to Bermuda ("Cunard to register," 2011). The avoidance of labor laws has allowed cruise lines to pay particular nationalities less in wages.

Corporate social responsibility reports are important in social sustainability since this allows a company to acknowledge health, safety, and human rights. Due to the cultural background of the cruise industry, the industry has lacked the motivation to create an industry wide corporate social responsibility reports system (Bonilla-Priego, Font, \& Pacheco-Olivares, 2014; Campbell, 2007). The cruise industry has not reached a point where corporations imitate behavioral patterns (Bonilla-Priego et al., 2014; Ramus \& Montiel, 2005). A study conducted by Bonilla-Priego et al. (2014) addressed the acknowledgement from cruise corporations and created a corporate social responsibility index for the cruise industry. The study found company size had an impact on the release of corporate social responsibility disclosures. Brands within the Carnival Corporation and Royal Caribbean International reported corporate social responsibility, along with the small cruise operators of Disney Cruise Line and Thomson Cruise Line who are both connected to larger companies (Bonilla-Priego et al., 2014). The study noted it was surprising to find that Norwegian Cruise Line and MSC Cruises did not report on corporate social responsibility since both are larger cruise companies (Bonilla-Priego et al., 2014).

The social impact of cruises has affected employees and a destination. Norwegian Cruise Line sails throughout the Hawaiian Islands year round and created controversy by Hawaiian musicians. All Hawaiian musicians were let go by Norwegian Cruise Line and then replaced by Filipino musicians who received a lower salary (Klein, 2011). The Filipino musicians were made to look like Hawaiian musicians by being dressed in 
Hawaiian shirts and playing Hawaiian music (Klein, 2011). This upset local Hawaiian natives and created a situation that effected social authenticity (Klein, 2011). Cruise ships can create a negative impact on the local populations perception towards tourists. A destination can be crowded when there are multiple cruise ships docked, which can disrupt local activities and routines. Klein (2005) noted this has made local residents of various cruise ports, such as Nova Scotia, to become frustrated due to cruise tourism. Cruise tourism has created a social impact on the daily lives of residents and crew globally.

\section{Summary of Literature}

Primarily research on consumer perceptions on sustainability in tourism has focused on hotels. Previous research examined the insight of the consumer and analyzes consumer decisions. It is important to understand the impact of consumer perceptions in the hotel industry, in order to bring focus to consumer perceptions of the cruise industry. In the cruise industry, research related to sustainability primarily focused on environmental issues and flags of convenience. These studies are important to examine to understand the overall sustainable issues throughout the cruise industry. Overall, research studies are specific towards issues the industry has created and do not focus on the consumer perception. There has been a lack of research on consumer perceptions of sustainability in the cruise industry, and through this research study the researcher has attempted to close this gap. 


\section{CHAPTER III: METHODOLOGY}

In this study, research was conducted to better understand consumer perceptions of sustainability in the cruise industry. Previous studies about consumer perceptions on sustainability have focused on hotels and green hotels (Han et al., 2011; Han et al., 2009; Millar \& Baloglu, 2011). The researcher was unable to find any literature or previous studies on consumer perceptions of sustainability in the cruise industry. The lack of data available on perceptions created a need for a study on consumers in the cruise industry. A quantitative study was created to measure the various views of consumers on sustainability and to see if there were any trends in consumer opinions. A survey was conducted to measure consumer perceptions. The instrument was created from the information presented by CERES' Green Hotel Initiative Best Practice Survey, the Global Sustainable Tourism Council's [GSTC] criteria for hotels and tour operators, and the Green Globe certification standards.

The Green Hotel Initiative covers environmental standards and was created by the Coalition for Environmentally Responsible Economies. The best practice survey was created for hotel properties to briefly examine management practices for environmental commitments (CERES, n.d.). The environmental standards, which individuals think of as going green, can easily be confused with the idea of sustainability. Sometimes it is easy to think of sustainability as just 'going green,' but sustainability examines social justice, the economy, and the environment. Since the average consumer may not know the difference, the questionnaire included the ideas of 'going green.' The criteria presented by both GSTC and Green Globe were used since these are the sustainable guidelines 
presented for hospitality companies wanting to become sustainable. GSTC created a set of international standards for businesses that seek to be sustainable in the tourism field. The standards by GSTC have focused on sustainable topics businesses should strive to reach. The criteria were created in "response of the tourism community to the global challenges of the United Nations' Millennium Development Goals" (Global Sustainable Tourism Council, n.d., a). The standards by Green Globe were developed from those presented by GSTC, Baseline Criteria of the Sustainable Tourism Certification Network of the Americas, Agenda 21 from the United Nations Summit in 1992 on Sustainable Development, and ISO 9001 / 14001 / 19001 (Green Globe, n.d., a). Green Globe has provided certifications to hotel properties, cruise lines, conference centers, and tourism companies that become sustainable (Green Globe, n.d., b). The criteria and guidelines presented by CERES, GSTC, and Green Globe were incorporated into the survey in order to represent the ideas and standards that have been developed by hospitality organizations that focus on the environment and sustainability.

\section{Data Collection}

The survey process was started on June 1, 2014, and was administered through June 30, 2014. The questionnaire was conducted online through cruise message boards and on social media. Cruise message boards were chosen since they are online destinations for consumers who are new to cruising or have an interest in cruising. The survey was posted on Cruise Critic since the message board is one of larger cruise community groups online with over three million monthly visitors to the website (Cruise Critic, n.d., a). The message board was created in 1995 for cruisers to ask questions and 
interact with one another. The Cruise Critic community caters to new and seasoned cruisers. Members of Cruise Critic are able to interact on a web forum and read reviews of cruises, ask questions, post comments to each other, or meet fellow cruisers. Cruise Critic allows board members the opportunities to partake in question and answer sessions with cruise industry leaders (Cruise Critic, n.d., b). Cruisemates was also a similar message board to Cruise Critic. Information and news stories are provided to consumers on the main webpage and a forum is provided for consumers to interact. Cruisemates is an independent community, which was not affiliated with any cruise line or travel agency (Cruisemates, n.d.).

Message boards like Cruise Critic and Cruisemates are able to provide consumers a place to come together and discuss cruising. Message boards cater towards a wide range of people from different backgrounds. After examining postings on the cruise message boards, message board participants primarily list their location of living in the United States. Participants outside the United States were primarily noted to live in locations in Australia, Canada, New Zealand, and the United Kingdom. It was noted that travel experiences ranged for participants, from board members stating they were new cruisers to other members listing over 30 cruises traveled on in their board signatures. Cruise message board participants are from diverse backgrounds, which enabled the survey to question individuals from different social and economic environments. The instrument was posted on two cruise message boards: cruisecritic.com and cruisemates.com. The survey was posted on different cruise message boards to reach different consumers who may only frequent one cruise message board. In addition to posting on two cruise message boards, the survey was posted on the social media website Facebook. The 
researcher posted the survey in the comment section of Carnival Cruises, Celebrity Cruises, Norwegian Cruise Line, Princess Cruises, and Royal Caribbean International. This enabled consumers who followed and read through user comments on cruise line pages to find the survey. By posting the survey on Facebook, this reached other consumers who may not access cruise message boards and allowed the survey to reach a wider population of consumers.

The survey was conducted with Qualtrics Survey Software. A posting was uploaded with a link to the questionnaire on Cruise Critic, Cruise Mates, and Facebook. Respondents expressed their consent to participate in the survey by clicking the survey link provided to them in the forum and social media posting. The post on Cruise Critic, Cruise Mates, and Facebook informed participants that they could stop the process at any time, if they did not wish to continue with the survey. Survey participants were told the questionnaire related to the topics of the cruise industry and sustainability. The instrument was broken into five parts that addressed cruise background, view of sustainability, sustainable travel consumer behavior, importance of cruise line sustainability, and demographics. There were a total of 69 items in the survey for participants to answer. The researcher estimated the survey time to take between 10 to 15 minutes.

Each section of the instrument served a purpose to examine consumer backgrounds and consumer views towards sustainability. Section A was the first part of the survey on cruise background. There were 21 items to be answered in this section of the survey that focused on the number of cruises, preferred cruise line, and factors of importance for booking a cruise. A1 asked the number of cruises the consumer had taken. 
A2 examined preferred cruise line for the consumer. In A1 if a consumer selected have not cruised, A2 then asked which cruise line the consumer was interested to sail on for the first time. In A1 if a consumer selected one or more cruises, A2 asked the consumer their preferred cruise line to sail with. A3 through A21 were questions regarding factors for booking cruises. Consumers were able to choose from an importance five-point likert scale: unimportant, of little importance, moderately important, important, and very important. Examining the cruise background of consumers was important, because it helped to identify differences between new cruisers and cruisers who have cruised previously.

Section B of the questionnaire focused on sustainability and how the consumer may view sustainability. There were ten items for consumers to answer. Question B1 focused on the idea of sustainability and what it meant to the consumer. Five sustainable points were listed, and the consumer selected the points that they felt were the ideas of sustainability. Question B2 included eight major cruise lines to score on sustainability. Consumers were given the option to score cruise lines from one to ten on sustainable practices. One was the lowest for practicing sustainability and ten was the highest for practicing sustainability. Consumers were also given the option of stating no opinion for B2. Question B3 asked consumers if they believed the cruise industry was sustainable. Section $\mathrm{C}$ of the questionnaire focused on sustainable travel consumer behavior. The information presented by CERES in the Green Hotel Initiative was used to create parts of this section of the survey. In addition, the basic concepts of buy, stay, and purchase local were included in the questions. There was a total of nine items to be answered regarding consumer sustainable travel behavior. Survey participants were able 
to choose from an agreement five-point likert scale: strongly disagree, disagree, neither agree nor disagree, agree, and strongly agree. The choice of agreement for this scale was chosen since this section focused on individual behavior and how the consumer agreed with this behavior. It was important to have a basic understanding of the consumer's sustainable behavior and thoughts about their own practices.

The importance of this study focused on the perceptions of consumers towards cruise line sustainability. Section D of the questionnaire examined cruise ships and cruise lines. Consumers answered questions on how sustainable factors influenced their choice when choosing a cruise line. This section of the survey was created from the criteria presented by CERES in the Green Hotel Initiative, criteria set by the Global Sustainable Tourism Council for hotels and tour operators, and the certification standards presented by Green Globe. There were four sections of sustainability for consumers to answer. Questions D1 through D8 focused on the sustainable pillar of the environment. The questions examined renewable finishes, alternative transportations, energy saving devices, and waste issues. Questions D9 through D13 were regarding the economic pillar of sustainability. The questions examined hiring, living wages, purchasing policies, and supporting local businesses. Questions D14 through D20 focused on the social pillar of sustainability. The questions examined social issues in ports, safety precautions, legal protections, supporting local communities, and preservation issues. The first three areas of exploration in section D of the survey were based on the three pillars of sustainability. Question D21 through D23 covered general topics of regulations, management plans, and choosing a sustainable cruise line. Consumers chose from an importance five-point likert scale: unimportant, of little importance, moderately important, important, and very 
important. This section of the survey examined how certain sustainable topics may influence the consumer when choosing a cruise line, which was essential to examine to gain insight in consumer perceptions of sustainability in the cruise industry.

Section E was the fifth and final section of the survey, which examined demographics. The purpose of the demographics section was to find out population information about cruise consumers. There were a total of six demographic questions to be answered from gender, age, ethnicity origin, location, average annual household income, and highest education level achieved. Question E4 focused on the type of environment the consumer lived in. Consumers were given the choice of three community living choices to select: urban, suburban, and rural. Demographics were important to examine in order to compare the different survey participants to see how individual backgrounds may affect their answers. This helped to determine any trends based on demographics that emerged. Appendix A includes the survey instrument that was posted on the cruise message boards for cruise consumers to answer.

\section{Reliability and Validity}

In research studies it is important to establish trustworthiness and creditability, which is why reliability and validity are essential in establishing these factors when creating and implementing a research project. To test the reliability and validity of the instrument, a pilot study was conducted in a classroom at the Chaplin School of Hospitality and Tourism Management. The purpose of conducting the survey with students first was to determine if the questions were clear for participants to answer. This helped to determine if the questions provided to consumers would produce information 
regarding consumer perceptions of sustainability in the cruise industry. Once the students finished the questionnaire, the researcher sought out student thoughts and opinions on the instrument. This helped in understanding the potential responses the survey would possibly receive from participants and if the responses would be sufficient for a study on consumer perceptions. In addition to testing the reliability and validity of the instrument with a pilot test, the survey was sent to Guido Bauer and Bradley Cox of Green Globe. The purpose of sending the survey to Green Globe was to have sustainability experts review the questionnaire for their expert opinion. This allowed the researcher to find if there were any potential issues with the instrument and if any additional topics of sustainable cruising needed to be added.

The sample of consumers was also important in creating reliability and validity for this research study. A sufficient sample size for the study was 300 participants. A total of 324 consumers opened the survey, with 267 consumers who completed the survey. The sample used was non-probability and convenience based. A limitation with convenience-based sampling was a lack of ability to generalize to the general population. The researcher solely examined the consumer perceptions of participants from cruise message boards and social media. Even though cruise message boards and social media reached a wide range of individuals, there was no way in predicting who would partake in the survey.

\section{Data Analysis}

When the survey period was completed on June 30,2014 , the data was then analyzed. At this point, the researcher believed the data was saturated and no new 
information could come from the survey process. The data from the surveys was then coded to help determine consumer perceptions and any trends that would emerge. In the cruise background section, the coding for the first question regarding number of cruises started at zero for no cruises and ended at nine with 35 plus cruises. The cruise lines were then coded from one to twelve, with the no preference option coded as zero. In the factors for booking a cruise, unimportant was coded as one, of little importance as two, moderately important as three, important as four, and very important as five. The sustainability section included three separate questions. The question on sustainability meaning was coded from one to five, with one as purchasing and using local products and five as using environmentally friendly products. In the cruise line score question, codes ranged from one to ten depending on the choice answered by the consumer. If the consumer answered no opinion, a zero was coded. In the overall cruise sustainable question, no was coded as one, yes was coded as two, and no opinion was coded as zero.

For consumer behavior in section three of the survey, consumers chose an answer of agreement from a five-point likert scale. The data was coded from one to five with strongly disagree as one, disagree as two, neither agree nor disagree as three, agree as four, and strongly agree as five. For section four of the survey on sustainable factors when choosing a cruise line, consumers chose an answer of importance from a five-point likert scale. The data was coded from one to five with unimportant as one, of little importance as two, moderately important as three, important as four, and very important as five. In demographics all sections started with a one. Gender was coded with male as one and female as two. Age group was coded from one to six. Ethnicity origin and race was coded from one to seven. Living category was coded with rural as one, suburban as 
two, and urban as three. Average annual household income was coded from one to seven. Highest education level achieved was coded from one to eight. All questions in demographics with the phrase prefer not to answer were coded with zero. By coding the survey answers it helped to determine any overlaying concepts expressed by consumers on cruise message boards and social media. Once the coding was completed and the research had been inputted into SPSS, the researcher was able to identify any patterns and trends that emerged from the survey. 


\section{CHAPTER IV: RESULTS}

The goal of this study was to identify perceptions of consumers on sustainability in the cruise industry. The study sought to understand the factors that influenced booking a cruise and the sustainable factors that influenced a consumer to choose a cruise line. The researcher used a structured survey to investigate consumer ideas and preferences. The survey reached out to consumers on cruise message boards and social media who cruised or had an interest in cruising. Once the survey period ended on June 30, 2014, with a total of 267 consumers who completed the survey, the researcher felt data saturation was achieved. The researcher then coded and inputted the data into SPSS.

After the data was tested in SPSS, the researcher noticed patterns that emerged from the study. The proceeding chapter summarizes the data collection process and the findings of the survey. The findings follow the order of the research questions, which are stated again:

1. What factors influence a consumer to book a cruise?

2. What sustainable factors are important to consumers when choosing a future cruise?

3. How do consumers perceive environmental, social, and economic impacts of sustainability in the cruise industry?

4. Are there differences within demographics on consumer perceptions of cruise line sustainability? 


\section{Data Collection and Participant Population}

The survey participants were members of cruise message boards and social media. The researcher posted the link to the survey on Cruise Critic, Cruisemates, and Facebook. To ensure maximum variation of the data, the researcher felt it was important to post the survey on two different cruise message boards and social media. This was done in order to reach a wider audience of cruisers and consumers interested in cruising. Consumer participation in the survey was anonymous and voluntary. Any consumer who wanted to partake in the survey had to select the link in the forum posting or the Facebook post, which then took the consumer to the survey on Qualtrics.

The survey consisted of five types of questions. The first section addressed cruise background. For example question A1 asked, "how many times have you cruised?" The section also addressed the importance of specific factors for booking a cruise, such as activities, cost, destinations, and environmental friendliness. Once the first section of the survey was completed, section two asked consumers about their views of sustainability and cruise line sustainable practices. Question B2 asked consumers to score how they felt eight major cruise lines scored in sustainable practices. Section three asked questions about sustainable travel behavior for consumers. This section focused on how a consumer agreed with behaviors on sustainability. Section four of the survey addressed importance of cruise line sustainability. The section was broken into four parts: environmental sustainability, economic sustainability, social sustainability, and general sustainability. The first three parts of section four examined the three pillars of sustainability. The last part of this section focused on general items related to the idea of sustainability. The final 
section of the survey addressed basic demographic questions. There were a total of 69 items to be answered by survey participants.

\section{Demographics and Cruise Background}

Demographics. There were a total of six demographic questions to be answered.

The questions examined age, gender, race, environmental setting, income, and education. Of the 267 survey respondents, only 1.5 percent of respondents preferred not to answer on age. The age category of 18 to 25 percent received 5.2 percent response and the category of 26 to 35 received 11.2 percent response. The age category of 36 to 45 received 14.6 percent response and the category of 46 to 55 received 15.4 percent response. The age category of 55 to 65 received 29.2 percent response and the age category of 66 and older received 22.8 percent (see Figure 1).

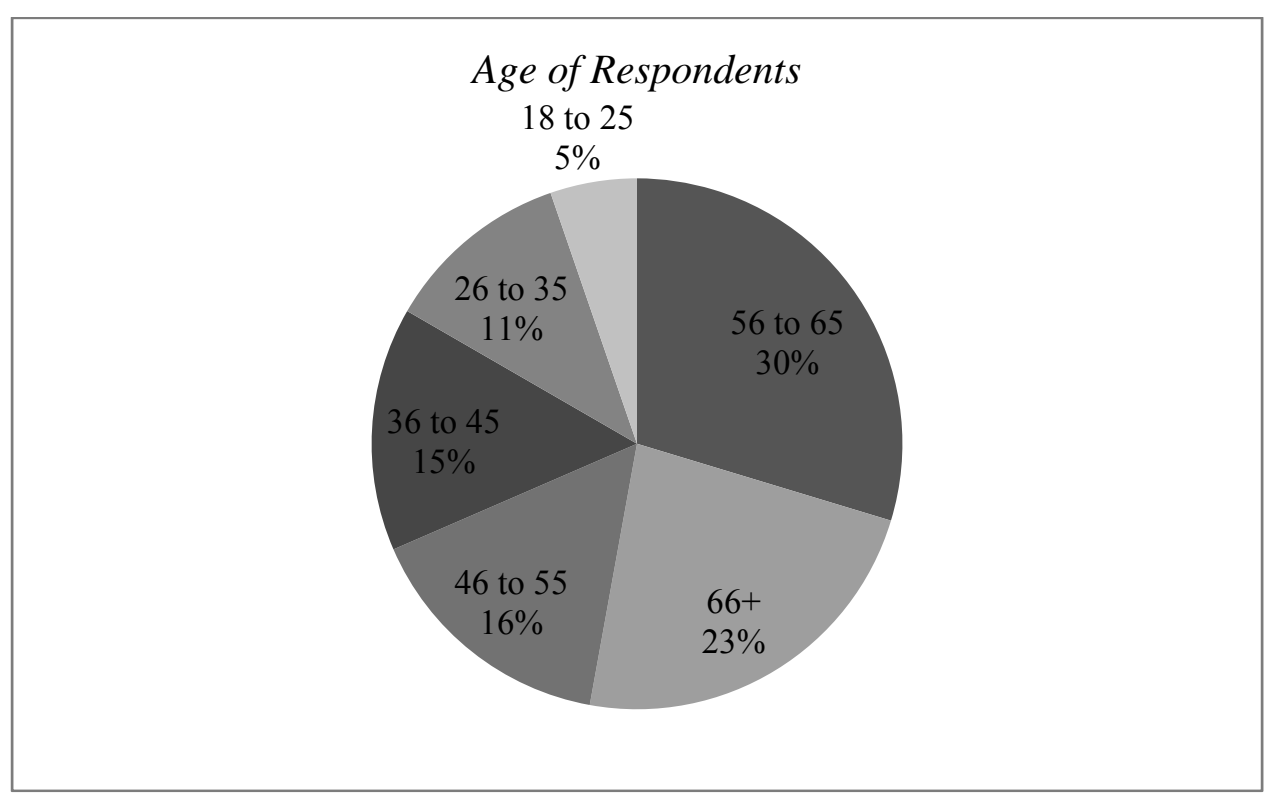

Figure 1. Percentage of age for respondents. The figure excludes the percentage of prefer not to answer, which 1.5 percent of respondents selected.

For gender, the responses for each category were equal with 50 percent of respondents identifying as male and 50 percent of respondents identifying as female. 
Only one respondent preferred not to identify gender in the survey. The category on ethnicity origin received the highest percentage of responses for Caucasian / White, with 88 percent of respondents selecting this category. The six different ethnicity categories received 9.0 percent of respondent selections and 2.2 percent of respondents selected prefer not to answer.

The question about environmental setting found 87 percent of respondents selected either suburban or urban environments for where they lived. For rural environment, 10.0 percent of respondents considered this as the environment they lived in. Three percent of respondents preferred not to answer on environmental setting.

For the average annual household income, 59.0 percent of respondents selected the income ranges of $\$ 60,000$ to $\$ 79,999, \$ 80,000$ to $\$ 99,999$, and $\$ 100,000$ to $\$ 149,999$ (see Figure 2).

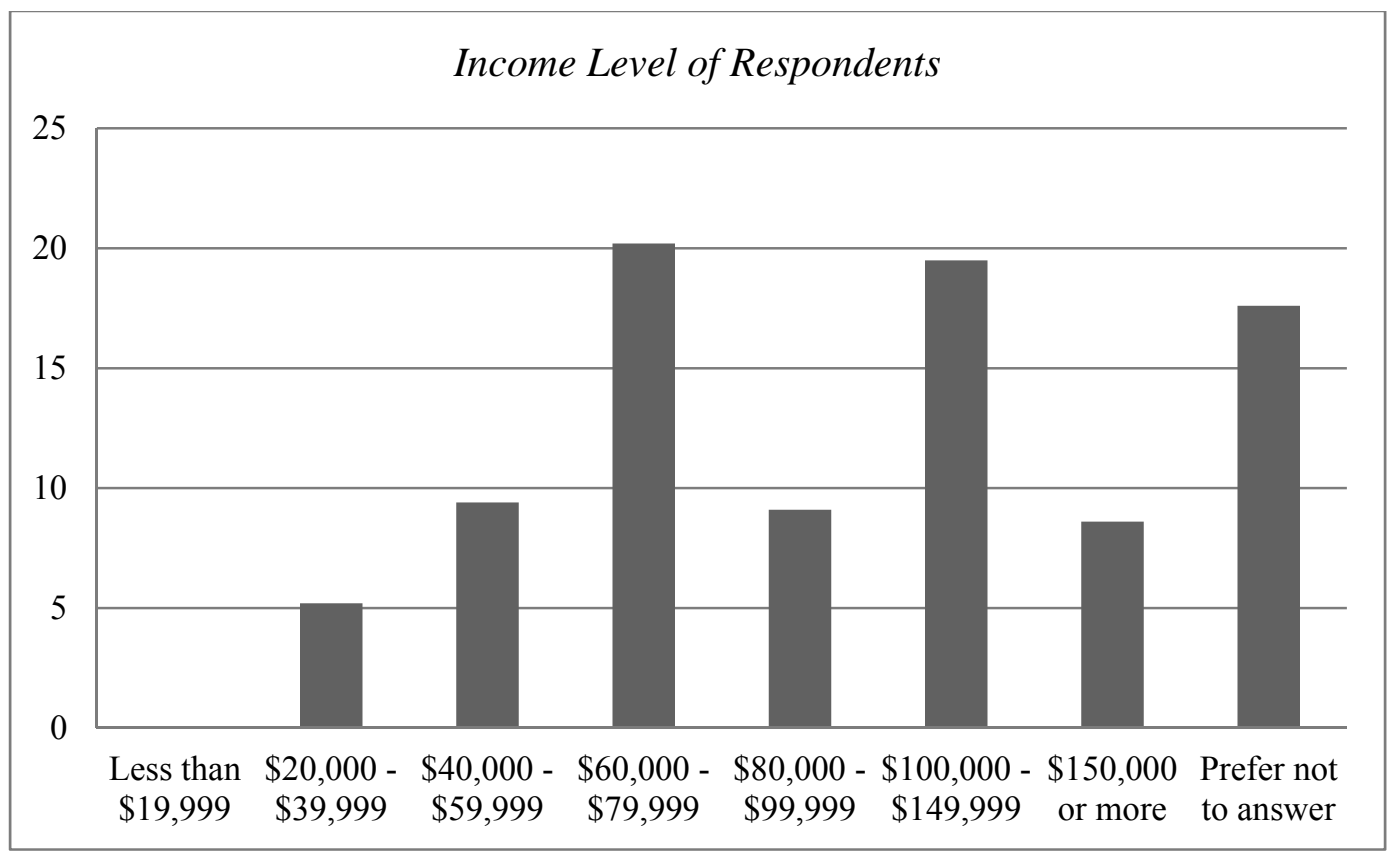

Figure 2. Percentage of income for respondent. The highest income level was $\$ 60,000$ to $\$ 79,999$, which received 20.2 percent of selection from respondents. 
The final demographics question on education levels found 35.0 percent of respondents had completed a bachelor's degree and 30.0 percent of respondents selected some postgraduate work, a graduate degree, or professional degree (see Figure 3).

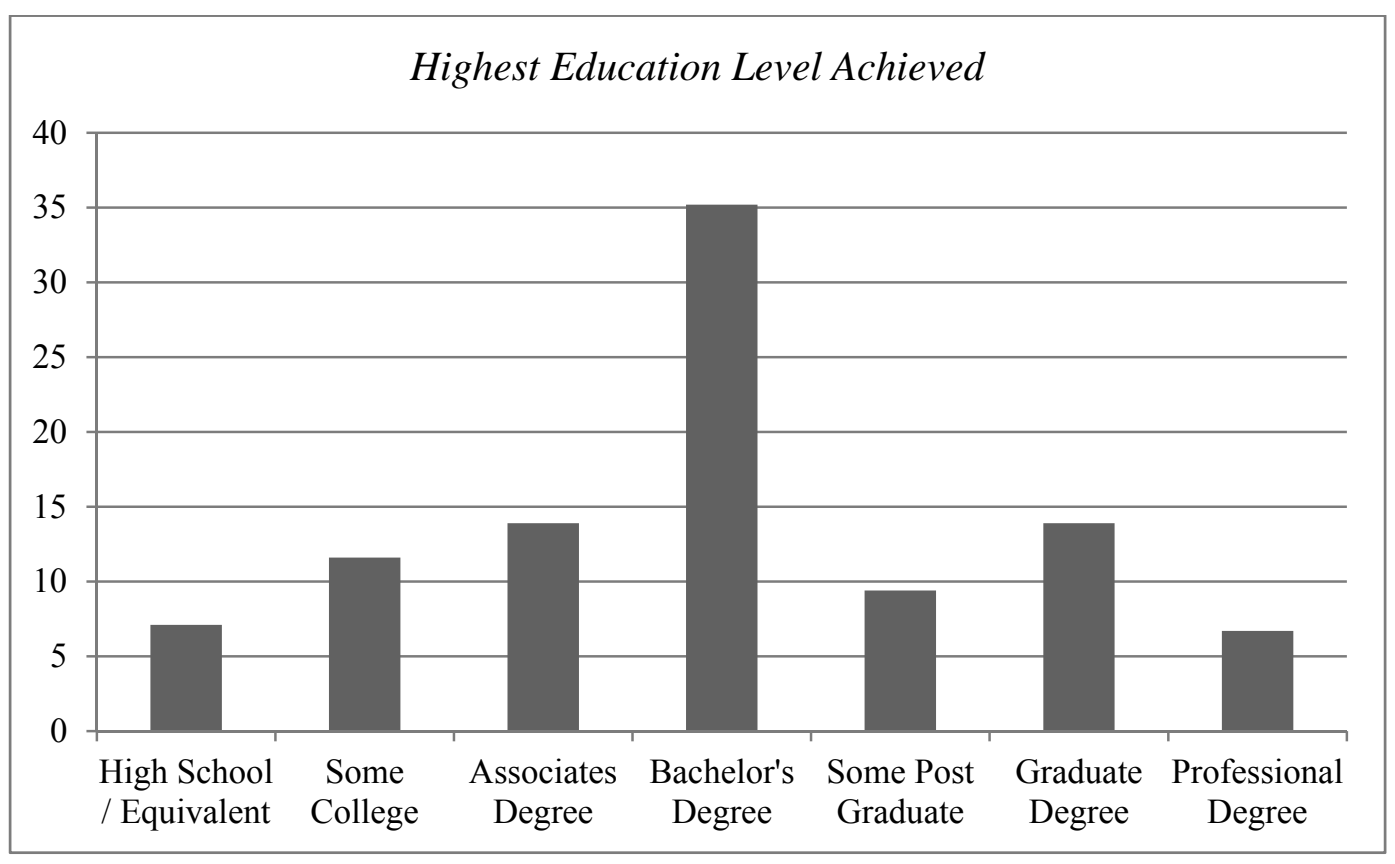

Figure 3. Percentage of highest education level achieved for respondents. The figure excludes the percentage of prefer not to answer, which 2.2 percent of respondents selected.

Cruise Background. Every survey began with two questions about cruise background to help the researcher understand consumer backgrounds in the cruise industry. Question A1 asked survey respondents how many times they had cruised. Of the 267 respondents, 11.2 percent of respondents had not cruised. A total of 5.2 percent had only cruised one time. Respondents who had cruised two to nine times contributed to 30.0 percent of the survey participants. A total of 33.0 percent of respondents selected 10 to 24 times. Respondents who had cruised 25 times or more were 20.6 percent of survey respondents (see Figure 4). 


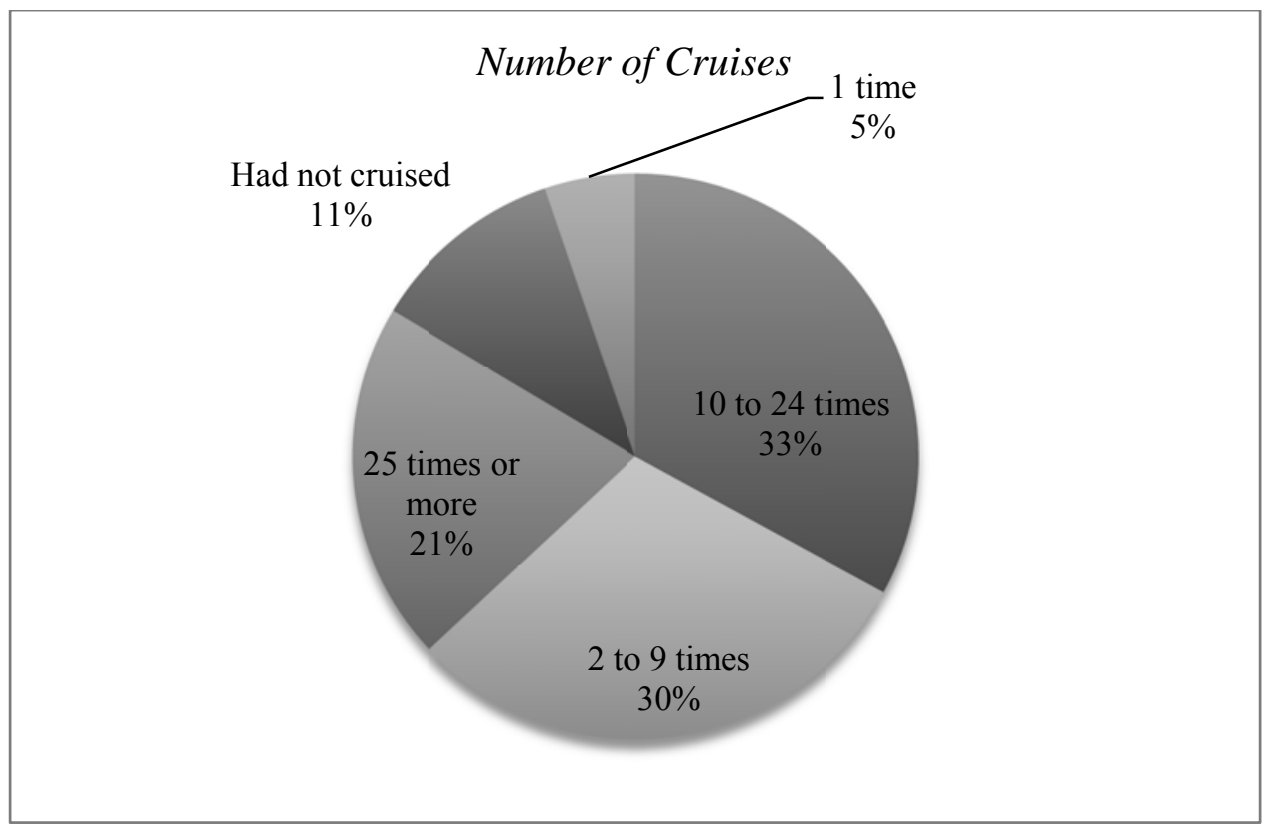

Figure 4. Percentage of number of cruises for respondents.

For respondents who had not previously cruised then answered which cruise line they would be most interested to sail on for the first time. The selection of no preference received the highest percentage of responses at 33.3 percent. The two cruise lines that received the highest interest were Carnival Cruises and Disney Cruise Line. Disney Cruise Line received 20.0 percent interest from respondents and Carnival Cruises received 16.7 percent interest from respondents. One respondent selected other for the cruise line they were interested to sail on for the first time. The respondent then wrote that he or she was interested to sail on Viking River Cruises.

For respondents who answered they had cruised previously then answered question A2 regarding their preferred cruise line to sail. Celebrity Cruises and Princess Cruises received the highest percentage of preference from respondents. P\&O Cruises, MSC Cruises, and Disney Cruise Line received the lowest amount of preference from survey respondents (see Table 1). Three survey respondents who had cruised previously 
did select other for their preferred cruise line. All three choices that were written by the three respondents were luxury cruise lines with ships that held less than 1000 cruisers. The three cruise lines listed were Azamara Club Cruises, Crystal Cruises, and Windstar Cruises.

Table 1. Preferred cruise line for respondents who have previously sailed

\begin{tabular}{|c|c|c|}
\hline & Frequency & Percent \\
\hline Princess Cruises & 60 & 25.3 \\
\hline Celebrity Cruises & 49 & 20.7 \\
\hline Royal Caribbean Int. & 29 & 12.2 \\
\hline Carnival Cruises & 28 & 11.8 \\
\hline Holland America Line & 24 & 10.1 \\
\hline Norwegian Cruise Line & 14 & 5.9 \\
\hline Cunard & 10 & 4.2 \\
\hline No Preference & 8 & 3.4 \\
\hline Disney Cruise Line & 7 & 3.0 \\
\hline MSC Cruises & 3 & 1.3 \\
\hline Other & 3 & 1.3 \\
\hline P\&O Cruises & 2 & 0.8 \\
\hline Costa Cruises & 0 & 0.0 \\
\hline
\end{tabular}

\section{Research Question One}

The following section summarizes the major themes that emerged from research question one. Research question one sought to answer the factors that influence a consumer to book a cruise. In addition, hypothesis one and hypothesis two sought to discover if price and destination were more important than environmental friendliness. Each respondent was asked 19 points on factors when booking a cruise. The factors examined specific areas of cruising from cost, cruise line, destinations, environmental friendliness, and sightseeing. The percentages of responses for all 19 factors are listed in the table below (see Table 2). 
Table 2. Importance of factors for survey respondents when booking a cruise

\begin{tabular}{|c|c|c|c|c|c|c|}
\hline \multicolumn{7}{|c|}{$\begin{array}{l}\text { Percentage of responses from survey respondents, with one as unimportant and five as } \\
\text { very important }\end{array}$} \\
\hline & $\begin{array}{c}\text { No } \\
\text { Opinion }\end{array}$ & $\underline{1}$ & $\underline{2}$ & $\underline{3}$ & $\underline{4}$ & $\underline{5}$ \\
\hline $\begin{array}{l}\text { Accessibility } \\
\text { for disabilities }\end{array}$ & 0.4 & 28.1 & 31.8 & 21.3 & 9.4 & 9.0 \\
\hline Activities & 0.7 & 2.2 & 5.2 & 18.0 & 51.7 & 22.1 \\
\hline Class of ship & 0.7 & 2.6 & 7.5 & 47.6 & 20.6 & 21.0 \\
\hline Cost & 1.1 & 0.4 & 3.0 & 22.5 & 33.7 & 39.3 \\
\hline Cruise line & 0.7 & 1.9 & 3.7 & 41.6 & 20.6 & 31.5 \\
\hline Cuisine & 0.7 & 1.1 & 1.1 & 19.5 & 46.1 & 31.5 \\
\hline $\begin{array}{l}\text { Environmental } \\
\text { friendliness }\end{array}$ & 0.4 & 2.6 & 8.6 & 29.2 & 41.6 & 17.6 \\
\hline $\begin{array}{l}\text { Experiencing } \\
\text { local cultures }\end{array}$ & 0.7 & 2.6 & 9.0 & 19.5 & 47.6 & 20.6 \\
\hline Getting away & 1.5 & 0.7 & 1.9 & 27.7 & 37.8 & 30.3 \\
\hline Itinerary & 0.4 & 0.7 & 3.0 & 18.7 & 35.6 & 41.6 \\
\hline $\begin{array}{l}\text { Length of } \\
\text { cruise }\end{array}$ & 1.1 & 0.4 & 2.2 & 50.9 & 26.6 & 18.7 \\
\hline $\begin{array}{l}\text { Location of } \\
\text { embarkation } \\
\text { and } \\
\text { disembarkation }\end{array}$ & 1.5 & 0.4 & 3.0 & 23.6 & 46.4 & 25.1 \\
\hline Relaxation & 2.2 & 0.0 & 0.7 & 30.7 & 39.7 & 26.6 \\
\hline Shopping & 1.5 & 4.9 & 23.2 & 42.3 & 15.7 & 12.4 \\
\hline $\begin{array}{l}\text { Sightseeing } \\
\text { Archaeological } \\
\text { / Historical }\end{array}$ & 1.5 & 4.5 & 9.4 & 19.9 & 37.8 & 27.0 \\
\hline $\begin{array}{l}\text { Sightseeing } \\
\text { Nature }\end{array}$ & 1.9 & 4.9 & 3.7 & 24.0 & 39.3 & 26.2 \\
\hline $\begin{array}{l}\text { Spending time } \\
\text { with friends } \\
\text { and family }\end{array}$ & 2.2 & 3.7 & 4.5 & 40.4 & 29.2 & 19.9 \\
\hline $\begin{array}{l}\text { Trying new } \\
\text { experiences }\end{array}$ & 1.9 & 0.0 & 2.2 & 21.3 & 47.6 & 27.0 \\
\hline $\begin{array}{l}\text { Water } \\
\text { activities in } \\
\text { port }\end{array}$ & 1.5 & 5.6 & 19.5 & 25.8 & 29.2 & 18.4 \\
\hline
\end{tabular}


Out of the 19 points on factors for booking a cruise, many of the survey respondents answered moderately important, important, and very important to the cruise booking factors. Itinerary, A12, received highest preference from consumers with a mean of 4.13. Cost of the cruise, A6, received the second highest preference from consumers. The factor of cuisine, A8, was the third highest preference for consumers with a mean of 4.03. Cuisine had a large impact for respondents when booking a cruise with 77.6 percent of consumers who felt cuisine was an important or very important factor. No survey respondents selected the choice of unimportant for the booking factors of A15 and A20: relaxation and trying new experiences. Respondents placed a low importance on shopping, A16. Shopping received a mean of 3.03 with 23.2 percent of respondents who selected of little importance and 42.3 percent who selected moderately important. The third least important factor for respondents was water activities in port, A21. Water activities had a mean of 3.31 with 55 percent of consumers either selecting moderately important or important.

Hypothesis One. For hypothesis one, the researcher predicted the price of a cruise would be more important than environmental friendliness. Table 2 above lists the frequency of respondent selections for cost of a cruise and environmental friendliness. A t-test was conducted to compare cost of a cruise and environmental friendliness. There was a significant difference in the scores for cost of a cruise $(m=4.05, s d=.976)$ and environmental friendliness $(m=3.62, s d=.983) ; t(266)=-4.939, p=.000$. Overall, cost received a higher preference than environmental friendliness. For the cost factor, 3.4 percent of respondents felt cost was unimportant or of little importance when selecting a cruise. This number increased for environmental friendliness with 11.2 percent of 
respondents selecting unimportant or of little importance. For the moderately important selection of booking a cruise, environmental friendliness did see a higher selection compared to cost. The cost of the cruise was 22.5 percent moderately important for respondents, while environmental friendliness was 29.2 percent moderately important. The difference between cost and environmental friendliness was most noted in the selection of important or very important. For cost, 73.0 percent of respondents felt cost was either important or very important for selecting a cruise. This percentage decreased for environmental friendliness, where 59.2 percent of respondents felt it was an important or very important factor for booking a cruise.

When consumers were asked their agreement level on $\mathrm{C} 8$, if they look for the best travel deals, the mean was 4.15 . The agreement score ranged from one as strongly disagree to five as strongly agree. The minimum selection by consumers was a two for this question with disagrees, since no consumers selected strongly disagree on seeking the best travel deals. On the agreement selection 44.0 percent of consumers selected agree and 36.0 percent selected strongly disagrees. Consumers were next asked their agreement level on $\mathrm{C}$, if they were willing to pay slightly more for a hotel and tourism operator that engages in sustainable practices. The mean score for this question was 3.26 with a minimum of one on strongly disagrees and a maximum of five as strongly agrees. On the agreement selection 18.0 percent of consumers selected disagree, 42.0 percent of consumers selected neither agree nor disagreed, and 27.0 percent selected agree.

Hypothesis Two. For hypothesis two, the researcher predicted environmental friendliness would not be as important to a consumer as the destination of the cruise. Table 2 above lists the frequency of respondent selections for environmental friendliness 
and itinerary. A t-test was conducted to compare itinerary and environmental friendliness. There was a significant difference in the scores for itinerary $(m=4.13, s d=.914)$ and environmental friendliness $(m=3.62, s d=.983) ; t(266)=-6.544, p=.000$. The destination of a cruise received a higher preference of importance than environmental friendliness. A small percentage of respondents felt itinerary was unimportant or of little importance for booking a cruise. A total of 3.7 percent of respondents selected unimportant or of little importance. The number increased for environmental friendliness with 11.2 percent of respondents feeling it was an unimportant or of little importance factor when booking a cruise. For the moderately important selection of booking a cruise, environmental friendliness did see a higher selection compared to itinerary. The itinerary saw 18.7 percent of respondents finding the factor of itinerary to be moderately important, while environmental friendliness was moderately important for 29.2 percent of respondents. The difference between environmental friendliness and itinerary was most noted in the selection of important or very important. Environmental friendliness was important or very important for 59.2 percent of respondents when booking a cruise. The percentage of respondents increased for itinerary, with 77.2 percent of respondents feeling it was an important or very important factor when booking a cruise.

\section{Research Question Two}

The following section summarizes the major themes that emerged from research question two. Research question two sought to answer the sustainable factors that are important to consumers when choosing a future cruise. Before survey respondents answered questions on sustainable factors, respondents were first asked about their 
agreement level with sustainable travel behaviors. The two highest preferred sustainable travel behaviors could be considered both economic and social. The sustainable travel behavior respondents identified the most with was, "when I travel I try to eat at locally owned restaurants.” The mean for responses was 3.95 with 44.5 percent of respondents agreeing with the statement and 28.5 strongly agreeing. The second sustainable travel behavior consumers agreed with was, "when I travel I try to purchase local products." The mean for responses was 3.88 with 56.2 percent agreement and 18.7 percent strong agreement.

Consumers responded to the point, "when I travel I try to eat at restaurants that are familiar (chain restaurants)." The mean for responses was 2.67 with 39.3 percent of respondents who disagreed and 34.1 percent who selected neither agree or disagree. The second and third lowest sustainable travel behaviors related to the environment. For the point "when I travel I am willing to reuse my towel or bed linens" the mean was 2.74 , which was the second lowest sustainable travel behavior selected by respondents. For the agreement level of strongly disagrees, 15.6 percent of respondents selected this option and for the point of disagrees 37.5 percent of respondents selected this agreement level. The third lowest sustainable travel behavior was "when I travel I try to stay at a hotel that is considered 'green." The mean for this behavior point was 3.07 with 22.5 percent of respondents selecting disagree and 53.2 percent selecting neither agree nor disagree.

In the survey consumers answered a series of questions about the importance of sustainable factors when choosing a cruise line. Each respondent was asked 23 points on sustainable factors when choosing a cruise line. The factors examined specific areas of environmental, economic, and social sustainability. Respondents were also asked three 
general sustainable factors. The factor "cruise lines observe all applicable regulations in port and international waters" was the most important of the three general factors with a mean of 4.01. No respondents selected the point of unimportant for this factor. The point of importance was selected by 35.6 percent of respondents and very important was selected by 34.8 percent. The factor regarding "a long-term management plan for sustainability has been developed and implemented" received a mean of 3.53 with 41.6 percent of respondents selecting moderately important. When respondents were asked if they would choose one cruise line over another because it is considered more sustainable, only 11.2 percent said this was very important. The factor received a mean of 3.29 with 43.1 percent of respondents selecting moderately important.

Respondents were asked eight points on environmental sustainability. The lowest mean for environmental sustainability was 2.85 for the factor of "room card reader for passengers to insert their cruise cards when entering a cabin to turn on electricity." While 11.2 percent of respondents selected unimportant, 24.0 percent selected of little importance, and 40.1 percent selected moderately important. The second lowest mean for environmental sustainability was 3.00 for the factor of "green and sustainable certifications." With 50.9 percent of respondents who selected the point of moderately important and 21.3 percent selected the point of little importance. The second highest mean for environmental sustainability was 3.36 for the factor of "use of renewable energy sources." With 49.8 percent of respondents who selected moderately important, 13.9 percent who selected important, and 20.2 percent that selected very important. The highest mean was 3.58 for the factor of "preferences for products that are environmentally responsible.” The point of moderately important was selected by 34.1 
percent of respondents; important was selected by 41.6 percent of respondents; and very important was selected by 14.2 percent of respondents.

The second section respondents answered was regarding economic sustainability. There were five factors for respondents to answer. The lowest mean for economic sustainability was 3.52 for the factor of "cruise lines hire local minorities and women." The point of moderately important received 42.3 percent of responses, while the point of important received 25.8 percent, and very important received 21.3 percent. The second lowest mean for economic sustainability was 3.57 for the factor of "cruise lines give local residents the opportunity to gain employment." The point of moderately important received 43.1 percent of responses, while the point of important received 30.7 percent, and very important received 18.4 percent. The second highest mean for economic sustainability was 3.71 for the factor of "cruise lines support local businesses selling sustainable products that represent a destination's culture, history, and nature." The point of moderately important received 30.3 percent of responses, important received 43.1 percent, and very important received 19.1 percent. The highest mean for economic sustainability was 3.73 for the factor of "purchasing policies favor local goods from embarkation ports and ports traveled to throughout a cruise." The point of important received 40.1 percent of responses and very important received 21.0 percent.

The third section respondents answered was regarding social sustainability. There were seven factors for respondents to answer. The lowest mean for social sustainability was 3.77 for the factor of "cruise lines contribute to the preservation of historical and archaeological sites." The point of moderately important was selected by 28.1 percent of respondents and important was selected by 41.9 percent. The second lowest mean for 
social sustainability was 3.81 for the factor of "cruise lines support communities traveled to with projects supporting development of communities and infrastructure." The point of moderately important was selected by 21.3 percent of respondents and important was selected by 55.4 percent. The second highest mean for social sustainability was 4.03 for two factors: "international legal protection is provided to crew" and "information provided to passengers about local cultures and customs of destinations." For the point of international legal protection, 44.9 percent of respondents selected this was important and 31.5 percent selected very important. For the point of information provided to passengers, 53.6 percent of respondents selected this was important and 27.3 selected very important. The highest mean for social sustainability was 4.49 for the factor of "all applicable health and safety measures are taken to protect passengers, crew, and local communities." No respondents selected the point of unimportant. The point of very important was selected by 58.1 percent of respondents and important was selected by 34.8 percent.

\section{Research Question Three}

The following section summarizes the major themes that emerged from research question three. Research question three sought to answer how consumers perceive sustainability in the cruise industry. The researcher first noted there were differences in how survey participants viewed sustainability. Question B1 asked consumers what sustainability meant to them. A majority of consumers, 81.6 percent, felt sustainability meant conserving resources around them. Purchasing and using local products received 74.9 percent response from consumers stating they felt this was a sustainable point. Only 62.2 percent of survey respondents felt using environmentally friendly products related to 
what sustainability meant to them. On the factor of respecting native populations, only 58.4 percent of participants felt this was a sustainable principle. For point of earning a living wage, only 31.8 percent of respondents thought this was a sustainable point. Overall 68.2 percent of consumers did not feel earning a living wage meant sustainability.

The researcher next examined how consumers felt the cruise industry was doing overall on sustainability. Question B3 asked consumers if they felt the cruise industry was sustainable. Overall, 65.9 percent of consumers felt the cruise industry was sustainable. This was significant since 15.0 percent of consumers did not feel the industry was sustainable. A total of 19.1 percent of respondents had no opinion on cruise industry sustainability. The researcher further analyzed this question by looking at cruise history. The factor of cruise history had a significant affect on some of the sustainable factors. An analysis of variance showed the effect was significant, $f(9,257)=6.321, p=.000$. Post hoc analyses using the Scheffe post hoc criterion showed respondents who had cruised more, were more likely to find the cruise industry sustainable. For respondents who had cruised 25 times or more, 74.5 percent felt the cruise industry was sustainable while 20.0 percent did not. For respondents who had cruised 10 to 24 times, 79.5 percent felt the cruise industry was sustainable while 13.6 percent did not. The percentage slightly decreased for participants who had cruised two to nine times with 62.2 percent selecting the cruise industry was sustainable, 13.8 percent selected the industry was not sustainable, and 25.0 percent had no opinion. For respondents who had only cruised once or had not cruised, the percentage of respondents who felt the cruise industry was sustainable decreased compared to respondents who had cruised more. Respondents who 
had not cruised, 36.7 percent thought the cruise industry was sustainable, while 50.0 percent had no opinion and only 13.3 percent thought the industry was not sustainable. For the participants who had only cruised once, 35.7 percent thought the industry was sustainable, while 14.3 percent thought the industry was not sustainable, and 50.0 percent had no opinion. The responses for cruise industry sustainability are listed in the table below (see Table 3).

Table 3. Percent of respondents scores for cruise industry sustainability

\begin{tabular}{|c|c|c|c|}
\hline \multicolumn{4}{|c|}{ Consumers were asked if they thought the cruise industry was sustainable } \\
\hline & $\underline{\text { Yes }}$ & $\underline{\text { No }}$ & No Opinion \\
\hline All Respondents & 65.9 & 15.0 & 19.1 \\
\hline $\begin{array}{l}\text { Respondents who have not cruised or } \\
\text { cruised once }\end{array}$ & 35.7 & 14.3 & 50.0 \\
\hline Respondents who cruised 2 to 9 times & 62.2 & 13.8 & 25.0 \\
\hline Respondents who cruised 10 to 24 times & 79.5 & 13.6 & 6.9 \\
\hline $\begin{array}{l}\text { Respondents who cruised } 25 \text { times or } \\
\text { more }\end{array}$ & 74.5 & 20.0 & 5.5 \\
\hline
\end{tabular}

When it came to survey participants scoring individual cruise lines in question B2 for how they felt each line did on sustainability, many participants had no opinion. Overall most cruise lines had 100 survey respondents state no opinion. Princess Cruises was the only line to receive 90 responses with no opinion. The highest no opinion received was for MSC Cruises with 82.8 percent of respondents who selected no opinion. MSC Cruises received no scores from survey participants of a nine or ten on sustainability. Respondents mostly favored Celebrity Cruises and Princess Cruises for sustainability. Celebrity Cruises received a mean of 6.26 and 40.8 percent of respondents who selected a score of six or higher on sustainability. Princess Cruises received the highest number of responses with 53.6 percent of respondents who selected a score of six 
or higher on sustainability and the mean was 6.97 . Three cruise lines received a mean between 5.00 and 6.00: Disney Cruise Line received a mean of 5.78; Royal Caribbean International received a mean of 5.50; and Holland America Line received a mean of 5.35. Norwegian Cruise line received a mean of 4.80. Carnival Cruises received the highest number of low scores on sustainability with 34.4 percent of respondents who selected a score of five or lower with a mean of 4.25. Overall MSC Cruises received the lowest mean of 3.91. The responses for all eight cruise lines on sustainability scores from respondents are listed in the table below (see Table 4).

Table 4. Respondent scores for cruise lines sustainability

\begin{tabular}{|c|c|c|c|c|c|c|c|c|c|c|c|}
\hline \multicolumn{12}{|c|}{ Percent of responses from survey respondents for sustainability scores from 1 to 10} \\
\hline & $\frac{\text { No }}{\text { Opinion }}$ & 1 & $\underline{2}$ & $\underline{3}$ & $\underline{4}$ & $\underline{5}$ & $\underline{6}$ & $\underline{7}$ & $\underline{8}$ & $\underline{9}$ & $\underline{10}$ \\
\hline $\begin{array}{l}\text { Carnival } \\
\text { Cruises }\end{array}$ & 53.6 & 6.4 & 5.2 & 8.6 & 9.0 & 5.2 & 3.4 & 2.6 & 2.6 & 0.7 & 2.6 \\
\hline $\begin{array}{l}\text { Celebrity } \\
\text { Cruises }\end{array}$ & 39.7 & 1.5 & 2.6 & 2.6 & 4.5 & 8.2 & 9.0 & 13.1 & 13.1 & 3.0 & 2.6 \\
\hline $\begin{array}{l}\text { Disney } \\
\text { Cruise Line }\end{array}$ & 82.4 & 0.7 & 2.6 & 0.7 & 1.5 & 2.2 & 2.6 & 2.2 & 1.5 & 0.7 & 2.6 \\
\hline $\begin{array}{l}\text { Holland } \\
\text { American } \\
\text { Line }\end{array}$ & 56.6 & 1.5 & 3.7 & 3.0 & 7.1 & 7.5 & 8.2 & 6.4 & 2.2 & 0.7 & 3.0 \\
\hline $\begin{array}{l}\text { MSC } \\
\text { Cruises }\end{array}$ & 82.8 & 3.7 & 1.1 & 3.0 & 2.2 & 3.0 & 1.5 & 1.5 & 1.1 & 0.0 & 0.0 \\
\hline $\begin{array}{l}\text { Norwegian } \\
\text { Cruise Line }\end{array}$ & 71.9 & 3.4 & 2.2 & 3.4 & 3.0 & 6.7 & 2.6 & 1.5 & 3.4 & 0.7 & 1.1 \\
\hline $\begin{array}{l}\text { Princess } \\
\text { Cruises }\end{array}$ & 33.7 & 1.1 & 1.9 & 1.9 & 2.6 & 5.2 & 6.4 & 17.6 & 18.4 & 5.6 & 5.6 \\
\hline $\begin{array}{l}\text { Royal } \\
\text { Caribbean }\end{array}$ & 49.8 & 1.9 & 5.2 & 4.1 & 4.1 & 8.6 & 9.7 & 7.5 & 3.0 & 2.6 & 3.4 \\
\hline
\end{tabular}

\section{Research Question Four}

The following section summarizes the major themes that emerged from research question four. Research question four sought to answer if there are differences within 
demographics on consumer perceptions of cruise line sustainability. In addition, hypothesis one and hypothesis two sought to discover if there were differences between gender and age. The researcher first examined how the demographic of income affected results on consumer perceptions.

The factor of income had a significant effect on some of the sustainable factors. An analysis of variance showed the effect of "access to alternative modes of transportation in ports" was significant, $f(5,213)=3.782, p=.003$. Post hoc analyses using the Tukey post hoc criterion for significance indicated that the income levels from $\$ 40,000$ to $\$ 149,999$ placed a higher importance for "access to alternative modes of transportation in ports" compared to the income level of $\$ 150,000$ or more. An analysis of variance showed the effect of "composting of food waste" was significant, $f(5,213)=$ $4.379, p=.001$. Post hoc analyses using the Scheffe post hoc criterion for significance indicated that the income level of $\$ 100,000$ or more placed a higher importance on "composting of food waste" compared to the income level of $\$ 40,000$ to $\$ 59,999$. All three factors of general sustainability showed in an analysis of variance a significant effect. The factor of "a long-term management plan for sustainability" was significant, $f$ $(5,213)=3.377, p=.006$. In the post hoc analyses using the Tukey post hoc criterion for significance indicated the income level of $\$ 80,000$ or more placed a higher importance on this factor compared to the income level of $\$ 40,000$ to $\$ 59,999$. The factor of "cruise lines observe all applicable regulations" was significant, $f(5,213)=3.045, p=.011$. In the post hoc analyses using the Tukey post hoc criterion for significance indicated the income level of $\$ 100,000$ or more placed a higher importance on this factor compared to the income level of $\$ 40,000$ to $\$ 59,999$. The factor of choosing one cruise line over 
another because of sustainability was significant, $f(5,213)=3.544, p=.004$. When it came to the option of choosing one line over another due to sustainability, the post hoc analyses using the Tukey post hoc criterion for significance indicated the income level of $\$ 60,000$ or more placed a higher importance on this point compared to the income level of $\$ 40,000$ to $\$ 59,999$.

Hypothesis Three. For hypothesis three, the researcher predicted sustainable practices are more important to younger cruisers when choosing a cruise than older cruisers. In the survey there was no significant difference in 17 sustainable factors for choosing a cruise between young and older cruisers. Six of these points were environmental sustainability factors; three of these factors were economic sustainability factors; and five of these factors were social sustainability factors. When it came to the option of choosing one line over another due to sustainability, there was no significant difference between young and older cruisers. Additionally there was no significant difference between young and older cruisers on the questions about "a long-term management plan for sustainability has been developed and implemented" and "cruise lines observe all applicable regulations in port and in international waters."

There was a significant value of .05 and less for six sustainable factors. Two of these points were environmental sustainability factors; two of these factors were economic sustainability factors; and two of these factors were social sustainability factors. The two environmental sustainability factors varied on the impact of age. An analysis of variance showed the effect of "green and sustainable certifications" to be significant, $f(5,257)=3.537, p=.004$. Post hoc analyses using the Tukey post hoc criterion for significance indicated that the age level of 56 to 65 to be significantly higher 
than the age group 46 to 55 . The mean for the age group of 56 to 65 was 3.32, while the mean for the age group of 46 to 55 was 2.76 . An analysis of variance showed the effect of "access to alternative modes of transportation in ports" to be significant, $f(5,257)=$ $8.847, p=.000$. Post hoc analyses using the Tukey post hoc criterion for significance indicated that the age levels of 26 to 45 to be significantly higher then the age groups 46 to 55 and 66 -plus.

The two economic sustainability factors found significant differences between the age groups above 36. An analysis of variance showed the effect of "cruise lines hire local minorities and women" to be significant, $f(5,257)=5.129, p=.000$. Post hoc analyses using the Scheffe post hoc criterion for significance indicated that the age level of 36 to 45 to be significantly higher then the age groups of 56 and above. The mean for the age group of 36 to 45 was 4.00 , while the mean for the age group of 56 to 65 was 3.82 and the mean for 66-plus was 3.21. An analysis of variance showed the effect of "purchasing policies favor local goods from embarkation ports and ports traveled to throughout a cruise" to be significant, $f(5,257)=3.566, p=.004$. Post hoc analyses using the Scheffe post hoc criterion for significance indicated that the age level of 56 to 65 to be significantly higher than the age group of 66-plus. The mean for the age group of 56 to 65 was 4.03 , while the mean for the age group of 66-plus was 3.49 .

The two social sustainability factors varied on the impact of age. An analysis of variance showed the effect of "cruise lines contribute to the preservation of historical and archaeological sites" to be significant, $f(5,257)=3.781, p=.003$. Post hoc analyses using the Scheffe post hoc criterion for significance indicated that the age level of 56 to 65 to be significantly higher then the age groups 36 to 45 and 66-plus. The mean for the 
age group of 56 to 65 was 4.15 , while the mean for the age group of 36 to 45 was 3.59 and the mean for the age group of 66-plus was 3.64. An analysis of variance showed the effect of "cruise lines avoid the exploitation of local cultures" to be significant, $f(5,257)$ $=3.054, p=.011$. Post hoc analyses using the Scheffe post hoc criterion for significance indicated that the age level of 56 to 65 to be significantly higher than the age group of 26 to 35 . The mean for the age group of 56 to 65 was 4.22 , while the mean for the age group of 26 to 35 was 3.50 .

Hypothesis Four. For hypothesis four, the researcher predicted sustainable practices are more important to woman when choosing a cruise than men. An independent samples t-test was conducted to compare males and females with sustainable factors for choosing a cruise line. The three general sustainability questions noted differences between males and females on importance of sustainability factors. When it came to the idea of choosing one cruise line over another, there was no significant difference in the scores between males and females, $t(264)=-.979, p=.328$. The mean for male respondents was 3.24 and the mean for female respondents was 3.36. For the general sustainability question, "a long-term management plan for sustainability has been developed and implemented," there was a significant difference in the scores between males and females, $t(264)=-5.551, p=.000$. The mean for male respondents was 3.23 and the mean for female respondents was 3.83. For the general sustainability question, "cruise lines observe all applicable regulations in port and in international waters," there was a significant difference in the scores between males and females, $t(264)=-8.947, p$ $=.000$. The mean for male respondents was 3.58 and the mean for female respondents was 4.44. For the general sustainability questions females placed higher importance on 
cruise line sustainability. The means for males and females on general sustainable factors are listed in the table below (see Table 5).

Table 5. Respondent differences in gender for general sustainable factors when choosing a cruise

\begin{tabular}{|c|c|c|}
\hline \multicolumn{3}{|c|}{ Mean of responses for female and male survey respondents } \\
\hline Factor & Female & $\underline{\text { Male }}$ \\
\hline $\begin{array}{l}\text { Observe all applicable } \\
\text { regulations }\end{array}$ & 4.44 & 3.58 \\
\hline $\begin{array}{l}\text { Long-term management } \\
\text { plan for sustainability }\end{array}$ & 3.83 & 3.23 \\
\hline $\begin{array}{l}\text { Choose one cruise line over } \\
\text { another because it is } \\
\text { considered more sustainable }\end{array}$ & 3.36 & 3.24 \\
\hline
\end{tabular}

Male and female responses were then compared in the environmental sustainability factors section on how important the factors influenced the respondent when choosing a cruise line. There were eight environmental sustainability factors for male and female respondents to answer. In five questions there was a significant difference in the scores between males and females. The highest factor for female respondents was 3.86 for the factor of "composting of food waste". The mean for male respondents for this factor was 2.65. The factor of "use of renewable energy sources" received a mean from female respondents of 3.82 and from male respondents the mean was 2.90. The environmental sustainability factor with the no significant difference between males and females was "room card reader for passengers to insert their cruise cards when entering a cabin to turn on electricity." The mean for female respondents was 2.87 and the mean for male respondents was 2.84. Male respondents placed a higher importance than female respondents on two of the eight environmental sustainability factors. The first factor was "access to alternative modes of transportation in ports." The 
mean for male respondents was 3.39 and the mean for female respondents was 3.10. The second factor males placed a higher importance on was "refillable toiletry dispensers in the cabin bathroom." The mean for male respondents was 3.41 and the mean for female respondents was 3.30. This factor also saw no significant difference though between females and males. Additionally there was significant different for green certifications between males and females. The means for males and females on environmental sustainable factors are listed in the table below (see Table 6).

Table 6. Respondent differences in gender for environmental sustainable factors when choosing a cruise

\begin{tabular}{|c|c|c|}
\hline \multicolumn{3}{|c|}{ Mean of responses for female and male survey respondents } \\
\hline Factor & Female & Male \\
\hline$\overline{\text { Composting of food waste }}$ & 3.86 & $\overline{2.65}$ \\
\hline $\begin{array}{l}\text { Use of renewable energy } \\
\text { sources }\end{array}$ & 3.82 & 2.90 \\
\hline $\begin{array}{l}\text { Refillable toiletry } \\
\text { dispensers in the cabin } \\
\text { bathroom }\end{array}$ & 3.30 & 3.41 \\
\hline $\begin{array}{l}\text { Use of renewable materials } \\
\text { and finishes }\end{array}$ & 3.17 & 2.93 \\
\hline $\begin{array}{l}\text { Green and sustainable } \\
\text { certifications }\end{array}$ & 3.10 & 2.91 \\
\hline $\begin{array}{l}\text { Access to alternative modes } \\
\text { of transportation in ports }\end{array}$ & 3.10 & 3.39 \\
\hline $\begin{array}{l}\text { Room card reader for } \\
\text { passengers to insert their } \\
\text { cruise cards when entering a } \\
\text { cabin }\end{array}$ & 2.87 & 2.84 \\
\hline
\end{tabular}

The researcher then compared male and female responses for the economic sustainability factors. There were five economic sustainability factors for male and female respondents to answer. In all five questions there was a significant difference in the scores between males and females. Female respondents placed a higher importance 
than male respondents on all five economic sustainability factors. The factor females placed the highest importance on was "crew are paid a living wage," $t(264)=-9.295, p=$ .000 . The mean for female respondents was 4.11 and the mean for male respondents was 3.21. For the factors on employment, male respondents placed the lowest importance on both factors. The factor on "cruise lines give local residents the opportunity to gain employment," received a mean of 3.17 from males and a mean of 3.97 from females, $t$ $(264)=-7.533, p=.000$. The factor on "cruise lines hire local minorities and women," received a mean of 3.12 from males and a mean of 3.93 from females, $t(264)=-6.692, p$ $=.016$. The factor females placed the lowest importance on was "cruise lines support local businesses selling sustainable products that represent a destination's culture, history, and nature," $t(264)=-2.433, p=.000$. The mean for female respondents was 3.85 and the mean for male respondents was 3.57. The means for males and females on economic sustainable factors are listed in the table below (see Table 7).

Table 7. Respondent differences in gender for economic sustainable factors when choosing a cruise

Mean of responses for female and male survey respondents

\begin{tabular}{lcc}
$\begin{array}{l}\text { Crews are paid a living } \\
\text { wage }\end{array}$ & $\begin{array}{c}\text { Female } \\
4.11\end{array}$ & $\frac{\text { Male }}{3.21}$ \\
$\begin{array}{l}\text { Cruise lines give local } \\
\text { residents the opportunity to } \\
\text { gain employment }\end{array}$ & 3.97 & 3.17 \\
$\begin{array}{l}\text { Cruise lines hire local } \\
\text { minorities and women }\end{array}$ & 3.93 & 3.12 \\
$\begin{array}{l}\text { Purchasing policies favor } \\
\text { local goods }\end{array}$ & 3.92 & 3.55 \\
$\begin{array}{l}\text { Cruise lines support local } \\
\text { businesses selling } \\
\text { sustainable products }\end{array}$ & 3.85 & 3.57 \\
\hline
\end{tabular}


The last section the researcher compared for male and female responses on sustainability was for the social sustainability factors. There were seven social sustainability factors for male and female respondents to answer. In four of the seven questions there was a significant difference in the scores between males and females. Female respondents placed a higher importance than male respondents on all seven social sustainability factors. The highest mean for both females and males was for the factor "all applicable health and safety measures are taken to protect passengers, crew, and local communities." This factor though did not have any significant difference between males and females. The mean for female respondents was 4.55 and the mean for male respondents was 4.43 . The second highest mean in the social sustainability category was for the factor "international legal protection is provided to crew." The mean for female respondents was 4.31 and the mean for male respondents was 3.77 .

The lowest social mean for females was for the factor "cruise lines support communities traveled to with projects supporting development of communities and infrastructure." This factor saw no significant difference between male and female respondents. The mean for female respondents was 3.91 and the mean for male respondents was 3.71. The lowest mean for males was for the factor "cruise lines contribute to the preservation of historical archeological sites." The mean for male respondents was 3.56 and the mean for female respondents was 4.00. Additionally, there was no significant difference in the results for "activities of cruise ships should not compromise the basic services in port. The means for males and females on social sustainable factors are listed in the table below (see Table 8). 
Table 8. Respondent differences in gender for social sustainable factors when choosing a cruise

\begin{tabular}{|c|c|c|}
\hline \multicolumn{3}{|c|}{ Mean of responses for female and male survey respondents } \\
\hline & Female & Male \\
\hline $\begin{array}{l}\text { All applicable health and } \\
\text { safety measures are taken to } \\
\text { protect passengers, crew, } \\
\text { and local communities }\end{array}$ & 4.55 & $\overline{4.43}$ \\
\hline $\begin{array}{l}\text { International legal } \\
\text { protection is provided to } \\
\text { crew }\end{array}$ & 4.31 & 3.77 \\
\hline $\begin{array}{l}\text { Cruise lines avoid the } \\
\text { exploitation of local } \\
\text { cultures }\end{array}$ & 4.17 & 3.76 \\
\hline $\begin{array}{l}\text { Information provided to } \\
\text { passengers about local } \\
\text { cultures }\end{array}$ & 4.16 & 3.91 \\
\hline $\begin{array}{l}\text { Activities of cruise ships } \\
\text { should not compromise the } \\
\text { basic services in port }\end{array}$ & 4.04 & 3.97 \\
\hline $\begin{array}{l}\text { Cruise lines contribute to } \\
\text { the preservation of } \\
\text { historical archeological sites }\end{array}$ & 4.00 & 3.56 \\
\hline $\begin{array}{l}\text { Cruise lines support } \\
\text { communities traveled to } \\
\text { with projects supporting } \\
\text { development of } \\
\text { communities and } \\
\text { infrastructure }\end{array}$ & 3.91 & 3.71 \\
\hline
\end{tabular}

\section{Summary}

This study sought to identify how consumers view sustainability in the cruise industry. After the survey period was completed, the information was coded and then analyzed. While the information was analyzed from the surveys, patterns began to emerge. Additionally the researcher noted a difference in specific demographics on sustainable views, particularly the demographic of gender. Overall female respondents 
placed a higher importance on most sustainable cruise factors compared to male respondents. Additionally, the researcher noted differences on sustainability between past cruisers and respondents who had not cruised. 


\section{CHAPTER V: DISCUSSION}

The goal of this study was to determine how consumers perceive sustainability in the cruise industry. The researcher sought to understand if any sustainable factors in the cruise industry were important to consumers and whether consumers felt the industry was sustainable. The researcher believed it was important to understand cruise line sustainability and consumer perceptions due to lack of previous research on this topic. As stated before, consumer perceptions on sustainability in the travel industry has been previously studied, but this research did not examine the cruise industry. The following chapter discusses the findings of this study, recommendations, and future research suggestions.

\section{Research Question One}

Research question one sought to answer, what factors influence a consumer to book a cruise? Just as it is important to understand how consumers perceive sustainability in the cruise industry, it is equally important to understand the factors that influence consumers to book a cruise. Foster et al. (2000) argued hotels and tourism businesses are under pressure to become more sustainable and environmentally friendly. From the survey results, the researcher found consumers place a higher preference on other factors for choosing a cruise line over environmental friendliness. Consumer participants in the study placed the highest preference on the factor of itinerary. The destination of a cruise was ultimately more important than environmental friendliness of a cruise line, which the researcher predicted in hypothesis two. The researcher felt this related to the information

presented by Kim et al. (2012) regarding the hotel industry. Kim et al. argued the purpose 
for needing a hotel did not influence a consumer's choice for choosing to stay at an ecofriendly hotel, which can also relate to the cruise industry. The potential environmental friendliness of a cruise line may not impact a consumer's decision on choosing the line because the purpose of selecting the cruise is more influenced by itinerary. Itinerary is more likely to have a purpose when choosing a cruise over cruise line environmentalism. In addition, cost of cruise received the second highest preference. The researcher predicted in hypothesis one that cost of cruise would be more important than environmental friendliness of a cruise line, which the hypothesis was proven correct by survey respondents. This followed a similar pattern that was argued by Millar and Baloglu (2011). Millar and Baloglu noted not all consumers' viewed green hotels favorably due to the factor of expense. The researcher noted cost was a more important factor to consumers than environmental friendliness. According to Han et al. (2010) and Manaktola and Jauhari (2007), consumers in the hotel industry had expressed a higher preference for hotels that showed concern for the environment. Respondents from the research study placed a higher importance on price and destination when making cruise decisions. These results differed from the hotel industry results from Han et al. (2010) and Manaktola and Jauhari (2007) who argued some hotel consumers placed a higher importance on environmental friendliness. Even though environmental degradation was a concern for cruise consumers, price and itinerary received a higher significance from cruise consumers. Overall both cost of cruise and itinerary was more important to consumers than the environmental friendliness of a cruise line.

The researcher did not expect cuisine to receive such high importance from consumers for factors in booking a cruise. Cuisine received the third highest level of 
importance from consumers. Shopping and water activities in port received the lowest levels of importance for consumers. The researcher felt this was interesting since the cruise industry does place a high level of importance on shopping in ports and on selling shore excursions to passengers. The factor of accessibility of accommodations for disabilities received the lowest importance for consumers, which the researcher felt was an interesting response. The researcher felt this number could change depending on who was taking the survey. If survey respondents had disabilities or traveled with someone who is disabled, more likely the importance level would increase.

\section{Research Question Two}

The objective of research question two was to answer, what sustainable factors are important to consumers when choosing a future cruise? This question was important to examine, in order to determine if any sustainable factors are important to consumers in the cruise industry. Previous research has found environmental concerns from consumers have impacted their decision-making process and some consumer purchasing behaviors (Gilg et al., 2005; Hackett, 1993; Kilbourne \& Beckmann, 1998; Zimmer et al., 1994). Before examining cruise sustainable factors consumers were asked a series of questions on sustainable travel behaviors. The researcher found consumers placed higher importance on economic and social behaviors over environmental behaviors. The factor respondents identified with most was eating at locally owned restaurants instead of chain restaurants. Secondly consumers identified with purchasing local products as a factor they identified with. The researcher felt this was an interesting choice for consumers to identify with since these choices contributed to communities financially. The researcher 
was surprised that respondents placed a lower agreement level on environmental behaviors.

Consumers were then asked to place their level of importance on sustainable factors for choosing a cruise line. Previous research by Anderson and Cunningham (1972) and Berkowitz and Lutterman (1968) noted socially conscious individuals are more likely to place a higher importance on sustainable factors. Respondents once again placed a higher importance on social factors over environmental factors. The factors that received the highest importance focused on following health and safety measures, governmental regulations, and international legal protection for crew. Consumers also felt it was important to receive information about the port visited and to understand the customs and cultures of a destination. This shows that consumers want to have information provided to them about customs and culture of a port, which the researcher feels is due to wanting to understand a destination and becoming more culturally aware. The researcher thought it was interesting that consumers once again placed the highest importance on social factors, particularly those related to laws and regulations. The researcher feels consumers want the cruise industry to not cut corners when it comes to laws and regulations because these directly impact the consumer.

When it came to the environmental pillar of sustainability, consumers placed less importance on these factors for choosing the cruise line. The results from the environmental pillar of sustainability are different from other research studies since consumers participating in the survey placed less significance on environmentalism. Foster et al. (2000) noted consumers have placed pressure on the hotel industry and tourism businesses to become more sustainable. This pressure had led hotel operators to 
focus on making hotel operations environmentally friendly (Han et al., 2009). The researcher noted social and economic sustainability were more important than environmental sustainability.

The one environmental factor consumers disagreed with would directly impact their cabin experience. The factor was a room card reader for guests to insert their cabin card into, which would then control the cabin electricity. This factor is to help conserve electricity, but guests may not agree with it since this will turn the electricity off when they leave the cabin and take their key card with them. Consumers may consider this to be an inconvenience, which could lead to why this factor had a mean of importance of 2.85. Consumers also placed little importance on having alternative modes of transportation in ports. This surprised the researcher since alternative modes of transportation could enhance a visit in a port and provide more possibilities of transportation. The researcher felt consumers may not feel this is important because they might want to have quick transportation and could feel alternative methods are slower. The other factors of environmental sustainability primarily focused on factors consumers will not directly feel, but will help to protect the environment. The researcher believes consumers placed less importance on these factors due to not directly feeling the results when protecting the environment. Consumers would place a higher level of importance on a factor if it were likely to have a positive affect on their vacation. If the factor had the potential to create a negative effect for a consumer's vacation, the consumer was more likely to place a lower level of importance on the factor. 


\section{Research Question Three}

Research question three sought to answer, how do consumers perceive environmental, social, and economic impacts of sustainability in the cruise industry? This research question was created because there was a lack of available previous research regarding the cruise industry. Previous research has focused primarily on the hotel industry. Han et al. (2010) and Manaktola and Jauhari (2007) noted the hotel industry has experienced an increase of consumer preference for hotels that show concern for the environment. The purpose of research question three was to examine how consumers viewed the industry and what sustainable factors influenced their choice in selecting a cruise line.

Vora (2007) argued that American travelers have expressed their concerns over the impact of travel on the environment. This is important to note since the researcher presumes most survey respondents will be predominately located in the United States due to posting on cruise message boards and Facebook pages that seemed to have a larger presence of Americans participating. From the survey results the researcher noted over half of consumers felt the cruise industry was sustainable and this percentage increased for consumers who had a more extensive cruise history. The researcher felt this related to the information presented by Kim and Han (2010). Kim and Han argued that consumers who are concerned about the environment are more likely to stay in an environmentally friendly hotel. This relates to the cruise industry since consumers who are more likely to be concerned will most likely view the industry as not sustainable. The researcher feels if a consumer is more likely to cruise, then this individual is more likely to feel the industry is sustainable. 
Half of respondents who had not cruised had no opinion on cruise line sustainability, which is different from respondents who had cruised. The researcher felt respondents who had cruised were more likely to feel the industry was sustainable, since this was a mode of travel the respondents had partaken in more than once and most likely enjoyed. When it came to respondents scoring cruise lines on sustainability, the cruise lines that received the highest scores on sustainability were Celebrity Cruises and Princess Cruises. Both Celebrity Cruises and Princess Cruises had also received the highest preference for cruising by respondents as well. Cruise lines that received lower preference for cruising then received lower scores on sustainability from respondents. The researcher found this interesting since it seemed as though respondents more favorably viewed a cruise line for being sustainable if the cruise line was their preferred line to sail.

\section{Research Question Four}

The purpose of research question four was to answer, are there differences within demographics on consumer perceptions of cruise line sustainability? Just as it is important to understand how consumers view cruise line sustainability, it is equally important to examine how demographics may or may not influence their perceptions. Tyrväinen et al. (2014) argued the background of consumers could influence their views and choices. Consumers can perceive sustainable practices differently because of their culture, personal backgrounds, and motivations. The researcher felt it was important to examine differences within demographics since an individual's demographic could influence his or her views. The researcher conducted SPSS testing on all the demographic 
variables. Demographics have previously shown an influence on consumer behavior towards environmental consciousness in a previous study by Larchoe et al. (2001). For the demographic variables of ethnicity origin, community living choice, and highest education level achieved, the researcher found no significant differences between these demographics. The researcher feels for the demographic of ethnicity origin, there were no significant differences because a majority of survey participants selected the ethnicity of Caucasian. This left the demographic variable of ethnicity to be one-sided, which most likely impacted any potential of significant differences in the results. For the demographic of community living choice, the factor of rural received a very low response since most survey respondents selected either urban or suburban for the survey. The demographic of highest education level achieved was more evenly spread out between consumers. The researcher was surprised there was no significant difference for this factor when there was a significant difference for the factor of income.

The factor of income had a significant effect on some of the sustainable factors that were important to consumers when choosing a cruise line. In a study conducted by Han et al. (2011), income was found to not create any notable differences when consumers chose a green hotel. The study by Kim et al. (2012) was found to have similar results with the data collected in this study. Kim et al. (2012) found consumers who made a higher income were more likely to choose a green hotel. The researcher found respondents who earned a higher income were more likely to favor the sustainable factors. Consumers with higher income levels were concerned with long term management plans for sustainability and cruise lines observing applicable governmental regulations. The factor of alternative transportation methods available in ports saw a 
significant difference between income levels. The income level of $\$ 150,000$ or more placed a low level of importance on this factor, while the income levels between $\$ 40,000$ to $\$ 149,999$ placed a high level importance on this factor. The higher income level of $\$ 150,000$ or more generally placed a higher significance on sustainability compared to lower income levels, which the researcher thought was interesting for the results on alternative methods of transportation. The researcher was surprised the highest income level did not place a significant importance on this factor when other income levels did. The factor of composting food waste had the opposite results from alternative transportation methods. The income level of $\$ 40,000$ to $\$ 59,999$ did not place an importance on composting food waste, but the income levels of $\$ 100,000$ or more did place an importance on this factor. Furthermore the income levels of $\$ 100,000$ or more placed a higher significance on cruise line sustainable factors than the income levels between $\$ 40,000$ to $\$ 59,999$. The researcher felt the differences in income were interesting since consumers with higher incomes placed greater importance on sustainable factors than consumers with lower incomes.

For hypothesis three the researcher predicted sustainable practices would be more important to younger cruisers than older cruises. The researcher based the hypothesis off the idea that younger individuals are more likely to be socially conscious due to early studies on demographics by Anderson and Cunningham (1972), and Berkowitz and Lutterman (1968). Recent studies also found age to have an important role in consumer environmental perceptions and behavior towards the environment (Torgler et al., 2008). The factor of age in this study only influenced a difference in specific sustainable factors. There was no significant difference for 17 sustainable factors in the survey between 
young and older cruisers. This was similar to the results presented by Han et al. (2011) who found age did not play a significant role for consumers in choosing green hotels in their study. The researcher was surprised by the results from the survey since only six sustainable factors had a significant difference for age. The researcher believes the various differences can be due to the ideas argued by Vlosky and Vlosky (1999). Vlosky and Vlosky argued an individual can be influenced by the generation he or she was born into. Generational difference can affect an individual's viewpoint and outlook on sustainability. Particularly an individual is influenced by life experiences he or she may face from economy, political experiences, and social life (Vlosky \& Vlosky, 1999). The researcher believes the argument presented by Vlosky and Vlosky may account for the six significant differences based on age for the sustainable factors.

There was significant difference between age for two environmental factors, two economic factors, and two social factors. Older cruisers in the age group of 56 to 65 placed a higher importance on green and sustainable certification compared to middle age cruisers in the age group of 46 to 55 . The researcher was surprised though that older cruisers placed a higher importance on certifications. Evanschitzky \& Wunderlich (2006) argued older individuals are more likely to go to information that already exists from sources he or she relies on. Even though older respondents may not be familiar with the green and sustainable certifications, these respondents could be used to relying on other certifications. This may be why older respondents placed a significant importance on certifications. On the other hand, younger cruisers in the age group of 26 to 45 placed a significant importance on alternative modes of transportation compared to cruisers who were 46 and older. The researcher was not surprised that younger consumers placed a 
higher importance on alternative modes of transportation since younger consumers are generally considered to be more active. This also can be related to the information presented by Evanschitzky \& Wunderlich (2006) who argued younger individuals are focused on new ways to search for information and alternative resources for information. These consumers do not want to search for information the same way and this also changes their buying habits. Younger consumers are considered more willing to try new products (Im et al., 2003), which could influence why alternative modes of transportation was a more significant factor since this is different from traditional transportation methods.

Two economic factors also did not see young cruisers placing a significant difference between other age groups. Middle-age consumers placed a high importance on hiring practices compared to cruisers over the age of 56 and above. The researcher believes this may be due to the fact this consumer group is more likely to be in the workforce compared to older consumers. The researcher was surprised this factor did have a significant importance for younger consumers. The economic factor of purchasing policies saw a different outcome from the factor of hiring practices. The age level of 56 to 65 placed a significant importance on this factor while it was not as important to consumers under the age of 55 or over the age of 66 . The two social sustainable factors also had similar results. The factor of preservation of historical and archeological sites was more significant to consumers between the ages of 56 to 65 than consumers 36 to 45 and over the age of 66 . The factor of exploitation of local cultures was also significant for consumers between the ages of 56 to 65 but was not significant to consumers 26 to 35 . 
The researcher was surprised by the overall results for the six factors where there was a significant difference. Ultimately middle-aged cruisers placed a higher importance level on the six sustainable factors than younger and older cruisers. The researcher felt this was interesting since younger cruisers only placed a higher importance level on alternative modes of transportation. The other 17 factors had no significant difference between age groups, which showed in this survey age only played a role in specific factors not entire pillars of sustainability. Overall the researcher was surprised by the results since previous studies have found age to have a significant role in consumer preferences for sustainability (Im et al., 2003; Evanschitzky \& Wunderlich, 2006). Previous evidence showed younger individuals are more likely to have a higher level of knowledge regarding the environment (Arcury et al., 1987; Grunert \& Kristensen, 1992). Younger consumers have demonstrated in the past to be more concerned with the environment than older consumers (Howell \& Kaska, 1992). The researcher believes with this survey differences in age may be due to generational differences. The researcher did not expect the results regarding age differences in this study with middle-aged consumers placing a higher importance on sustainable factors than younger and older cruisers.

In hypothesis four the researcher predicted sustainable practices would be more important to women when choosing a cruise than men. Previous research studies noted female consumers were likely to be more socially conscious individuals than males (Anderson \& Cunningham, 1972; Berkowitz \& Lutterman, 1968). Zelezny et al. (2000) argued female consumers have shown more concern for the environment as well. Past studies that focused on female consumers showing more concern for the environment and sustainability also proved correct in this research study about the cruise industry. Female 
respondents placed a higher importance on sustainability and additionally stated it was important for a cruise line to have a long-term management plan for sustainability. Female responses in this study were similar to those surveyed in green hotel studies. Han et al. (2011) and Kim et al. (2012) noted in their research studies females are more likely to choose a green hotel over males. The results were similar from their studies to the results in this research study.

Environmental sustainability also predominately saw female respondents placing a higher significance on sustainability. Only two factors did males place as more important than females. The factor of alternative modes of transportation and refillable toiletry dispensers were more significant to male consumers. The researcher felt the second factor of refillable toiletry dispensers was more likely to be significant to men since women may be more likely to bring their own bath products on vacation than men. The researcher was not surprised that male respondents placed a higher importance on alternative methods of transportation. Men typically seem to be targeted by advertisements for various transportations methods, which does lead the researcher to believe male consumers are more likely to be concerned about transportation. The significant differences in these two factors can relate to the information presented by Han and Ryu (2006). Han and Ryu argued there are differences in consumption patterns between consumers, particularly males and females. Also noted by Han and Ryu is different decision-making processes for male and female consumers. The argument presented by Han and Ryu can help to explain the only two factors male consumers placed a higher significance on. Both factors can be considered to lean towards male 
consumption patterns, which the researcher believes is why these two factors received a significant importance from male consumers.

When it came to the economic sustainability factors, women placed a higher importance on all of the factors compared to men. For the social sustainability factors, there was a significant difference in results for four of the seven factors. Women still placed a higher importance on all seven factors though. Females have shown a difference in their social role compared to males. This is most likely due to the fact women generally have more roles and duties when raising children and running households. Eagly (1987) noted females are more likely to be concerned about the welfare of other individuals. It has also been noted that females are more likely to volunteer than males (Bekkers, 2005). The researcher feels women typically take on more family responsibilities than men. Female consumers have shown in previous studies that they are more concerned overall about social and economic problems (Eagly, 1987; Bekkers, 2005). Female consumers have shown a higher preference for communication and the attainment of information (Lehto et al. 2001). This is most likely to influence how female respondent view sustainability for all three pillars and why women place a higher importance on all the factors for sustainability.

\section{Study Implications}

The findings of this study provide a variety of implications into consumer perceptions of sustainability in the cruise industry and the factors of importance for consumers to choose a cruise. The research will help the cruise industry and sustainable travel organizations to understand the insights of cruise consumers in regards to 
sustainability. This can further help the cruise industry to work on increasing sustainable awareness across cruise line fleets and in ports traveled to. The findings are also beneficial for bringing awareness to consumers about issues of sustainability in the cruise industry.

\section{Recommendations}

The data from the present study shows there are differences on how consumers perceive sustainability in the cruise industry and the factors that are important for these consumers. As stated in this chapter, demographics and cruise travel history have demonstrated an impact on consumers' views on sustainability. Some of these differences in view points from consumers on sustainability are still unexplained, even with this research and findings. Does age and gender truly affect a consumer's viewpoint on sustainability? Does any other demographics influence a consumers' point of view on sustainability? Will travel history influence or affect a consumer's perspective on sustainability in the travel industry? Even with the research conducted in this study, there is still ambiguity in the influence on consumer perceptions. In answering these questions, the researcher can better understand consumer perspectives and how to address these issues through future research. This will unequivocally advance the body of literature to new levels and provide additional information and tools to the cruise industry and sustainable tourism organizations that seek to improve sustainability in the travel and cruise industry. 


\section{Suggestions for Further Research}

This study demonstrated the value of quantitative methods in examining how various consumers with different travel backgrounds perceive the cruise industry on sustainability and the factors of importance for choosing a cruise. Further research should expand on the information gained in this study by conducting both qualitative and quantitative studies. The researcher would recommend a qualitative study be conducted to compare how individuals in narrower demographics and travel backgrounds feel about the sustainability of the cruise industry. With a study solely focused on the interview with consumers, this can help to create a better understanding regarding specific concerns from consumers about the cruise industry and if there are any additional differences in demographics.

In addition, the researcher recommends additional quantitative studies to be conducted by reaching out to consumers in different ways other than cruise message boards and social media. This could help to determine if consumers who may not frequent cruise message boards or social media have different perspectives about cruise line sustainability. The research from future studies could then be compared to the research findings in this study, to see if there are similar themes that emerge between consumers. Furthermore, new awareness and time between studies could influence consumer views on sustainability. As there is still more information to be discovered about the impact of the cruise industry on the environment and local communities, it is important for further research to gain a better understanding of the overall impact of the cruise industry on sustainability and how consumers feel about the impacts from the cruise industry. 


\section{REFERENCES}

Anderson, T., \& Cunningham, W. H. (1972). The socially conscious consumer. Journal of Marketing, 36(7), 341-347.

Angelevska-Najdeska, K., \& Rakicevik, G. (2012). Planning of sustainable tourism development. Procedia - Social and Behavioral Sciences, 44(0), 210-220.

Anglen, R. (2012, June 9). Law withholds cruise-safety information. The Republic. Retrieved from http://www.azcentral.com/news/politics/articles/2012/06/09/20120609cruise-linecrime-call12.html

Arcury, T. A., Scollay, S. J., \& Johnson, T. P. (1987). Sex differences in environmental concern and knowledge: The case of acid rain. Sex Roles, 16, 463-472.

Banerjee, B., \& McKeage, K. (1994). How green is my value: Exploring the relationship between environmentalism and materialism. Advances in Consumer Research, 21, 147-152.

Bekkers, R. (2005). Participation in voluntary associations: Relations with resources, personality, and political values. Political Psychology, 26(3), 439-454.

Bell, D. V., Odin, N., Austin, A., Hayhow, S., Jones, A., Strong, A., \& Torres, E. (1984). The impact of anglers on wildlife and site amenity. Department of Applied Biology, UWIST.

Bell, T. (2007, September 28). Experts: Mega-berth needed for cruise ships. Portland Press Herald.

Bergantino, A., \& Marlow, P. (1998). Factors influencing the choice of flag: Empirical evidence. Maritime Policy \& Management, 25(2), 157-174.

Berkowitz, L., \& Lutterman, K. G. (1968). The traditional socially responsible personality. Public Opinion Quarterly, 32, 169-185.

Bonilla-Priego, M. J., Font, X., \& Pacheco-Olivares, M. D. R. (2014). Corporate sustainability reporting index and baseline data for the cruise industry. Tourism Management, 44(0), 149-160.

Branchik, B. J. (2011). Ship ahoy: A history of maritime passenger industry marketing. Conference of Historical Analysis and Research in Marketing. Retrieved from http://faculty.quinnipiac.edu/CHARM/CHARM proceedings/CHARM article archive pdf format/Volume 15 2011/Ship Ahoy.pdf 
Brida, J. G., \& Aguirre, S. Z. (2008). The impacts of the cruise industry on tourism destinations. Sustainable tourism as a factor of local development.

Brown, K. W., \& Kasser, T. (2005). Are psychological and ecological well-being compatible? The role of values, mindfulness, and lifestyle. Social Indicators Research, 74, 349-368.

Burak S., Doğan, E., \& Gazioğlu, C. (2004). Impact of urbanization and tourism on costal environment. Ocean \& Coastal management, 47, 515-527.

Butler, D. A. (2004). The age of Cunard: A transatlantic history 1839-2003. Annapolis: Lighthouse Press.

Butler, R. W. (1999). Sustainable tourism: A state-of-the-art review. Tourism Geographies, 1, 7-25.

Camarda, D., \& Grassini, L. (2003). Environmental impacts of tourism. International Centre for Advanced Mediterranean Agronomic Studies.

Campbell, J. (2007). Why would corporations behave in socially responsible ways? An institutional theory of corporate social responsibility. Academy of Management Review, 32, 946-967.

Carnival Corporation. (n.d.). Corporate governance. Retrieved from http://phx.corporateir.net/phoenix.zhtml?c=140690\&p=irol-govmanage

Castellani, V., \& Sala, S. (2010). Sustainable performance index for tourism policy development. Tourism Management, 31(6), 871-880.

CERES. (n.d.). CERES' green hotel initiative: Best practice survey. Retrieved February 10,2014 , from http://www.greenbiz.com/sites/default/files/document/O16F21793.pdf

Clancy, M. (2008). Cruisin' to exclusion: Commodity chains, the cruise industry, and development in the Caribbean. Globalizations, 5(3), 405-418.

Commercial Passenger Vessel Environmental Compliance Program. (2013, December 16). Department of Environmental Conservation. Retrieved June 9, 2014, from http://dec.alaska.gov/water/cruise_ships/Law_and_Regs/18_AAC_69.pdf

Commission for Environmental Cooperation. (2000). Promoting sustainable tourism in North America's natural areas: The steps forward. Commission for Environmental Cooperation. 
Cruise Critic. (n.d., a). About us. Retrieved March 28, 2014, from http://www.cruisecritic.com/aboutus/

Cruise Critic. (n.d., b). Cruise critic message board forums. Retrieved March 28, 2014, from http://boards.cruisecritic.com

Cruise Lines International Association. (2013). 2013 North America cruise industry update. Cruise Lines International Association, Retrieved from http://www.cruising.org/sites/default/files/pressroom/CruiseIndustryUpdate2013F INAL.pdf

Cruise Lines International Association. (2014). The state of the cruise industry in 2014: Global growth in passenger numbers and product offerings [Press released]. Retrieved from http://www.cruising.org/vacation/news/press_releases/2014/01/state-cruiseindustry-2014-global-growth-passenger-numbers-and-product-o

Cruise Lines International Association. (n.d., a). About CLIA. Cruise Lines International Association, Retrieved April 14, 2014, from http://www.cruising.org/regulatory/issues-facts

Cruise Lines International Association. (n.d., b). Issues and facts. Cruise Lines International Association, Retrieved April 14, 2014, from http://www.cruising.org/regulatory/issues-facts

Cruisemates. (n.d.). About. Retrieved May 1, 2014, from http://www.cruisemates.com/articles/about/

Cunard to register ships in Bermuda. (2011, October 20). The Telegraph. Retrieved from http://www.telegraph.co.uk/travel/cruises/8838472/Cunard-to-register-ships-inBermuda.html

Davenport, J., \& Davenport, J. (2006). The impact of tourism and personal leisure transport on coastal environments: A review. Estuarine, Coastal and Shelf Science, 67, 280-292.

Day, J. (2012). The challenges of sustainable tourism. Journal of Tourism Research \& Hospitality. Retrieved from http://www.scitechnol.com/2324-8807/2324-8807-1e108.pdf

Diamantopoulos, A., Schlegelmilch, B. B., Sinkovics, R. R., \& Bohlen, G. M. (2003). Can socio-demographics still play a role in profiling green consumers? A review of the evidence and an empirical investigation. Journal of Business Research, 56, $465-480$. 
Diaz-Benevides, D. (2001). Seminar on tourism policy and economic growth. OECD, Berlin, 6-7 March 2001.

Dowling, R. K. (2006). Cruise ship tourism. Oxfordshire: CAB International.

Dwyer, L., \& Forsyth, P. (1998). Economic significance of cruise tourism. Annals of Tourism Research, 25(2), 393-415.

Eagly, A. (1987). Sex differences in social behavior: A social role interpretation. Hillsdale: L. Erlbaum Associates.

Edwards, A. (2005). The sustainability revolution: Portrait of a paradigm shift. Gabriola Island: New Society Publishers.

Environmental Protection Agency. (2008). Cruise ship discharge assessment report (EPA 842-R-07-005).

Environmental Protection Agency. (2012). Guidelines for water reuse (EPA 600-R-12618). Retrieved from http://nepis.epa.gov/Adobe/PDF/P100FS7K.pdf

Environmental Protection Agency. (2012). Title XIV - Certain Alaskan cruise ships operations. Retrieved from http://water.epa.gov/polwaste/vwd/titlexiv.cfm

Environmental Protection Agency. (n.d., a). Sustainability basic information. Retrieved April 2, 2014, from http://www.epa.gov/sustainability/basicinfo.htm

Environmental Protection Agency. (n.d., b). Sustainability primer. Retrieved April 2, 2014, from http://www.epa.gov/ncer/rfa/forms/sustainability_primer_v7.pdf

Environmental Protection Agency. (n.d., c). Water recycling and reuse: The environmental benefits. Retrieved May 15, 2014, from http://www.epa.gov/region9/water/recycling/brochure.pdf

Erftemeijer, P. L. A., Riegl, B., Hoeksema, B. W., \& Todd, P. A. (2012). Environmental impacts of dredging and other sediment disturbances on corals: A review. Marine Pollution Bulletin, 64(9), 1737-1765.

Espinal, L. (2005). Terminales de Crucero en Centroamérica y El Caribe. Retrieved from http://www.oas.org/cip/esp/areastecnicas/1230terminalesdecruceroencentroamericayelcaribe-sra.lludelisespinal.doc

European Commission. (2006). A renewed EU tourism policy: Towards a stronger partnership for European tourism. Communication from the commission. 
Eurostat. (2006). Methodological work on measuring the sustainable development of tourism. European Commission. Retrieved from Office for Official Publicans for the European Communities website:

http://epp.eurostat.ec.europa.eu/portal/page/portal/tourism/documents/KS-DE-06001-EN.pdf

Eurostat. (2009). Medstat II: Water and tourism pilot study. Eurostat, European Commission. Retrieved March 2, 2014, from http://epp.eurostat.ec.europa.eu/portal/page/portal/product_details/publication?p_ product_code=KS-78-09-699

Evanschitzky, H., \& Wunderlich, M. (2006). An examination of moderator effects: The four stage loyalty model. Journal of Service Research, 8(4), 330-345.

Florida Seaport Transportation and Economic Development Council. (2014). The fiveyear Florida seaport mission plan. Retrieved from http://flaports.org/wpcontent/uploads/FL-PORT-COUNCIL-BOOK-652014sm.pdf

Foster, S. T., Sampson, S. E., \& Dunn, S. C. (2000). The impact of customer contact on customer contact on environmental initiatives for service firms. International Journal of Operations \& Production Management. 20(20), 187-203.

Friends of the Earth. (2013). 2013 cruise report card. Retrieved February 27, 2014, from http://www.foe.org/cruise-report-card

Frueh, S. (1988). Report to WWF on tourism to protected areas. Ecotourism: The Potentials and Pitfalls, 1. Washington, DC: World Wildlife Fund

Gelinas, M., Bokuniewicz, H., Rapaglia, J., \& Lwiza, K. M. M. (2013). Sediment resuspension by ship wakes in the Venice Lagoon. Journal of Coastal Research, 29(1), 8-17.

General Assembly of the United Nations. (n.d.). Sustainable development. Retrieved from http://www.un.org/en/ga/president/65/issues/sustdev.shtml

George, R. (2011, April 24). Flying the flag, fleeing the state. The New York Times. Retrieved from http://www.nytimes.com/2011/04/25/opinion/25george.html?_r=2\&ref=opinion\&

Gibson, W. E. (2013, September 22). Port expansions may bring jobs. Orlando Sentinel. Retrieved from http://articles.orlandosentinel.com/2013-09-22/news/fl-ports-jobscongress-20130922-5_1_port-canaveral-port-director-steven-cernak-busiestcruise-port 
Gilg, A., Barr, S., \& Ford, N. (2005). Green consumption or sustainable lifestyles? Identifying the sustainable consumer. Futures, 37, 481-504.

Global Sustainable Tourism Council. (n.d., a). Global sustainable tourism criteria for hotels and tour operators. Retrieved February 7, 2014, from http://www.gstcouncil.org/sustainable-tourism-gstc-criteria/criteria-for-hotelsand-tour-operators.html

Global Sustainable Tourism Council. (n.d., b). International standards. Retrieved March 30, 2014, from http://www.gstcouncil.org/gstc-objectives/gstc-internationalstandards.html

Good, J. (2007). Shop 'til we drop? Television, materialism and attitudes about the natural environment. Mass Communications \& Society, 10(3), 365-383.

Gössling, S., Peeters, P., Hall, C. M., Ceron, J. P., Dubois, G., Lehmann, La V., \& Scott, D. (2012). Tourism and water use: Supply, demand, and security. An international review. Tourism Management, 33, 1-15.

Green Globe. (n.d., a). Green globe certification standard. Retrieved February 7, 2014, from http://greenglobe.com/green-globe-certification-standard/

Green Globe. (n.d., b). Green globe travel. Retrieved February 7, 2014, from http://greenglobe.travel/

Gregory, W. R. (2012). Flags of convenience: The development of open registries in the global maritime business and implications for modern seafarers. (Order No. 1530402, Georgetown University). ProQuest Dissertations and Theses, 119.

Grunert, S. C., \& Kristensen, K. (1992). The green consumer: Some Danish evidence. Annual Conference of the European Marketing Academy, Marketing for Europe Marketing for the Future, 1, 525-540.

Gulliksen, V. (2008). The cruise industry. Society, 45(4), 342-344.

Hackett, P. M. W. (1993). Consumer's environmental concern values: understanding the structure of contemporary green worldview. European Advances in Consumer Research, 1, 416-427.

Hall, C. M. (2011). Policy learning and policy failure in sustainable tourism governance: From first- and second-order to third order change? Journal of Sustainable Tourism. 19, 649-671. 
Han, H., Hsu, L., \& Lee, J. (2009). Empirical investigation of the roles of attitudes toward green behaviors, overall image, gender, and age in hotel customers' ecofriendly decision-making process. International Journal of Hospitality Management, 28(4), 519-528.

Han, H., Hsu, L. J., Lee, J., \& Sheu, C. (2011). Are lodging customers ready to go green? An examination of attitudes, demographics, and eco-friendly intentions. International Journal of Hospitality Management, 30(2), 345-355.

Han, H., Hsu, L., \& Sheu, C. (2010). Application of the theory of planned behavior to green hotel choice: Testing the effect of environmental friendly activities. Tourism Management, 31(3), 325-334.

Han, H., \& Ryu, K. (2006). Moderating role of personal characteristics in forming restaurant customers' behavioral intentions: An upscale restaurant setting. Journal of Hospitality and Leisure Marketing, 15(4), 25-53.

Howell, S. E., \& Laska, L. B. (1992). The changing face of the environmental coalition: A research note. Environment and Behavior, 24, 134-144.

Im, S., Bayus, B. I., \& Mason, C. H. (2003). An empirical study of innate consumer innovativeness, personal characteristics, and new-product adoption behavior. Journal of the Academy of Marketing Science, 31(1), 61-73.

Jainchill, J. (2009, September 28). Cruise association sues Alaska, claiming \$46 head tax is illegal. Travel Weekly. Retrieved from http://www.travelweekly.com/CruiseTravel/Cruise-association-sues-Alaska,-claiming-\$46-head-tax-is-illegal/

Jensen, A., \& Mogensen, B. (2000). Effects, ecology and economy. Environmental aspects of dredging - Guide No. 6. International Association of Dredging Companies and Central Dredging Association, 119.

Johnson, D. (2002). Environmentally sustainable cruise tourism: A reality check. Marine Policy, 26(4), 261-270.

Kashima, Y., Paladino, A., \& Margetts, E. A. (2014). Environmentalist identity and environmental striving. Journal of Environmental Psychology, 38, 64-75.

Khan, S., Shahnaz, M., Jehan, N., Rehman, S., Shah, M. T., \& Din, I. (2013). Drinking water quality and human health risk in Charsadda District, Pakistan. Journal of Cleaner Production, 60(0), 93-101.

Kilbourne, W. E., \& Beckmann, S. C. (1998). Review and critical assessment of research on marketing and the environment. J Mark Manage, 14(6), 513-532. 
Kim, Y., \& Han, H. (2010). An investigation of green hotel customers' decision formation: Developing an extended model of the theory of planned behavior. International Journal of Hospitality Management, 29(4), 659-668.

Kim, Y. J., Palakurthi, R., \& Hancer, M. (2012). The environmentally friendly programs in hotels and customers' intention to stay: An online survey approach. International Journal of Hospitality \& Tourism Administration, 13(3), 195-214.

King, L. (2014, May 21). Port Canaveral dredging edges closer to reality. Florida Today. Retrieved from http://www.floridatoday.com/story/money/business/2014/05/21/port-canaveraldredging-edges-closer-reality/9397205/

Kirk, D. (1995). Environmental management in hotels. International Journal of Contemporary Hospitality Management, 7(6), 3-8.

Klein, R. A. (2005). Cruise ship squeeze: The new pirates of the seven seas. New Society Publisher, Canada

Klein, R. A. (2011). Responsible cruise tourism: Issues of cruise tourism and sustainability. Journal of Hospitality and Tourism Management, 18(1), 107-116.

Klein, R. A. (2013). Reported cruise industry spending on lobbying the US Congress, 1997 - 2013. Retrieved from http://www.cruisejunkie.com/lobbying.pdf

Ko, T. G. (2005). Development of a tourism sustainability assessment procedure: A conceptual approach. Tourism Management, 26(3), 431-445.

Lafferty, W. M., \& Langhelle, O. (1999). Sustainable development as concept and norm, towards sustainable development. In: Lafferty, W.M., Langhelle, O. (Eds.), On the Goals of Development - and the Conditions of Sustainability. MacMillan Press Ltd., London, pp. 1-29.

La Lopa, J. M., \& Day, J. (2011). Pilot study to assess the readiness of the tourism industry in Wales to change to sustainable tourism practices. Journal of Hospitality and Tourism Management. 18, 130-139.

Laroche, M., Bergeron, J., \& Barbaro-Forleo, G. (2001). Targeting consumers who are willing to pay more for environmentally friendly products. Journal of Consumer Marketing, 18(6), 503-520.

Larsen, S., Wolff, K., Marnburg, E., \& Øgaard, T. (2013). Belly full, purse closed: Cruise line passengers' expenditures. Tourism Management Perspectives, 6(0), 142-148. 
Laws and Regulations. (2014, March 27). State of Alaska. Retrieved June 8, 2014, from http://dec.alaska.gov/water/cruise_ships/Law_and_Regs/

Lehto, X. Y., O'Leary, J. T., \& Lee, G. (2001). Mature international travelers: An examination of gender and benefits. Journal of Hospitality and Leisure Marketing, 9, 53-72.

Lewis, R. R. (1976). Impact of dredging in the Tampa Bay estuary, 1876-1976. Timestressed Coastal Environments: Assessment and Future Action. The Coastal Society, Arlington, Virginia, 31-55.

Lewis, R. R., Durako, M. J., Moffler, M. D., \& Phillips, R. C. (1985). Seagrass meadows of Tampa Bay. Tampa Bay Area Scientific Information Symposium. Burgess Publishing Co., Minneapolis, 210-246.

Liddiard, M., Gladwin, D. J., Wege, D. C., \& Nelson-Smith, A. (1989). Impact of boulder-turning on shelter sea shores. School of Biological Sciences, University College of Swansea Report.

Li, J., Yu, N., Zhang, B., Jin, L., Li, M., Hu, M., . . Yu, H. (2014). Occurrence of organophosphate flame retardants in drinking water from china. Water Research, 54, 53-61.

Lovitt, R. (2013, May 1). Would your cruise have fewer problems if Americans ran it? NBC News. Retrieved from http://www.nbcnews.com/travel/would-your-cruisehave-fewer-problems-if-americans-ran-it-6C9657156

Luck, M., Maher, P., \& Stewart, E. (2010). Cruise tourism in polar regions. (1st ed.). London: Earthscan.

MacInnis-Ng, C. (2003). In situ stress monitoring of anthropogenic impacts on Zostera capricorni. Ph.D. thesis, Department of Environmental Sciences, University of Technology, Sydney

Mak, J., Sheehey, C., \& Toriki, S. (2010). The passenger vessel services act and America's cruise tourism industry. Research in Transportation Economics. 26(1), $18-26$.

Manaktola, K., \& Jauhari, V. (2007). Exploring consumer attitude and behavior towards green practices in the lodging industry in India. International Journal of Contemporary Hospitality Management. 19(5), 364-377.

McGee, B. (2013, January 8). Why are ships registered in foreign countries? USA Today. Retrieved from http://www.usatoday.com/story/travel/cruises/2012/12/11/whyare-cruise-ships-registered-in-foreign-countries/1760759/ 
McIntyre, R. P., Meloche, M.S., \& Lewis, S. I. (1993). National culture as a macro tool for environmental sensitivity segmentation. In Cravens, D. W. \& Dickson, P. R., AMA Summer Educators' Conference Proceedings. American Marketing Association, Chicago, 4, 153-159.

Mebratu, D. (1998). Sustainability and sustainable development: Historical and conceptual review. Environmental Impact Assessment Review, 18(6), 493-520.

Melia, M. (2009, March 1). Caribbean cruise ships dump garbage at sea. Associated Press. Retrieved from http://www.sfgate.com/news/article/Caribbean-cruiseships-dump-garbage-at-sea-3169729.php

Meyer, D. (2006). Caribbean tourism, local sourcing and enterprise development: Review of the literature. Pro Poor Tourism Working Paper 18. : Centre for Tourism and Cultural Change, Sheffield Hallam University

Millar, M., \& Baloglu, S. (2011). Hotel guests' preferences for green guest room attributes. Cornell Hospitality Quarterly, 52(3), 302-311.

Miller, A. (2002, January 1). Greed upon the oceans: Flag of convenience ships. Industrial Workers of the World.

Murray, T. J. (2005). The impact of cruise ship tourism on local economies. Proceedings of the 14th Biennial Coastal Zone Conference, Retrieved from http://www.csc.noaa.gov/cz/CZ05_Proceedings/pdf files/MurrayT.pdf

Myers, G. N. (2012, September 25). Jamaica unhappy with cruise pax spending. Travel Weekly. Retrieved from http://www.travelweekly.com/Cruise-Travel/Jamaicaunhappy-with-spending-levels-of-cruise-passengers/

National Ocean Service. (n.d.). What is dredging? National Oceanic and Atmospheric Administration. Retrieved June 7, 2014, from http://oceanservice.noaa.gov/facts/dredging.html

Ocean ranger program hiring information: Alaskans wanted. (2013, May 20). State of Alaska. Retrieved July 5, 2014, from http://www.dec.state.ak.us/water/cruise_ships/ocean_ranger.htm

Orams, M. (1999). Marine tourism. (1st ed.). London: Routledge.

P\&O Cruises. (n.d.). Our heritage: P\&O Cruises 175 year heritage. Retrieved February 27, 2014, from http:/www.pocruises.com/about-po-cruises/175-years-of-heritage/

Pattullo, P. (1996). Last resorts: The costs of tourism in the Caribbean. Cassell. 
Pirotta, E., Laesser, B. E., Hardaker, A., Riddoch, N., Marcoux, M., \& Lusseau, D. (2013). Dredging displaces bottlenose dolphins from an urbanised foraging patch. Marine Pollution Bulletin, 74(1), 396-402.

Profile of the U.S. cruise industry. (n.d.). Retrieved February 1, 2014, from http://www.cruising.org/pressroom-research/cruise-industry-source-book/profileus-cruise-industry

Ramos, S. J. (2014). Planning for competitive port expansion on the U.S. eastern seaboard: The case of the savannah harbor expansion project. Journal of Transport Geography, 36(0), 32-41.

Ramus, C. A., \& Montiel, I. (2005). When are corporate environmental policies a form of greenwashing? Business Society, 44, 377-414.

Rapaglia, J., Zaggia, L., Ricklefs, K., Gelinas, M., \& Bokuniewicz, H. (2011). Characteristics of ships' depression waves and associated sediment resuspension in Venice Lagoon, Italy. Journal of Marine Systems, 85(1-2), 45-56.

Resource Development Council. (n.d.). Alaska's tourism industry. Retrieved June 8, 2014, from http://www.akrdc.org/issues/tourism/overview.html

Royal Caribbean International. (n.d.). Things to do onboard. Retrieved February 27, 2014, from

http://www.royalcaribbean.com/findacruise/experiencetypes/category.do?pagena me $=$ onboard_cat_things_to_do

Roberts, J. A. (1996). Green consumers in the 1990s: Profile and implications for advertising. Journal of Business Research, 36, 217-231.

Ruhanen, L. (2008). Progressing the sustainability debate: A knowledge management approach to sustainable tourism planning. Current Issues in Tourism. 11, 429-455.

Schumacher, E. F. (1973). Small is beautiful: Economics as if people mattered. London: Blond \& Briggs.

Semeniuk, C., Speers-Roesch, B., \& Rothley K. (2007). Using fatty acid profile analysis as an ecological indicator in the management of tourist impacts on marine wildlife: A case of stingray-feeding in the Caribbean. Environmental Management, 40, 665-667.

Semeniuk, C., Bourgeon, S., Smith, S., \& Rothley, K. (2009). Hematological differences between stingrays at tourists and non-visited sites suggest physiological costs of wildlife tourism. Biological Conservation, 142, 1818-1829. 
Shackley, M. (1998). Stingray city - managing the impact of underwater tourism in the Cayman Islands. Journal of Sustainable Tourism, 6, 328-338.

Sharife, K. (2010). Flying a questionable flag. World Policy Journal, 27(4), 111-118.

Showker, K. (2010). The unofficial guide to cruises. (14th ed.). Hoboken: John Wiley \& Sons, Inc.

Silversea. (n.d.). Expedition cruises. Retrieved February 27, 2014, from http://www.silversea.com/expeditions/

Sloan, G. (2013, January 30). Princess cruises fined for discharge in Glacier Bay. USA Today. Retrieved from http://www.usatoday.com/story/cruiselog/2013/01/30/princess-cruises-glacierbay-fine/1876607/

Smit, W., \& Parnell, S. (2012). Urban sustainability and human health: An African perspective. Current Opinion in Environmental Sustainability, 4(4), 443-450.

Squires, N. (2014, March 18). Venice ordered to allow big cruise ships back into lagoon. The Telegraph. Retrieved from http://www.telegraph.co.uk/news/worldnews/europe/italy/10706026/Veniceordered-to-allow-big-cruise-ships-back-into-lagoon.html

Standish, D. (2012). Venice in environmental peril? Lanham: University Press of America.

Stanton, W. J., Etzel, M. J., and Walker, B. J. (1994). Fundamental of marketing. (10 ${ }^{\text {th }}$ ed.), USA: McGraw-Hill, Inc.

Sun, X., Jiao, Y., \& Tian, P. (2011). Marketing research and revenue optimization for the cruise industry: A concise review. International Journal of Hospitality Management, 30(3), 746-755.

Toh, R. S., \& Sock-Yong Phang. (1993). Quasi-flag of convenience shipping: The wave of the future. Transportation Journal (American Society of Transportation \& Logistics Inc), 33(2), 31-39.

Torgler, B., Garcia-Valiñas, M. A., \& Macintyre, A. (2008). Differences in preferences towards the environment: The impact of a gender, age and parental effect. Retrieved from http://ageconsearch.umn.edu/bitstream/6371/2/080018.pdf 
Torres-Delgado, A., \& López Palomeque, F. (2012). The growth and spread of the concept of sustainable tourism: The contribution of institutional initiatives to tourism policy. Tourism Management Perspectives, 4(0), 1-10.

Tre, M. (2011, March 14). A look at cruise ship registry. Retrieved June 25, 2013, from http://www.cybercruises.com/CM_Mar14-A-Look-At-Cruise-Ship-Registry.htm

Tyrväinen, L., Uusitalo, M., Silvennoinen, H., \& Hasu, E. (2014). Towards sustainable growth in nature-based tourism destinations: Clients' views of land use options in Finnish Lapland. Landscape and Urban Planning, 122(0), 1-15.

United Nations Environment Programme. (n.d., a). Negative economic impacts of tourism. Retrieved April 3, 2014, from http://www.unep.org/resourceefficiency/Business/SectoralActivities/Tourism/Fact sandFiguresaboutTourism/ImpactsofTourism/EconomicImpactsofTourism/Negati veEconomicImpactsofTourism/tabid/78784/Default.aspx

United Nations Environment Programme. (n.d., b). Tourism's three main impact areas. Retrieved March 10, 2014, from http://www.unep.org/resourceefficiency/Business/SectoralActivities/Tourism/Fact sandFiguresaboutTourism/ImpactsofTourism/EnvironmentalImpacts/TourismsThr eeMainImpactAreas/tabid/78776/Default.aspx

United States Congress. (2013). Clean cruise ship act of 2013 (S. 1359). Retrieved from 113th Congress website: http://www.gpo.gov/fdsys/pkg/BILLS113s1359is/pdf/BILLS-113s1359is.pdf

Vanhove, N. (2011). 8 - the economic impact of tourism. In N. Vanhove (Ed.), The economics of tourism destinations (second edition) (pp. 223-279). London: Elsevier.

Vlosky, D. A., \& Vlosky, R. P. (1999). Exploring age-related environmental attitudes in the context of wood product certification. Louisiana State University Agricultural Center.

Vora, S. (2007, June 25). Business travelers go green. Forbes. Retrieved from http://www.forbes.com/2007/06/21/business-travel-environment-forbeslifetravel_cx_sv_0622green.html

Vos, R. O. (2007). Defining sustainability: A conceptual orientation. Journal of Chemical Technology and Biotechnology. 82, 334-339.

Walters, G. C., \& Bergill, B. J. (1989). Consumer behavior: A decision making approach. USA: South-Western publishing Co. 
Webster, C., \& Ivanov, S. (2014). Transforming competitiveness into economic benefits: Does tourism stimulate economic growth in more competitive destinations? Tourism Management, 40(0), 137-140.

Wood, R. E. (2004). Cruise ships: Deterritorialized destinations. In L. Lumsdon \& S. Page (Eds.), Tourism and transport: Issues and agenda for the new millennium (1st ed.). Oxford: Elsevier Ltd.

World Commission on Environment and Development. (1987). Our common future. Oxford: Oxford University Press.

World Tourism Organization. (2014). World tourism barometer. Retrieved from http://dtxtq4w60xqpw.cloudfront.net/sites/all/files/pdf/unwto_barom14_01_jan_e xcerpt.pdf

World Tourism Organization. (n.d., a). Definition: Sustainable development of tourism. Retrieved March 31, 2014, from http://sdt.unwto.org/en/content/about-us-5

World Tourism Organization. (n.d., b). Historical perspective of world tourism. Retrieved March 10, 2014, form http://www.unwto.org/facts/menu.html

World Tourism Organization. (n.d., c). Tourism 2020 vision. Retrieved March 10, 2014, form http://www.unwto.org/facts/menu.html

World Tourism Organization. (n.d., d). Why tourism? Retrieved March 10, 2014, from http://www2.unwto.org/en/content/why-tourism

Zelezny, L. C., Chua, P. P., \& Aldrich, C. (2000). Elaborating on gender differences in environmentalism. Journal of Social Issues, 56, 443-457.

Zimmer, M. R., Stafford, T. F., \& Stafford, M. R. (1994). Green issues: Dimensions of environmental concern. Journal of Business Research, 30(1), 63-74. 
APPENDICES 


\section{Appendix A. Consumer Perceptions Survey}

\begin{tabular}{|l|}
\hline A. Cruise Background: \\
\hline A1: How many times have you cruised? \\
\hline Have not cruised \\
\hline 1 time \\
\hline $2-4$ times \\
\hline $5-9$ times \\
\hline $10-14$ times \\
\hline $15-19$ times \\
\hline $20-24$ times \\
\hline $25-29$ times \\
\hline $30-34$ times \\
\hline $35+$ times \\
\hline
\end{tabular}

A2: What cruise line is your preferred line to sail?

A2b: (Respondent who has not cruised before: Which cruise line are you most interested to sail on for the first time?)

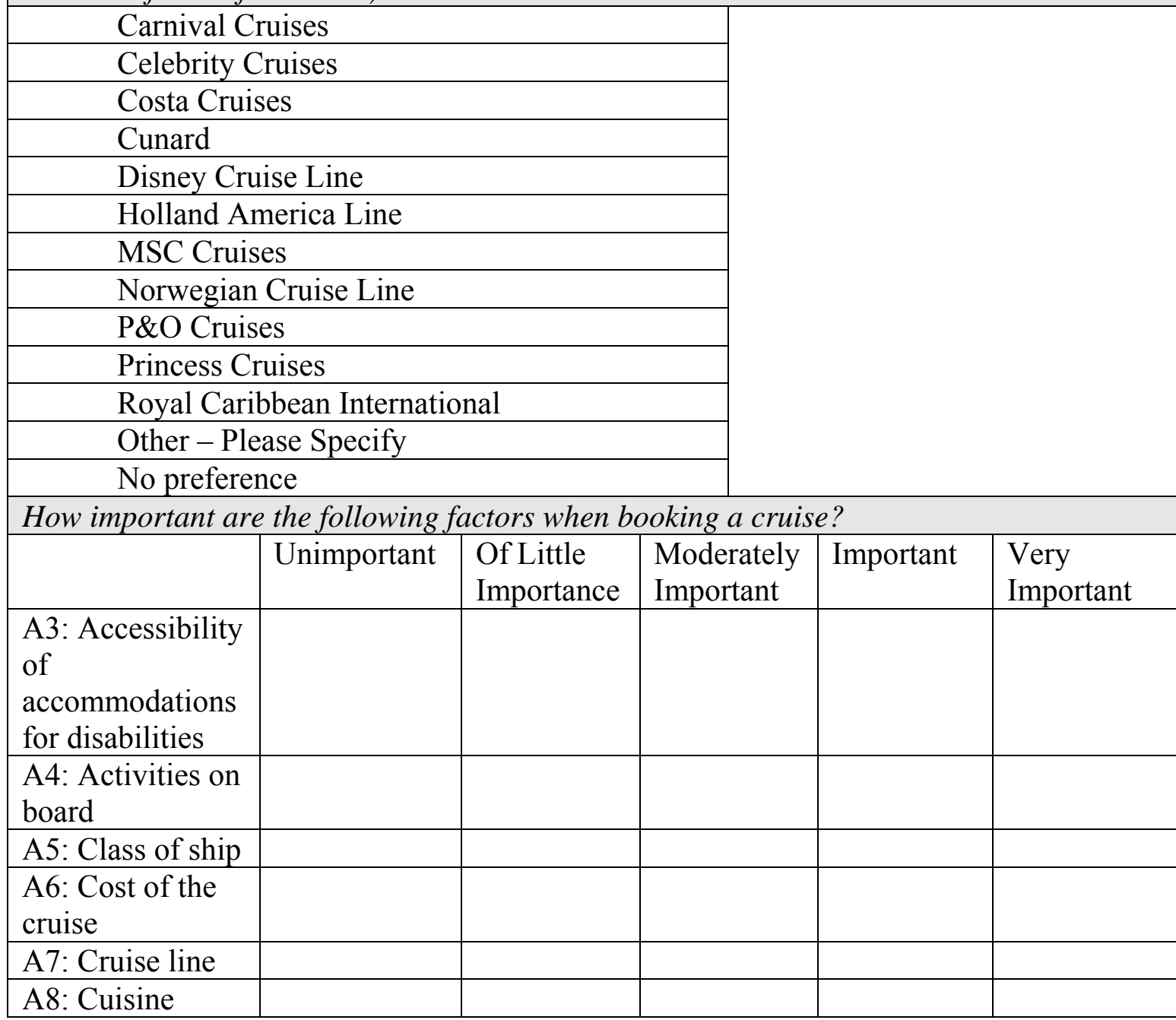




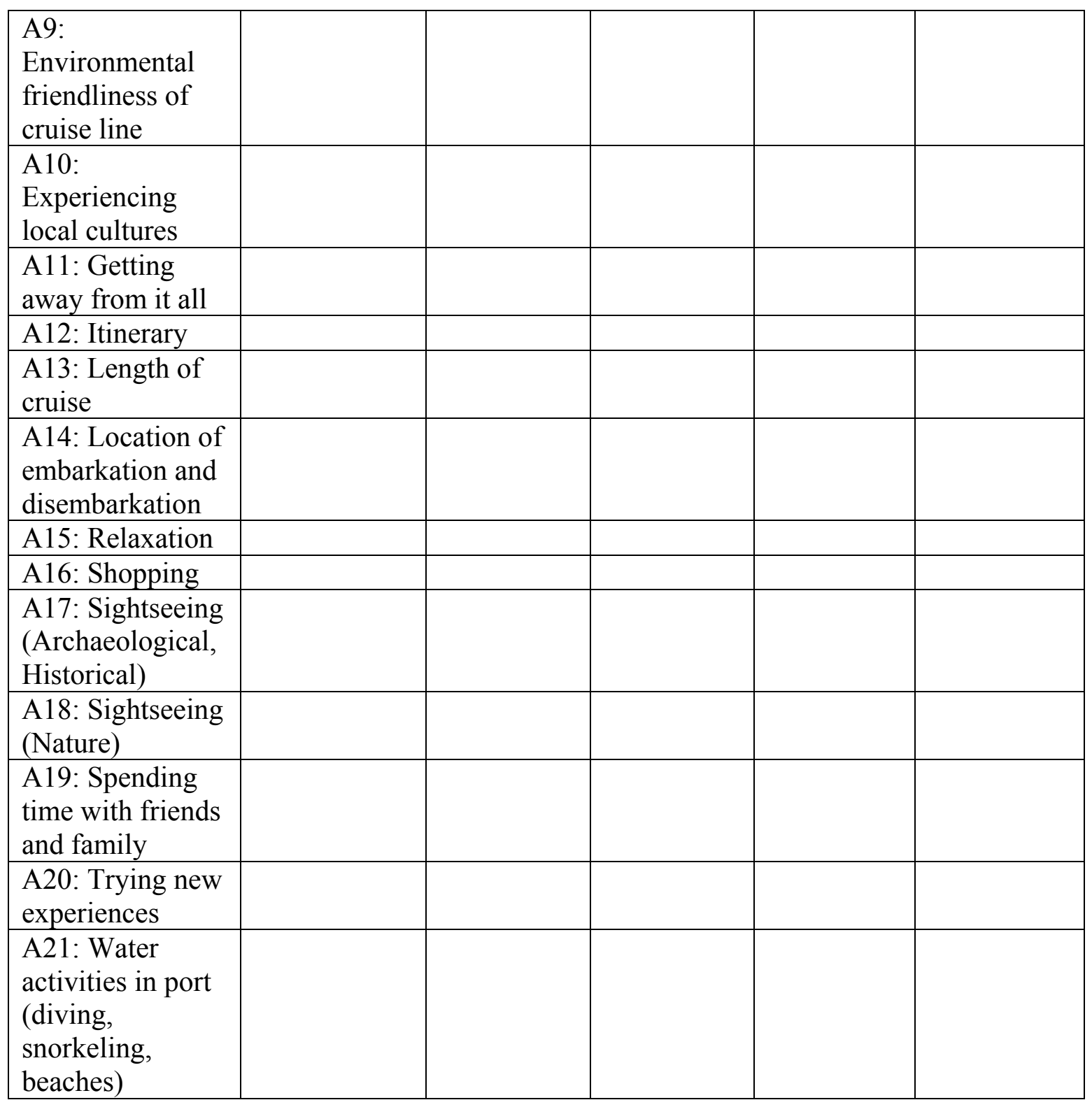

\section{B. Sustainability:}

B1: What does the idea of sustainability mean to you? (Check all that apply)

Purchasing and using local products

Conserving resources around me

Respecting native populations

Earning a living wage

Using environmentally friendly products

B2: Where do you feel each cruise line scores in sustainability from 1 to 10 ? With 1 being the lowest on sustainable practices and 10 being the highest with sustainable practices.

\begin{tabular}{l|llllllllllll} 
B2.1: Carnival Cruises & 1 & 2 & 3 & 4 & 5 & 6 & 7 & 8 & 9 & 10 & No Opinion \\
\hline
\end{tabular}




\begin{tabular}{|c|c|c|c|c|c|c|c|c|c|c|}
\hline B2.2: Celebrity Cruises & 12 & 3 & 4 & 5 & 6 & 7 & & 9 & 10 & No Opinion \\
\hline B2.3: Disney Cruise Line & 12 & 3 & 4 & 5 & 6 & 7 & 3 & 9 & 10 & No Opinion \\
\hline B2.4: Holland America Line & 12 & 3 & 4 & 5 & 6 & 7 & 3 & 9 & 10 & No Opinion \\
\hline B2.5: MSC Cruises & 1 & 3 & 4 & 5 & 6 & 7 & 3 & 9 & 10 & No Opinion \\
\hline B2.6: Norwegian Cruise Line & 1 & 3 & 4 & 5 & 6 & 7 & 3 & 9 & 10 & No Opinion \\
\hline B2.7: Princess Cruises & 1 & 3 & 4 & 5 & 6 & 7 & 3 & 9 & 10 & No Opinion \\
\hline $\begin{array}{l}\text { B2.8: Royal Caribbean } \\
\text { International }\end{array}$ & 2 & 3 & 4 & 5 & 6 & 7 & & 9 & 10 & No Opinion \\
\hline \multicolumn{11}{|c|}{ B3: Do you feel the cruise industry is sustainable? } \\
\hline \multicolumn{6}{|l|}{ No } & & & & & \\
\hline \multicolumn{6}{|l|}{ Yes } & & & & & \\
\hline No ( & & & & & & & & & & \\
\hline
\end{tabular}

\section{Sustainable Travel Consumer Behavior:}

Select the option that best describes your opinion

\begin{tabular}{|l|l|l|l|l|l|}
\hline $\begin{array}{l}\text { C1: When I travel } \\
\text { I try to stay at a } \\
\text { hotel that is } \\
\text { considered 'green' }\end{array}$ & $\begin{array}{l}\text { Strongly } \\
\text { Disagree }\end{array}$ & Disagree & $\begin{array}{c}\text { Neither } \\
\text { Agree nor } \\
\text { Disagree }\end{array}$ & Agree & $\begin{array}{c}\text { Strongly } \\
\text { Agree }\end{array}$ \\
\hline $\begin{array}{l}\text { C2: When I travel } \\
\text { I try to stay at a } \\
\text { hotel that is } \\
\text { locally owned } \\
\text { (local vendor } \\
\text { instead of large } \\
\text { chains) }\end{array}$ & & & & & \\
\hline $\begin{array}{l}\text { C3: When I travel } \\
\text { I prefer to stay at } \\
\text { chain hotels } \\
\text { (Hilton, Hyatt, }\end{array}$ & & & & & \\
$\begin{array}{l}\text { Intercontinental, } \\
\text { etc) }\end{array}$ & & & & & \\
\hline $\begin{array}{l}\text { C4: When I travel } \\
\text { I am willing to } \\
\text { reuse my towel or } \\
\text { bed linens }\end{array}$ & & & & & \\
\hline $\begin{array}{l}\text { C5: When I travel } \\
\text { I try to eat at } \\
\text { restaurants that } \\
\text { are familiar (chain } \\
\text { restaurants) }\end{array}$ & & & & & \\
\hline
\end{tabular}




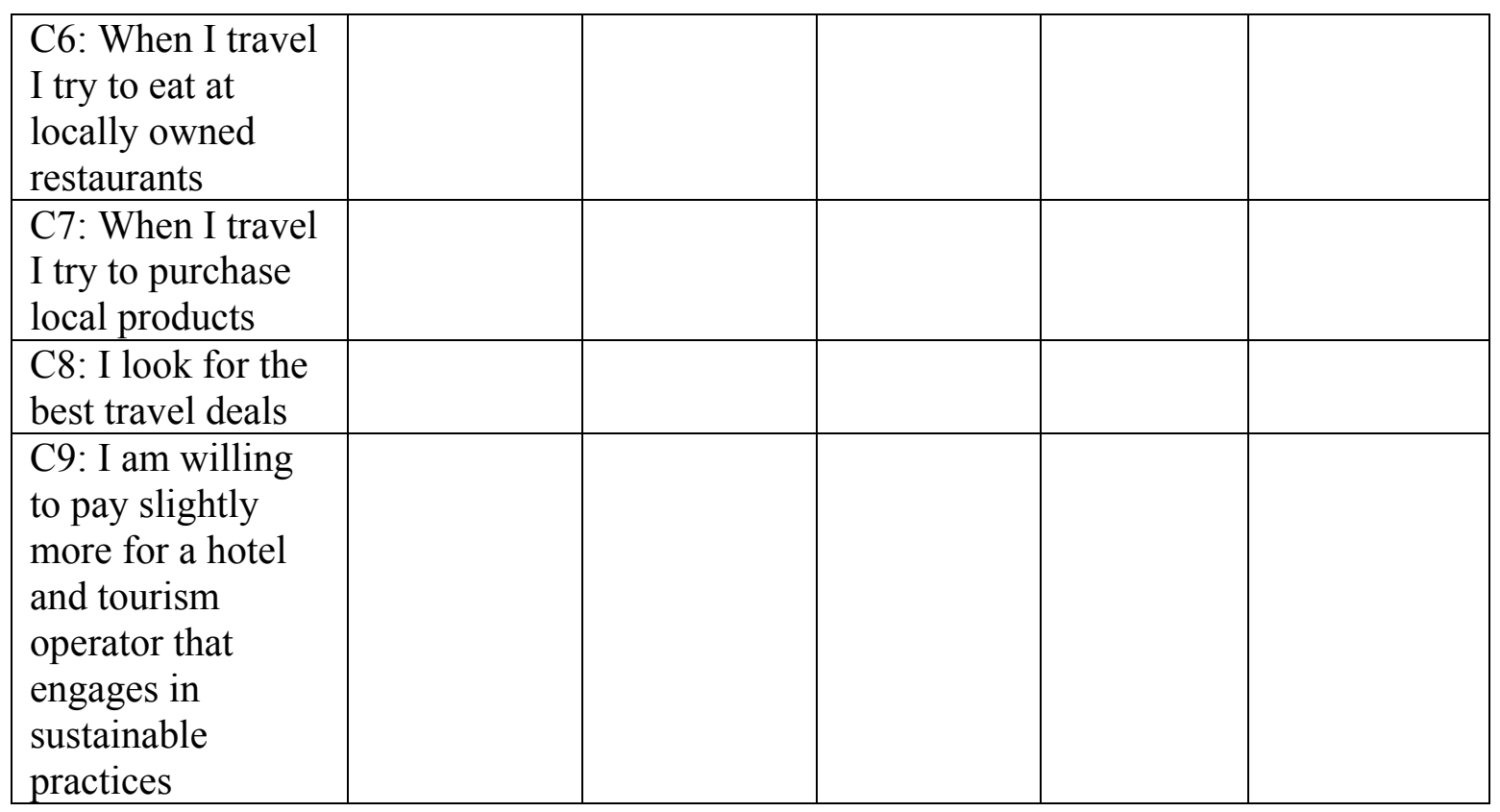

\section{Cruise Line Sustainability:}

How important are the following sustainable factors when choosing a cruise line?

\begin{tabular}{|c|c|c|c|c|c|}
\hline & Unimportant & $\begin{array}{c}\text { Of Little } \\
\text { Importance }\end{array}$ & $\begin{array}{l}\text { Moderately } \\
\text { Important }\end{array}$ & Important & $\begin{array}{c}\text { Very } \\
\text { Important }\end{array}$ \\
\hline \multicolumn{6}{|c|}{ Environmental Sustainability } \\
\hline $\begin{array}{l}\text { D1: Green and } \\
\text { Sustainable } \\
\text { Certifications } \\
\text { (Green Globe, } \\
\text { STEP, etc.) }\end{array}$ & & & & & \\
\hline $\begin{array}{l}\text { D2: Access to } \\
\text { alternative modes } \\
\text { of transportation } \\
\text { in ports (bicycle } \\
\text { rentals, public } \\
\text { transportation) }\end{array}$ & & & & & \\
\hline $\begin{array}{l}\text { D3: Use of } \\
\text { renewable } \\
\text { materials and } \\
\text { finishes in cabins } \\
\text { and public spaces }\end{array}$ & & & & & \\
\hline $\begin{array}{l}\text { D4: Room card } \\
\text { reader for } \\
\text { passengers to } \\
\text { insert their cruise } \\
\text { cards when } \\
\text { entering a cabin to }\end{array}$ & & & & & \\
\hline
\end{tabular}




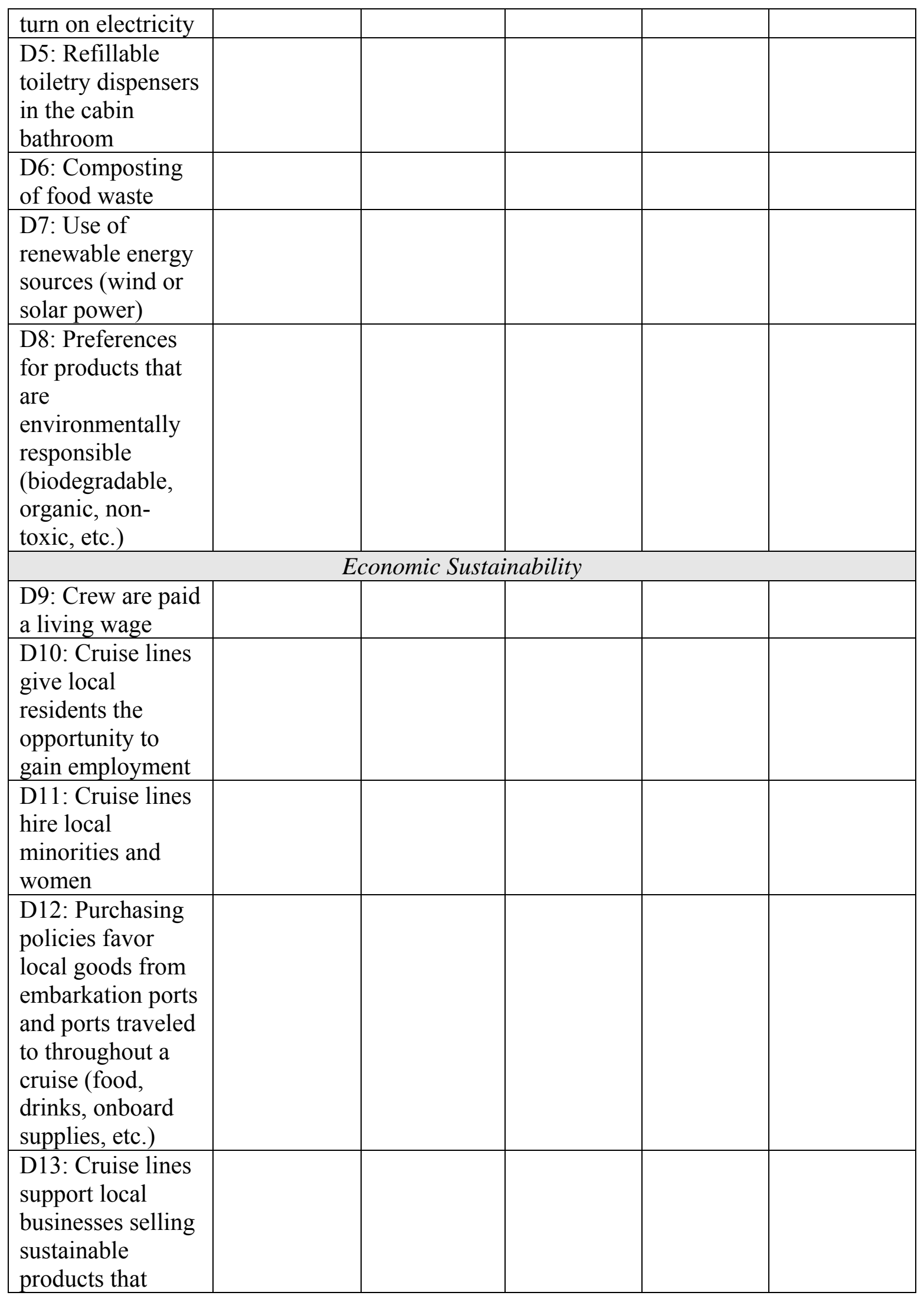




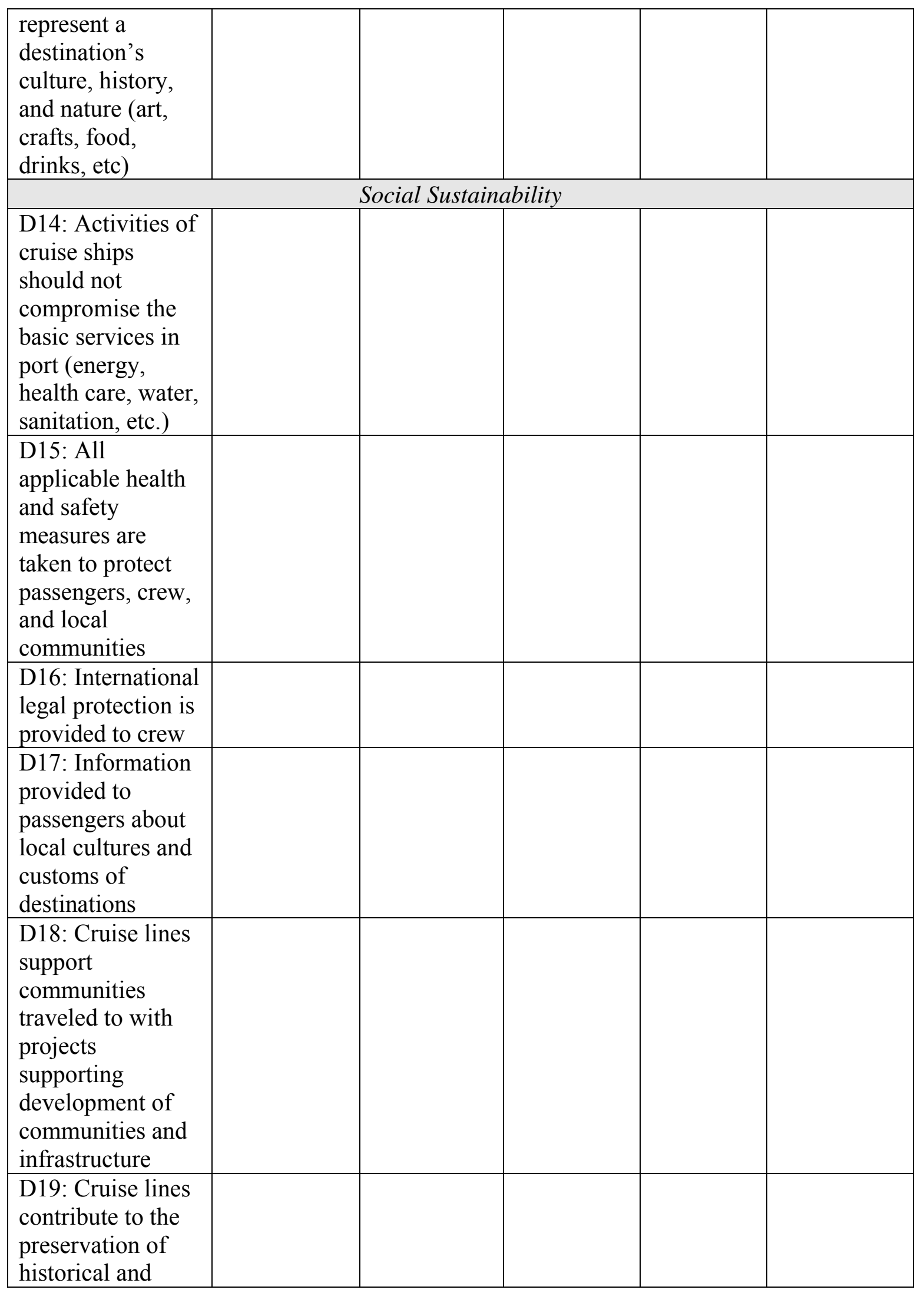




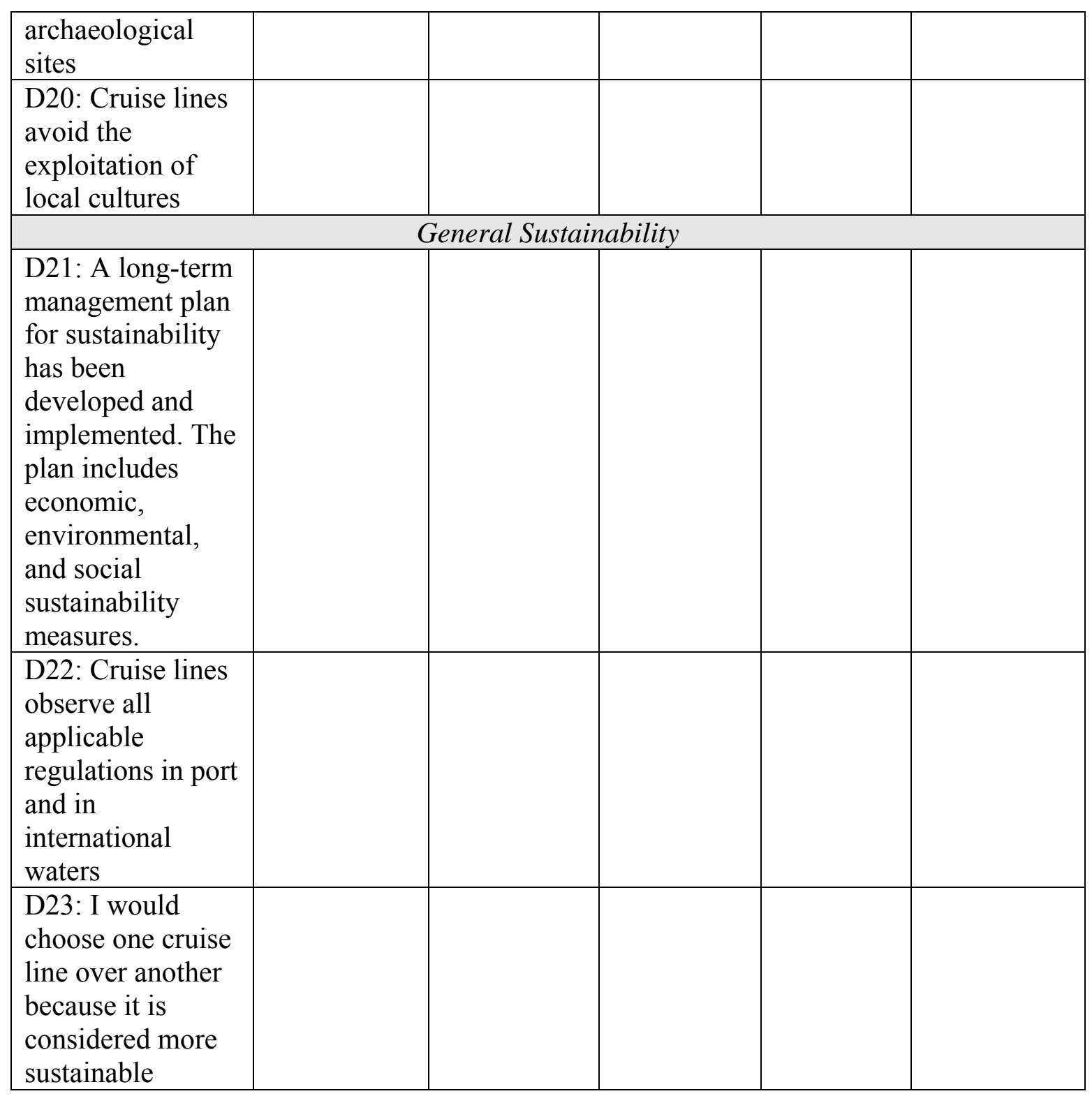

\section{E. Demographics:}

E1: Gender

\begin{tabular}{|c|c|}
\hline Male & \\
\cline { 1 - 2 } Female & \\
\hline Prefer not to answer & \\
\hline $18-25$ & \\
\hline $26-35$ & \\
\hline $36-45$ & \\
\hline $46-55$ & \\
\hline $55-65$ & \\
\hline
\end{tabular}




\begin{tabular}{|c|c|}
\hline $66+$ & \\
\hline Prefer not to answer & \\
\hline \multicolumn{2}{|l|}{ E3: Ethnicity Origin (Race) } \\
\hline \multicolumn{2}{|l|}{ Caucasian / White } \\
\hline \multicolumn{2}{|l|}{ African American / Black } \\
\hline Hispanic / Latino / Spanish & \\
\hline Asian & \\
\hline Pacific Islander & \\
\hline American Indian / Alaska Native & \\
\hline Other & \\
\hline \multicolumn{2}{|l|}{ Prefer not to answer } \\
\hline \multicolumn{2}{|l|}{ E4: How would you categorize where you live? } \\
\hline $\begin{array}{l}\text { Rural } \\
\text { Suburban }\end{array}$ & \\
\hline Suburban & \\
\hline Urban & \\
\hline \multicolumn{2}{|l|}{ Prefer not to answer } \\
\hline \multicolumn{2}{|l|}{ E5: Average Annual Household Income } \\
\hline Less than $\$ 19,999$ & \\
\hline$\$ 20,000-\$ 39,999$ & \\
\hline$\$ 40,000-\$ 59,999$ & \\
\hline$\$ 60,000-\$ 79,999$ & \\
\hline$\$ 80,000-\$ 99,999$ & \\
\hline$\$ 100,000-\$ 149,999$ & \\
\hline$\$ 150,000$ or more & \\
\hline \multicolumn{2}{|l|}{ Prefer not to answer } \\
\hline \multicolumn{2}{|l|}{ E6: Highest Education Level Achieved } \\
\hline Some High School & \\
\hline High School / GED / High School Equivalent & \\
\hline Some College & \\
\hline & \\
\hline $\begin{array}{l}\text { Associates Degree } \\
\text { Bachelor's Degree }\end{array}$ & \\
\hline $\begin{array}{l}\text { Bachelor's Degree } \\
\text { Some Post Graduate }\end{array}$ & \\
\hline Graduate Degree & \\
\hline Professional Degree & \\
\hline Prefer not to answer & \\
\hline
\end{tabular}




\section{Appendix B. IRB Approval Letter}

\section{INTERNATIONAL \\ UNIVERSITY}

Office of Research Integrity

Research Compliance, MARC 270

Dr. Carolin Lusby

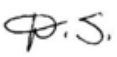

April 14, 2014

Consumer Perceptions of Sustainability in the Cruise Industry

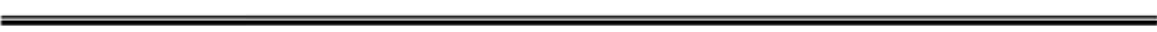

IRB-14-0063

$04 / 14 / 14$

102352

As a requirement of IRB Exemption you are required to:

Submit an Event Form and provide immediate

:

or discontinued.

Special N/A

Conditions:

For further information, you may visit the IRB website at http://research.fiu.edu/irb 